AperTO - Archivio Istituzionale Open Access dell'Università di Torino

\title{
Textbooks and Citizenship in modern and contemporary Europe
}

\section{This is a pre print version of the following article:}

Original Citation:

\section{Availability:}

This version is available http://hdl.handle.net/2318/1518070

since 2017-05-19T13:30:24Z

Publisher:

VERLAG PETER LANG

Published version:

DOI:http://dx.doi.org/10.3726/978-3-0351-0733-3

Terms of use:

Open Access

Anyone can freely access the full text of works made available as "Open Access". Works made available under a Creative Commons license can be used according to the terms and conditions of said license. Use of all other works requires consent of the right holder (author or publisher) if not exempted from copyright protection by the applicable law. 


\section{Index}

Paolo Bianchini, Roberto Sani

The History of Education between "Invented Archives"

and Actual Research

PAOLO BiAnCHINI

Didactics and Politics. The Birth of School Subjects in

Pre-Unification Piedmont (1814-1839)

GIANFRANCO BANDINI

Teaching Geography after the Unification of Italy.

A GIS Application for the History of Education

Ebubekir Ceylan

An Analysis of History of Turkish Education: Sources,

Pioneers and Approaches

Roberto Sani, Juri Meda, Anna Ascenzi and Marta Brunelli

Publishing for the School and Textbooks in the Fascist

Twenty-Year Period. From the Gentile Reform to the

End of The WWII (1923-1945)

LAMBROS VARELAS

Dictatorship and Literature Teaching in Modern Greek

Secondary Education (1936-1940)

Ana María Badanelli Rubio, Kira Mahamud Angulo

and Miguel Somoza Rodríguez

Gender Identities and Political Power in

Francoist School Textbooks (1940-1975) 
Doina-Olga Stefănescu, Alexandra Florea, Cristiana Petru and ANDRA Maria RoEscu

20 Years Of School Textbooks' History

in Romania (1989-2009)

\section{Giorgio Chiosso}

"Forming the Eminently Moral and Able Man"

The Reading Books after Unification 


\section{The History of Education Between "Invented Archives" and Actual Research}

The essays in this book are focused on the production and the use of textbooks in different countries and different periods of European history. By indicating some particularly important moments in the evolution of textbooks, they allow a better understanding of the educational history and of some other related topics: the history of school subjects mainly reconstructed through the contents offered to students at various levels of education; the educational and cultural policies that the states have continued through and what is still one of the most powerful means of training and orientation of public opinion: the school.

The common source to all the essays collected here is the scholarly publication. All authors have analyzed books, authors, publishers, users of manuals in limited contexts and moments in the history of education in different countries, in the attempt to study it through the real materials used daily in classes and not simply on teaching methods and pedagogical theories.

There are of course references to other documents, such as laws, regulations and educational programs and even iconography, useful elements for the studied context. As a matter of fact, for its own nature, the history of school and education in general, lies at the crossroads of different sources and historiographical interests: to reconstruct its phases it is certainly useful to have textbooks, programs, laws, and images, but it is also needed to know the training of teachers and the scientific debate on contemporary disciplines. Moreover, these issues may be approached through a qualitative or quantitative analysis.

In this sense, the book offers a broad overview of the different possibilities of investigation that textbooks represent, as they deal with different sources and heuristic methods. Some authors focus on the progressive definition of the contents of a single subject, through a qualitative analysis of several manuals, supported by the use of other sources. This approach 
allows us to know in depth subjects familiar to everyone, not just for historians, and perhaps because of it, little studied in their evolution in the curriculum.

This is the case of the Modern Greek literature textbooks studied by Lambros Varelas during the Metaxas dictatorship in Greece, which shows the apparent effort to use neutral textbooks with no political or ideological purposes in order to strengthen the power of the ruling government and to disseminate its principles.

The same idea is followed by Giorgio Chiosso who describes the evolution of textbooks in the primary and secondary Italian schools after the Unification of Italy, showing how textbooks have been used by the political and intellectual élites to forge Italian young people in loving and appreciating the new "unified country".

In this book, there are also scholars, such as Gianfranco Bandini and Paolo Bianchini, who study the textbooks from a quantitative perspective, by experimenting new research instruments for the history of education. In both cases, we are dealing with research and historiographical methods at their experimental level, which, however, show the concrete potentials offered by the computer programs that are easily applicable to subjects such as history. Bandini has interpreted data from geography textbooks used in Italian schools from 1874 to 1875 with a Geographic Information System (GIS), which allows a very refined research of data with historical and geographical information. By using geography as an object and research instrument at the same time, through GIS he analyses the strategies of adapting manuals by the instructors, showing how a textbook success was based upon its ability of addressing the teachers' patriotic feelings.

Bianchini, instead, has used the software for the "Automatic Lexical and Text treatment of Content Analysis" for a series of textbooks. This software, based on lexicology, has been used to analyze the contents of textbooks' titles published in Piedmont during the Restoration period. His essay focuses on the relationship between pedagogy and politics while using manuals as research instruments, in connection with the events and the protagonists of the historical time in order to underline the political and cultural strategies of the Kingdom of Sardinia.

In other essays, the manuals are considered as a means to understand the impact of the reforms on the school system and the didactic in general in a specific country. This is the case of Ebubekir Ceylan's research, as he used the analysis of History textbooks to map the fundamental phases of 
the school system and education in general in Turkey during the XIX and XX century.

Roberto Sani's, Juri Meda's, Anna Ascenzi's and Marta Brunelli's essays have the same objective while following the opposite path: by studying the laws and the regulations of the textbooks, they offer a new and original perspective on the school policy and on education in general during Fascism, by showing the effects on the educational publishing world at that time.

Other essays are focused on the contributions these manuals have provided to the national identity. Ana Maria Badanelli Rubio's, Kira Mahamud Angulo's and Miguel Somoza's research focuses on those female and male roles that were portrayed in the textbooks during Franco's dictatorship in Spain. The contents and the images analyzed in the essay highlight such a stereotyped ideal of a male and female figure to appear natural if not genetic even if in reality they were the results of definite ideological and political choices.

On the other hand, Doina-Olga Ştefãnescu and Alexandra Florea's article compares the textbooks written during Ceausescu's regime with those published after it, in regards to the interpretation of Romania's history. The resulting stories are so different among them as to affect the young students with different ideas of country and nation. Knowing that history is not neutral, the Romanian manuals show how historiography can heavily affect the identity of the single individual and the national one.

In this book, there are essays focused on several research methods and tools, together with essays on different periods and places in Europe, from Italy to Spain, Greece, Romania and Turkey: this last case is very interesting from the point of view of the European history of education for its diversified proposed perspective.

The heuristic approach of the essays in this book doesn't allow a complete reconstruction of the history of the school system in the different countries and of the single school subject. However, by analyzing the subject's contents and the manuals, this book contributes to examine in depth the subject in general together with its peculiar changes during the years.

It is also important to underline that the manuals' history can highlight the relevant changes which occurred in curricula, besides those that occurred in the publishing sector in Europe and in the surrounding countries. In this specific area, the manuals contribute to understand the critical moments, the continuity and the permanent aspects in the subjects and in 
the national and European culture which is a very old history, so for this reason it is not always easy to rebuild it with all its inner features.

As it is well known, didactic and politics influenced the school contents: we cannot dismiss, in fact, that the school subjects follow peculiar logic connected to the single individual formation but also the citizen one. For this reason, there has always been a gerarchy of the subjects in school which, however, has been changing. This is indicative of an understanding of the students' educational needs, seen as the future citizens. As a result, it cannot be considered neutral for the presence or the absence in the curricula of specific historical contents.

It is for this reason that all the essays investigate an important issue, i.e. the evolution of citizenship and the citizen concept in the modern and contemporary Europe. Grammar, history, geography, language and literature have been the instruments through which the students have gradually received the cultural basis of the Western civilization but they have also contributed to create the public opinion of the different countries.

Good and honest citizens, brave soldiers, smart entrepreneurs and managers have formed themselves in schools, by studying the deeds of the national army, their State frontiers and colonial policies. Acknowledging the importance of school and education in the building up of a national identity, besides the diffusion and success of ideologies and political trends, since the XIX century all the governments have used in a more or less successful way, education, textbooks, and school manuals as instruments to self promote themselves, censorship, control, and mold the public opinion and the future electing class.

It is important to acknowledge the above point, especially considering the historical period we are living in, where even if we are careful in not disseminating the young generations ideas of hate and prejudice, this is still not sufficient to form good citizens.

Paradoxically, what distinguishes the modern manuals from the old ones is the absence of a definite model of a citizen and of a man. We have been successful in eliminating - even if not totally - from the curricula and the textbooks, the references to superior genre, race, class, but we are still unable to form the $21^{\text {st }}$ century man, able to live in a globalised world in peace and with great opportunities, respectful of itself and the environment in order to leave a better place for the future generation. We have been able to erase the mistakes from the past, but we have not replaced them with new content and real alternatives. 
All the essays in this book were originally published in the website www.historyonline.eu, dedicated to the history of education, teaching and formation in Europe. The website was created thanks to funds from the Lifelong Learning Programme for 2008-2009 in partnership with six European countries - France, Germany, Greece, Italy, Romania, and Spain and a candidate country, Turkey. The project was to create what the American historian Roy Rosenzweig has called an "invented archive", including data from digital library and documents, but also samples of their use from historians. ${ }^{1}$

Each partner has contributed in building and implementing the website which is organized into three distinct sections. In the first section called Building History on Line, the historian will find all the preliminary tools necessary for his research, primary and secondary sources together with collections organized in data bases. In particular, he will find: a digital library of classics on education with more than 100 important works in full text on education and teaching produced by France, Germany, Great Britain, Greece, Italy, Romania, Spain and Turkey; data bases with different documents from textbooks to the laws on school publishing and iconographic collections. A search engine, called MOI, has been implemented and it allows performing multi searches in the data bases of Italian, Spanish and French textbooks. In this section, there is also a bibliography with more than 1000 sources among monographs and articles on the history of education, together with 500 links to webs and materials useful to the historical-education research.

The section Studying History on line presents instruments to study and how to use the sources by expert researchers and non experts. It is a sort of manual that provides methodological and procedural indications for a correct use of digital and regular sources. There are several types of sources and documents that could be useful for the researcher with real examples and links to useful websites.

The third section, Writing History on line, wants to experiment new and original modalities of writing history on line, in other words, paragraphs that the reader can verify and, in case, integrate and update directly

The quote is by R. Rosenzweig, The Road to Xanadu: Public and Private Pathways on the History Web, "Journal of American History", 88, 2, 2001, p.560<http://chnm. gmu.edu/resources/essays/roadtoxanadu.php $>$. See also G. Bandini-P. Bianchini, Fare storia in rete, Carocci, Firenze, 2007. 
on the sources reproduced in the section Building History on line or in other websites.

The essays present in this section and edited in this book have been written by connecting the reconstruction of history with its sources in a way to make the link between them more explicit and coherent. ${ }^{2}$ In reality, from an historical and hermeneutic point of view, the website (HOL) is not only a huge site with sources for the history on education and the historical research in general; it is above all a site where software and data bases are experimented in the analysis of the historical documents and the research modality and the innovative writing of history online.

The sources are collected, catalogued and organized for an easy access as the essays in Writing-History on line section show. One of the most important features of the website is, indeed, not only to facilitate and reproduce the sources and the historical documents, but also to offer new instruments for qualitative and quantitative analysis. By experimenting new collecting methods and interpretation of the historical documentation, it means to stimulate the elaboration of new forms of writing history online. The History on line user, even if he is not an expert researcher or an IT person, is provided with the instruments to connect the essays with the sources used to write them.

This modality of building the historical research has allowed us to get the pursued results: first of all, it has reinforced the relationship between historians and other professionals, especially librarians but also document experts, art experts, IT people, web managers and graphic experts, whose knowhow is linked to the planning and the making of high profile and high quality specialist sites. In addition to that, HOL has allowed us to keep the connection between the sources and their use by historians close. ${ }^{3}$

This is a way to help researchers and people interested in separating the most reliable history sites from the less useful ones. Everybody can now easily acknowledge that the web has a huge variety of historical ma-

2 To access the sources used in the essays here published, please go to: $<$ http://www. historyonline.eu/writinghistoryonline.aspx $>$.

3 On the difficulty of offering historiographical and web material, refer to S. A. Brennan-T. Mills Kelly, Why Collecting History Online is Web 1.5, March 2009, in <http://chnm.gmu.edu/essays-on-history-new-media/essays/?essayid=47>; D. J. Cohen, From Babel to Knowledge: Data Mining Large Digital Collections, in "D-Lib Magazine", Vol. 12, Number 3 (March, 2006), pp. 6-19, now also at: <http://chnm. gmu.edu/essays-on-history-new-media/essays/?essayid=40>. 
terial available. Many sites don't offer news or documents but they want to market alternative versions of history.

The essays collected here, in their digital and paper versions, want, instead, to contribute in enhancing our historical knowledge but also in elevating the web to the role it deserves, i.e. to transmit and amplify the knowledge and the critical thinking. 

PAOLO BIANCHINI

University of Turin

\title{
Didactics and Politics. The Birth of School Subjects in Pre-Unification Piedmont (1814-1839)
}

\begin{abstract}
The text will show how books for schools and education produced in Piedmont during the Restoration were affected not only by the educational strategies and educational reforms adopted by the Kingdom of Savoy, but even more so by the political choices of the State. The Savoy example may be used to assess how not only pedagogy, but also one of its highly technical branches, didactics, has political origins and intentions. For this the analysis will not only concern schools, and teaching practices, although it will use textbooks as the main way of assessing its arguments, but it will try to put them in context with the events and characters of the time, in order to identify links to the political and cultural strategies of the Kingdom of Sardinia.

The choice to consider the case of pre-unified Piedmont was made for two reasons: the first is that in the two decades immediately after the Restoration there was a strong desire to reorganise the State in the Kingdom of Sardinia, this was necessary to fulfil the government's intention to make people forget the period of French occupation which lasted from 1798 to 1814. Also a reactionary wave swept over the school and it underwent significant changes, even if deliberately disguised as a return to the past; the second reason is the weight that Savoy's scholastic model would have borne on unified Italy, to which the organisational and cultural baggage of the Piedmont school was added in 1861 .
\end{abstract}

\section{Introduction - The Lexicometric Approach and the History of Textbooks}

The period under consideration in this essay covers the years 1814 to 1839 . If the choice of the start date is rather obvious, since it coincides with the 
re-entry of the House of Savoy in their Kingdom, the final date has been chosen since, with the 1840 s, a significant change began to take place in both public opinion and the Piedmont government relative to education and schools. ${ }^{1}$ Indeed it was in 1839 that the Infant Schools Company became definitively operational and proceeded to play a fundamental role in the diffusion of a new way of understanding primary school education. No longer seen as merely offering assistance, it began to be conceived as a system that respected the cognitive modalities of pupils. The said Company played a considerable role in overcoming the resistance of conservatives and brought Ferranti Aporti to Turin, where he implemented the first method course for elementary school teachers.

The 1840s therefore represent the start of a new phase in the history of Piedmont's scholastic system, one that risks obscuring the work of previous decades, decades which had perhaps been less dynamic and successful but no less important, in this regard, in the history of Italian and Savoy school education.

The text books published in the 25 years between 1814 and 1839 , catalogued in Edisco, the databank for Italian school manuals, come to a total of $394 .^{2}$ These volumes were certainly used in schools and the number excludes those that were not specifically aimed at students, such as some catechisms, which were perhaps also used in classes, but were not published specifically for didactic use. The same holds for reading books relative to which it has not been possible to ascertain whether they were designed for teachers and/or students.

Certainly the sample we have chosen is highly significant though it does not claim to exhaustively include all text books produced in Piedmont in the decades immediately following the Congress of Vienna. ${ }^{3}$

The books in question will be subject to three different types of analysis. The first will be quantitative in nature, seeking to explore the trend in manuals production in Piedmont in the first decades of the 19th century, with particular attention focusing on the most representative authors,

A first version of this essay was published in P. Bianchini (editor), Le origini delle materie. Discipline, programmi e manuali scolastici in Italia, Torino, Sei, 2010.

$<$ http://www.reseducationis.it/edisco/>.

The survey focuses solely on texts produced in the Italian areas of the Kingdom of Sardinia, with the exclusion, therefore, of the area north of the Alps. In addition, manuals have not been considered that were printed by publishers resident in regions which came under Savoy control as a result of the Congress of Vienna e.g. the ancient Duchy of Genoa and part of Liguria. 
the evolution of disciplines and those publishers who were most closely attuned to the education market, in the light of the influence exercised by contemporary political events and the reform of the education system.

The second analysis will use TaLTaC $C^{2}$, software employed in the "Automatic lexical and textual treatment for Analysing the Contents of a collection of texts (corpus)". This treatment is aimed "at describing and interpreting the contents and/or some properties" of a corpus by means of a "lexicometric approach", applicable to all types of texts "expressed in a natural language, from documents to interviews, press summaries to messages, in accordance with the principles of textual statistics". ${ }^{4}$ This second typology of analysis will be used to investigate the evolution of literature aimed at schools through an analysis of titles, specifically exploring references to subjects, users, types of school and, more generally, verifying the transformations we are aware of in that period via didactical and education language.

The last type of analysis will be quintessentially qualitative in character and will focus on a limited number of manuals which stand out due to the originality of their subject matter, their target audience or the importance of their authors.

\section{The Context; the Savoy School after the Restoration}

Before Victor Emmanuel I returned to Turin on 17 may 1814, the order had reached Prospero Balbo, who had held the office of Chancellor during the Napoleonic period to close the University. The sovereign's decision was aimed, in truth, more at sanctioning the end of the revolutionary and Napoleonic experience, and resetting the events of the fifteen previous years and marking a new year zero in the history of the Piedmont school. The new government, however, didn't take long to notice the fact that it would not have been too difficult bring the Savoy school back to its situation prior to 1798 , and that, with the French gone again, there were very few subjects of the royal family who deserved to be punished for having worked with the invaders.

$4 \quad<$ http://www.taltac.it/it/index.shtml $>$. 
In any case, since he was borrowed to work for Napoleon, Balbo was removed, even if he laboriously managed to keep the Savoy school system almost unaltered and was sent away as Ambassador to the Court of Spain.

Victor Emmanuel I reorganised the Magistrate of the Reform, putting the elderly Gioacchino Adami di Cavagliano at its head, who very quickly died and was replaced in the same year by Gian Carlo Brignole, who had no experience in the field, but who belonged to the Amicizia cattolica [Catholic Friendship] of Turin, a secret society, based on the model of the Aa Jesuits, who appeared in Piedmont at the end of 1700s and then spread throughout Europe, focussed on re-capturing the people, and the government for the Catholic religion. A considerable weight inside the Magistrate from the start was the censor Giambattista Viotti, he was also a member of the Amicizia cattolica and a great supporter of the Jesuits.

Among the other members of the Magistrate was the decisive and straightforward figure of Gian Francesco Galeani Napione, a man faithful to Savoy and a promoter in the past of some important cultural initiatives, as the author of Dell'uso e dei pregi della lingua italiana (1791), in which claimed the exclusive use of Italian in Piedmont, and then Del modo di riordinare la regia Università degli studi (1799), with which, during the brief Austro-Russian occupation (1798-99), he had tried to guide the choice of the government in the educational field.

The few measures the Savoy school system underwent between 1814 and the 1818, all eminently reactionary, had a purpose: in the first place, the Costituzioni per l'Università of 1772 came into existence, including the Istruzione per insegnare by Goffredo Franzini, a sort of Rosetta stone for didactics, which contained the Piedmont rules that teachers were to adopt in their classes. Therefore, the licée was closed, a Napoleonic institution for excellence, which returned to being one of the two colleges of Turin, entrusted moreover to the Jesuits, who had lost the College of Nobles, which closed in 1773. Finally, elementary schools in Latin were legalised again, which were cast away by both the revolutionary and Napoleonic governments, both of which had tried to replace them with schools in the vernacular, accessible to children of all social classes.

The effects of the restrictive policy introduced by the restored Kingdom of Sardinia were felt in terms of the quantity and quality of manuals produced. A few years later, the Latinist, Vallauri, declared that "no province in Italy had books intended for use in schools that were as incorrect or badly printed as those in Piedmont". His evaluation appears to be 
confirmed by an official report in 1831 which stated that the texts "for the Royal Schools" were "full of errors and appallingly printed, on extremely poor quality paper". 5

Between 1814 and 1817 only 18 of the 393 texts produced in the period under examination were printed (equal to only $4.5 \%$ ). The Royal Printing Press published five, followed immediately by the printer, Pietro Barbié of Carmagnola, whose presses printed a total of four scholastic texts, and by Giuseppe Pomba, who printed a further three works. ${ }^{6}$

Barbié and Pomba had started their activity in the scholastic market back in the years prior to the French Revolution and had continued their involvement during the French period of occupation. It was therefore inevitable that they re-proposed manuals that were well known to the public and which had enjoyed considerable success. Moreover, the Royal Printing House's monopoly held only for books produced directly at the initiative of the Magistracy of Reform, a fact that permitted ample space for the involvement of printers interested in the formal and non formal education sector. And a significant number of publishers duly turned their attention, in some cases to an enormous degree, to the education market.

Indeed, between 1814 and 1839, the market share of the Royal Printing House fell significantly. Although it is true that during the period in question the Royal Printing House was the one publisher which, among all Piedmont printers, produced the largest number of books (70, equal to $17.8 \%$ ), it is also true that, as we will see below, over the years the impact of the other printers grew dramatically. In other words, the texts made available to Piedmont teachers and pupils constantly increased, while the production levels of the Royal Printing House remained stable, with the latter therefore in effect losing large sections of the market.

\footnotetext{
5 Both citations are taken from E. Soave, L'industria tipografica in Piemonte. Dall'inizio del XVIII secolo allo Statuto Albertino, Torino, Gribaudi, 1976, p. 44 and 135.

6 Many of the printers in the essay are mentioned in G. Chiosso (editor), TESEO, Tipografi e editori scolastico-educativi dell'Ottocento, Editrice Bibliografica, Milano, 2003. See this text for more detailed information concerning their overall history and production.
} 


\section{The Restoration in Didactics}

There was also a return to the past in textbooks. Used books were immediately removed from the market, of which there had been two main types until that time:

1. Books produced in Piedmont during the brief revolutionary period, between 1798, when Savoy were forced to leave Turin for Sardinia, and 1803, when Napoleon imposed an organic law to standardise the schooling system and content on all the countries that comprised the Empire. So textbooks by Girolamo Rostagni, Gaspare Morardo and above all the Primo and the Secondo libro by Giambattista Somis disappeared, the first school texts written in Piedmont based on the normal method. Books published in the Republican period that contained more or less explicit praise of the Revolution and the Republic could not be accepted for that reason within the school of a monarchy that was doing its utmost to make people forget the recent past. An eloquent example of how politics was present in the censored textbooks in 1814 is appears in Nuova introduzione alla geografia per uso delle scuole della XXVII Divisione militare by Girolamo Rostagni. Wnen reviewing the various European countries, the professor from Piedmont presented France as the country of the "straordinaria rivoluzione di cui noi tutti siam testimoni" [extraordinary revolution of which we are all witnesses]. ${ }^{7}$ It should be noted that Rostagni's textbook had already been censored at the time of its first edition, in 1803, when the Council of Education had ordered the removal of references to recent French history, to avoid incurring the wrath of Napoleon, who had just taken power, was seeking to appease France.

2. Books produced in France, as well as in French, such as those by Domergue, Wailli, Mantelle, Thouret, Rabaut, introduced by Napoleon, but also some classics, had always been used in Piedmont and which was traditionally bilingual, such as those by Fénélon, Rollin and La Fontaine. If the first ones were guilty of having been commissioned by Bonaparte for the schools of the Empire, the second ones were too dependent on French culture, against which the Savoy

G. Rostagni Nuova introduzione alla geografia, per uso delle scuole della XXVII Divisione militare, Torino Felice Buzan, fiorile anno X, p. 123. 
government was fighting a fierce battle. Actually from 1798, Piedmont had been annexed to France and as such the Republican governments, as Napoleon had tried to make the Piedmont people more like the French.

Which books replaced the texts used in the French era? Of course there was no time to complete and publish new textbooks. For this reason, they resorted to existing books that had been used in Piedmont schools before the arrival of the Revolution. It was a de facto restoration, as it was led by the effective and urgent need that only the books of the past could offer.

For this reason Piedmont students again started to study the texts that their fathers and sometimes even their grandfathers had already used:

- the Latin textbooks of Charles François Lhomond (Epitome historiae sacrae, Degli uomini illustri romani) and Oliver Goldsmith (Compendio della storia romana e della storia greca);

- more innovative scholarly texts produced in Piedmont in the last few years of the 1700s, in particular by Giuseppe Antonio Gallerone (Precetti scelti da' più valenti autori intorno all'abbellir il discorso, e all'esercitar lo stile) and Giuseppe Frencia (La declinazione italiana dei nomi e dei verbi, Brevi insegnamenti grammaticali), which, unlike those by Rostagni and Morardo, who were already also authors of innovative texts, had not complied so openly with the revolution. Those texts, which had represented a significant innovation in education in Piedmont at the end of the 1700s, were now largely surpassed. Their reintroduction in schools contributed to the approved return of the Savoy school system to a past that everyone now knew to be distant, but that was now proposed by the restored government of Savoy as the one safe harbour after the revolutionary storm.

\section{The Various Attempts at Moderate Reform (1818-1821)}

In reality, more lucid conservatives were aware that proceeding with a comprehensive reform of the Piedmont school system was now inevitable. The most convinced were Galeani Napione and Balbo. Galeani Napione worked towards this from 1814, even if cautiously, since the climate was 
not particularly favourable to reform measures. Since Balbo remained in Spain as an ambassador, he could only work marginally on operations of reflection and gathering material. Then in 1818 he was recalled to Piedmont, to hold the office of Magistrate of the Reform, in place of Brignole, and at that point work was able to proceed at greater speed.

The two had of a series of effective co-workers, the most active of which was Giuseppe Anselmi, who had been made to transfer from the College of Casale to the Royal Academy of Turin, thus offering a broader margin for manoeuvre. How do we explain the importance of Anselmi in the reform strategy of Balbo and Galeani Napione?

Anselmi had always called for an overall reform of the Piedmont school system: in 1803, on the occasion of the adoption of the law of reform with which Napoleon had tried to give a new structure to the education of the Empire, including Piedmont, Anselmi had published a Corso d'istruzione analogo al Decreto degli 11 fiorile anno $X^{8}$ The Corso proposed to perfect and to make the legal requirements applicable, adapting them to the Piedmont situation.

In 1807, while printing textbooks for all the orders of school, he published an ode All'Invitto Imperatore e Re Napoleone $I ;{ }^{9}$ then in 1814 , he turned to Balbo, this time testing the water informally, first in 1817 by printing another ode: De prospero Balbo, reduce ex Hispania legatione. ${ }^{10}$

In the period in which he worked with the men at the heads of the Magistrate of the Reform, Anselmi served as a collector of materials that colleagues went around collecting in Italy and abroad, or rather textbooks, study plans, regulations and designs. He had the task of analysing them beforehand, selecting them and summarising them, in order to make them easily accessible to the group of people who were working with Balbo and Galeani Napione. ${ }^{11}$ For this reason, Anselmi had extensive correspondence

8 G. Anselmi, Corso d'istruzione analogo al Decreto degli 11 fiorile anno X, Torino, Stamperia Nazionale, 1803.

9 G. Anselmi, All'Invitto Imperatore e Re Napoleone I. Canzone sullo stato d'Europa in fine dell'anno 1806, Casale, stamperia Paolo Corrado, 1807.

10 G. Anselmi, De prospero Balbo, reduce ex Hispania legatione, Torino, Stamperia Nazionale, 1817.

11 Several documents are kept at Archivio di Stato di Torino, Sezione Corte, Istruzione pubblica, Scuola per geometri e carte varie relative all'istruzione pubblica, testiment to Anselmi's role in the working group. In particular, besides the numerous letters and the material to be viewed that he received from Galeani Napione, is a Primo catalogo de' libri raccolti presso il sig. Anselmi, d'ordine avuto da S.E. il conte P.B. (Prospero 
with other collaborators, such as the Abbot Incisa, he had returned to running the College of the Provinces in 1814, the Abbot Leone, head of the school of Turin, the Count of Cardenas, head of a school of mutual teaching, and Anton Maria Vassalli Eandi, Professor of Physics at the University, a drafter of what is the most innovative and interesting draft reform of those years, but which of course, was not taken into consideration.

At the same time, Anselmi edited a draft reform of the Savoy school, entitled Ideata correzione al sistema di pubblica istruzione (1818), including the whole study cycle up to University, as was requested by Galeani Napione. The issues on which the working group belonging to Galeani Napione and Balbo were working on revolved around some very precise educational, cultural and political principles:

- the replacement of Latin with Italian as the language for primary literacy

- the distinction between different training routes for the rich and poor: whereas the second group would have stopped at Italian, taught in elementary schools, only the others would have gone on to Latin, in secondary schools.

- the use of the normal method practiced in Milan, as publicised at the time by the "Biblioteca italiana" [Italian Library]. They were also very suspicious of mutual education.

- the introduction of literacy of a sort of civic education from an early age, that would bring back the revolutionary experience, naturally changing the tone, focussing on the Catholic faith and on loyalty to the monarchy.

Just when the group was able to produce a comprehensive reform proposal, the revolutionary upheavals of 1821 erupted in Turin, as in other European cities, which directly involved the university students and they were determined, therefore, according to the best Savoy tradition, to close the University and the College of the Provinces. Balbo was definitely dismissed, while Galeani Napione found himself with his hands tied once again. The situation of the school system in the Savoy State returned in 1814. The few cooperative schools set up in Piedmont through private

Balbo) all'uopo di veder norme di pubblica istruzione, not dated, which indicates all the texts that Anselmi had received to view or that he had procured independently. 
initiatives and members of the royal family, including the future King Carlo Alberto, were also declared illegal and ordered to close.

\section{The First, Timid Educational Reforms}

The most significant and lasting results achieved by Balbo and Galeani Napione in their reform work were in the field of education, due really to Anselmi, who produced two highly original complete courses for primary schools: before the dismissal of Balbo, he printed the Scuola dell'infanzia divisa in tre fascicoli di lettura e preceduta da un ragionamento dell'autore intorno all'uso di questa e della seguente scuola della puerizia. Fascicolo primo per l'età dai 4 ai 5 anni, ${ }^{12}$ then, just when the actions of 1821 were kicking off, he completed the work with Scuola della puerizia fatta acconcia ai due sessi da Giuseppe Anselmi prete professore alla Regia Accademia Militare. ${ }^{13}$

Why were Anselmi's manuals so innovative, and have such good fortune, so much that they were reprinted in Piedmont more than half a century later?

Because with the traditional division of the Latin school into seven year groups, Anselmi replaced a course of tripartite studies, that distinguished between infancy, childhood and Latin letters, or adolescence. In this way, he used the stimuli coming both from the illuminated French literature, and especially Condillac and Rousseau, and from contemporary educational texts, such as those by Pestalozzi, Grégoire Girard,

12 G. Anselmi, Scuola dell'infanzia divisa in tre fascicoli di lettura e preceduta da un ragionamento dell'autore intorno all'uso di questa e della seguente scuola della puerizia. Fascicolo primo per l'età dai 4 ai 5 anni, Torino, Stamperia Reale, 1819, 3 voll. The work was dedicated to the Prince Carlo Alberto, a promoter of mutual teaching, who had chosen to "schiudere larga vena di gratuita istruzione come a militi scelti, così a giovanetti poverell" [open up large vein of free education as much for chosen militates, as very poor youngsters]. The text was preceded by Ragionamento di Proemio alla Scuola dell'infanzia e della Puerizia, fatta acconcia ai due sessi, di Giuseppe Anselmi, prof. di retorica alla Regia Accademia Militare di Torino, Torino, Pietro Giuseppe Pic, 1819.

13 G. Anselmi, Scuola della puerizia fatta acconcia ai due sessi da Giuseppe Anselmi prete professore alla Regia Accademia Militare, voll. 3, Torino, Pic, 1820-1821. 
Marc-Antoine Jullien, Anna Letitia Barbauld and the proponents of mutual learning.

Also, for the first time school texts were based on the cognitive development of students, on whose capacity the content was designed and the language defined. The first level defined by Anselmi "scuola dell'infanzia" [infants school] comprised two years and was aimed at literacy. The three years of the Latin school, from sixth to fourth, were, then, replaced by Anselmi with the "scuola della puerizia" [primary school], four years aimed at learning grammar (first universal and then Italian grammar), spelling, composition, history (religious, but also national and contemporary), geography, arithmetic and natural history. If the infant school was to teach "a conoscere ed accozzare i segni analitici ed espressivi della voce umana" [knowing and putting together the analytical and expressive signs of the human voice] and how to put together "segni e voce e pronuncia corrispondente a quei segni" [signs and voice and pronunciation corresponding to those signs $],{ }^{14}$ the primary school served to strengthen both religious feelings and the students' civic sense. The last two years of senior school were not just dedicated exclusively to the study of philosophy, but also Italian eloquence, mathematics and the physical sciences, subjects that not only would have guaranteed the effective link between the various levels of education, but would have equipped the students with the knowledge to deal with university successfully.

The fact that all the Anselmi's textbooks were inspired by the normal or simultaneous method, used way back in the Lombardy-Veneto schools, but still welcomed with mistrust in Piedmont, should not be ignored.

The last new element is Anselmi's attention to the way his books were used. He knew the ignorance of many of his colleagues and he knew that they would have to be helped in didactics. For this reason, before the fall of Balbo, he was called to hold a memorable method course to colleagues in local schools. Then after 1821, when there were less, not only possibilities of reform, but also experimenting with new teaching methods, he founded a journal, the "Educatore in famiglia" [Educator in the family], aimed both at school teachers and tutors, ${ }^{15}$ which was published for almost two years

14 G. Anselmi, Omaggio d'una orazione latina e di un'ideata correzione al sistema di pubblica istruzione, cit., p. 40.

15 On the "Educatore in famiglia" [Educator within the family] see the item by G. Chiosso in Id. (editor), La stampa pedagogica e scolastica in Italia (1820-1943), Brescia, La Scuola, 1997, p. 262. 
(from October 1823 to March 1825), and in which they devoted great attention, among other things, just to the conduct of lessons in class.

With the exception of the texts by Anselmi, no other novelty can be traced back to the few scholastic manuals (29, equal to $7.3 \%$ ) published during the short period in which Balbo was head of the Magistracy of the Reform. On the other hand, the books by Michele Sassetti were very much a product of the debate and experiments carried out in those years and were published in large part in $1822 .{ }^{16}$ These were conceived in line with the usual principles of charity school teaching methods, with which Sassetti was very familiar as a result of his position as principal of the charity school of Racconigi, founded by the Prince of Carignano, the future King Carlo Alberto. ${ }^{17}$ Although original and certainly innovative, the texts of this camaldolese were circulated only to a very limited extent, subject to the prohibition of the methods of Bell and Lancaster by the Kingdom of Sardinia in 1821.

\section{The Counter-reform of the Savoy School (1821-1827)}

1821 seemed to mark the end of any hope of reform for the Savoy state school system: Balbo was sent away leaving Galeani Napione with little

16 M. Sassetti, Tabelle di prime lettere, e di sillabario progressivo, Carmagnola, Pietro Barbiè, 1819; Id., Esercizi preparativi allo studio della gramatica e metodo facile di analisi gramaticale sulle tre parti primitive del discorso, e quindi sulle dieci parti secondarie generali in italiano e latino, Carmagnola, Pietro Barbiè, 1822; Id., Maniera pratica d'esercizio sulle sei significazioni de' nomi dette casi sulla coniugazione de verbi, sulle particelle, sulla distinzione d'una proposizione da un'altra, sulla sintassi d'accordo, e sull'analisi in ispecie ec. in italiano e latino, Carmagnola, Pietro Barbiè, 1822; Id., Esercizj d'analisi ossia di scomposizione delle proposizioni e de'periodi nelle loro parti e di costruzione nello stesso tempo, Carmagnola, Pietro Barbiè, 1822. Many other texts by Sassetti are conserved in manuscript form at the Biblioteca del Seminario in Turin, with numberings ranging from MS 17/1 to MS 17/37.

17 As regards Anselmi cf. G. Moriondo, Idee e progetti per una nuova scuola elementare nel Piemonte di fine Settecento: Giuseppe Anselmi, un maestro piemontese tra Rivoluzione e Restaurazione, p. 15-62, in "Bollettino della società per gli studi storici, archeologici ed artistici della provincia di Cuneo", no. 121, 1999, 2. As regards Sassetti cf. F. Monetti, Michele Sassetti (1762-1837) e i suoi tentativi di riforma in Piemonte, in "Benedictina", year 30, 1983, 2, pgs. 501-30. 
room for manoeuvre, also due to the fact that the office of Magistrate of the Reform was actually abolished and the regency of the school system entrusted to the ultra-reactionary Giambattista Viotti, who ran the Savoy school until 1825. Furthermore, the University and the College of the Provinces stayed closed for more than a year.

In reality, it was not a simple reactionary phase that opened up for the Piedmontese school after 1821 and that would last at least until the end of the 1820s. It was more a counter-reform. By entrusting the educational policy of the Kingdom to members of the Amicizia cattolica and the clergy, the Savoy government put them in a position where they could use the methods that the Church had employed for centuries in the fight against heresy: strengthening the presence of the religious teaching orders and restoring the models and cultural practices of opponents in order to re-convert them.

In fact, if until that time the restored Savoy monarchy was limited to a return to the situation prior to 1798 , following the uprisings of 1821 it realised that it was not possible to pretend that nothing had happened after the French occupation. Both the Republican governments, and the Napoleonic regime had introduced laws and cultural models in the field of education that had transformed the way education and schools were viewed and organised.

The Jesuits returned to be the great protagonists of the educational landscape in Piedmont and particularly in Turin. The Jesuits acquired the management of the Latin schools of San Francesco da Paola and Carmine, as well as the university colleges, mainly due to Viotti's support. ${ }^{18}$ In the meantime, individual Jesuits were called to fill strategic posts: in 1821, Antonio Grassi, Chancellor of the College of Turin, was appointed Confessor to the King and Queen, and Luigi (real name Prospero) Taparelli D'Azeglio, then Head of the College of Novara, had the task of developing a plan to reorder the school system, taking the place of Anselmi and the other Balbo and Galeani Napione advoisors.

Then came the light in July 1822, a year and a half after the fall of Balbo, the Regolamento per le scuole fuori dell'Università, which established

18 A. Monti, La Compagnia di Gesù nel territorio della provincia torinese. Memorie storiche compilate in occasione del primo centenario dalla restaurazione di essa Compagnia, Chieri, Ghirardi, 1914-1920, voll. 5, vol. 1, Prima della Provincia, pp. 188, 195 and 212. 
the rules that, with some small changes, were to determine how the Savoy school was run until $1848 .^{19}$

What did the Regulation order?

- The rigid distinction between elementary schools in Italian and the higher schools in Latin. In fact, the first level comprised local schools, which should have been open "per quanto sarà possibile in tutte le terre" [as far as possible in all lands] (Article 7). They considered two courses: one of reading, writing and catechism; the other of Italian, arithmetic and Christian doctrine. In fact, it was the old seventh class, separated as before into two courses and open, albeit separately, to males and females.

- The local schools followed the public schools or 'regie', distinguished on the basis of the nature of their funding, or in relation to the fact that they were paid for by the municipalities or the State. They were nothing more than a Latin course, comprising six classes, from the sixth to the first or rhetoric. The difference, compared with the past, lay in the fact that the municipalities could not have established a Latin school if they had not first found the money to keep the two courses at the local schools open. In this way, Taparelli D'Azeglio was trying to achieve the result that neither revolutionary governments, nor the Napoleonic Empire had managed to achieve: force the municipalities to renounce the Latin schools and open up basic courses in Italian for all.

- Expectations of the clergy from the Savoy school. In fact, the Jesuits were granted a far greater power than that which they had enjoyed in 1773, when there were suppressed by Pope Clement XIV. In 1824, the Brothers of the Christian Schools were allowed into the Kingdom, which before the Revolution had never been allowed to open schools in the Savoy State.

- The changes ordered by the law of 1822 were significant in respect of running and controlling the school but there were few new ideas regarding education: the only innovation, that however was not put into practice, was the adoption of certain practices borrowed in a generic way and even contradictory to normal schools and, to a lesser extent, mutual schools, such as the use of the best students as reciters. The

The Regolamento per le scuole fuori dell'Università is contained in Regie patenti colle quali Sua Maestà approva l'annesso regolamento per le scuole tanto comunali che pubbliche e regie, delli 23 luglio 1822. 
rest of school life was rigidly marked by Christian ritual, with masses, songs and prayers.

When you examine the measures laid down in the law written by Taparelli D'Azeglio in detail it seems clear that they made the innovations introduced by the Revolution and the Empire their own, by reversing their meaning. This why it is correct to speak of a counter-reform: Conservatives also began to consider literacy as an instrument of bias and protection of the monarchy: an educated populous would have better known how to defend themselves from revolutionary propaganda. Also the conservatives became inclined towards broadening the school's social base, convinced that it would serve as a new conversion, creating a moral society, which conjures up a new 1789. Paradoxically, if popular education was looked upon with suspicion and deliberately overlooked by the government and socio-cultural élites until the arrival of the Revolution in Piedmont, with the Restoration it rose to be an instrument for safeguarding institutional power, on a secular and religious level. Popular education was immediately perceived as vocational education: providing jobs for the poor was the only solution to the secular fear of the social classes being overthrown as a result of education. The objective, therefore, was no longer that of Kant to "make the man leave the minority state responsible for himself", and far less revolutionary by leading him to actively participate in the life of the state. Primary education accessible to all or almost all, the intentions of reformers such as Tapparelli D'Azeglio, and also as Balbo and Galeani Napione, aimed to contribute to the creation of good citizens and faithful subjects, without, however, any risk of undermining the foundations of society.

One of the main objectives proposed the law of 1822 was the removal of the French experience. Savoy Piedmont had experienced the shock of becoming French territory, while the rest of the peninsula became first the Cisalpine Republic, and then the Kingdom of Italy. Piedmont's identity had to be re-evaluated, in light of both being anti-French and also antiunification.

In this sense, even the fight for Latin in elementary school had to serve not so much to make access to primary literacy more democratic, in light of being anti-French, i.e. to erase the memory of the occupation. Moreover, since families continued to require the language of ancient Rome it was taught to their children from a very young age. In 1827 it 
was reintroduced by law as a subject in primary schools, not leaving these schools again until 1848.

Following Napoleon's example, Savoy also strengthened the power of the clergy, but with different intentions from those of the French emperor. If, for Napoleon, the introduction of the clergy in schools was to serve to better control the Church and religion, for Taparelli D'Azeglio, ecclesiastical teaching staff represented the best guarantee of a moral education. Thus it returned, not only prior to 1798 , but even prior to 1729 , when Victor Amadeus II redesigned the whole Savoy school system, removing it from the religious orders to entrust it to the State, for the first time in Europe.

\section{Education Serving Politics}

The reforms of 1822 also revived the scholastic book market as a result of two new types of textbooks: some texts were produced under the direct control of the Magistrate of the Reform, according to a measure from 1824; this was also probably desired by Taparelli D'Azeglio, who considered the use of teaching material consistent with the requirements of the new law and essential for his educational and political plans. Other textbooks were written spontaneously, or simply upon invitation from the Magistrate

In the first category were texts on teaching Italian, published for the first time between 1823 and 1824 by the Stamperia Reale and reprinted many times in subsequent decades:

- Antologia italiana approvata dall'eccellentissimo Magistrato della Riforma per le scuole superiori, Turin, at the Stamperia Reale, 1823

- Antologia italiana approvata dall'eccellentissimo magistrato della riforma per le scuole superiori

- Trattato della locuzione oratoria e dell'arte poetica approvato dall'eccellentissimo Magistrato della riforma ad uso delle scuole

- Grammatica italiana approvata dall'eccellentissimo Magistrato della Riforma ad uso delle scuole, Turin, at the Stamperia Reale, 1823

These were decidedly advanced texts compared with those in use in Piedmont schools until that time. Anthologies of Italian literature entered 
Piedmont's schools for the first time including modern authors, prior to that point excluded from studies.

Since Piedmont did not have a proper model for looking at the anthologies wanted by the Magistrate of the Reform they had as a model Antologia italiana ad uso dell'umanità maggiore nelle scuole del Regno d'Italia, published in Milan, by the Società tipografica de' classici italiani, in 1810 . Not by chance, the reference authors were the same; or rather the authors then become classics, such as the great Tuscan poets and humanists such as Bembo and Macchiavelli. But to these were added classic authors from Piedmont, in particular Vittorio Alfieri.

In line with the aims that had inspired the new law, the attention of the government focused first and foremost on the teaching of Italian. The said decision can certainly be explained by the fact that with the Regulations it intended to promote the extension of education to the masses in Italian, though this was not the only reason. One of the main objectives which the law of 1822 set itself was the removal of all French associations. Savoy Piedmont had experienced the trauma of being declared French territory. To cancel all traces of the same it was necessary to move away from French culture and language, notwithstanding the fact that they were an intrinsic part of the Kingdom of Sardinia, located as it was on both sides of the Alps. For this reason too the decision was taken to insist on Italian, whilst at the same time emphasising the peculiar character of Piedmont in both anti-French and anti-unification terms.

Moreover, lexicometric analysis too confirms the importance enjoyed during those years by the teaching of Italian literature and language. One of the words which occurs most frequently is in fact "language" - appearing no less than 67 times in the corpus of titles published in Piedmont between 1814 and 1839. Whether it was Italian or Latin, formal education at that time was for the most part aimed at learning a language, and in essence schools were still regarded, as in previous centuries, as language schools.

The second category includes textbooks not commissioned by the government or that were written and published on the initiative of individuals. Among these texts, those relating to three subjects are interesting for the purposes of our discussion on teaching: Italian grammar, history and geography.

As regards grammar, just as for the anthologies, authors from Piedmont looked to the neighbouring Lombardy where texts were in use which the government of Vienna had made teachers trained at the Normalschule 
in Vienna write, such as Giovanni Gherardini, Francesco Cherubini, Tommaso Grossi, Giovanni Berchet, Stefano Franscini, Ferdinando Bellisomi and the young Carlo Cattaneo. ${ }^{20}$ They brought books to Italy written on the basis of the precepts of the normal method "of second generation", or rather that were developed in Austria by Peitl and Milde, as a change to the teaching methods of Felbiger.

Those written for Austrian Lombardy were without doubt the most advanced textbooks of the time. The fact that they were imitated in Piedmont is very significant, because it certifies that for the first time the Kingdom of Sardinia opened itself up to a foreign method of teaching, with a strong air of having been created and designed for a different school system.

The contamination by Habsburg Lombardy, however, stopped with the acceptance of the normal method. The promotional content of textbooks continued to be marked by their perfect concordance with governmental guidelines. The compliance of the scholastic authors and educational texts towards the official pedagogy is proven by the explicit references to government guidelines contained in the grammars and texts for language teaching. An interesting case is the anonymous Secondo libro di letture per le scuole elementari (Turin, Stamperia Reale, 1840). In the part which outlines to the young reader the most common professions, inviting the pupil to "esaminare bene se stesso per conoscere a quale si senta più inclinato" [look deep inside yourself to find out to which you feel more inclined], specifying that "nessuna professione conviene meglio ad un figliuolo quanto quella del padre" [no profession suits a son better than that of father]. This was exactly the same reason why Taparelli D'Azeglio had reserved the study of Latin and therefore the possibility of accessing higher education degrees, only for children from wealthy families, reserving other vocational training for the others.

The presence of political contents was particularly evident in textbooks for other disciplines, including those of national history. They represented a major new approach in Piedmont, given that until the Revolution, the discipline was limited to antiquity. In the decades immediately after the Restoration three textbooks were published in the Kingdom of Sardinia:

20 With regard to relations between the authors of textbooks for the Schools of Lombady and the Milanese and Viennese authorities see the classic test by M. Berengo, Intellettuali e librai nella Milano della Restaurazione, Torino, Einaudi, 1980, pp. 192-198 and 346-355. 
- Luigi Cibrario, Notizie storiche sopra la storia dei Principi di Savoia date dall'avvocato Luigi Cibrario ad uso delle scuole del Regno di Sardegna, Turin, by Alliana e Paravia, 1825

- Gustavo Paroletti, Storia della R. Casa di Savoia dalla sua origine sino ai giorni nostri, in dimande e risposte, per Gustavo Paroletti, opera adorna di ritratti, Turin, at fratelli Reycends e Comp., 1834

- Francesco Lanteri, Storia della Monarchia di casa Savoia, approvata dall'eccellentissimo Magistrato della Riforma, per uso delle regie e pubbliche scuole, Turin, by the Stamperia Reale, 1835. The author says "onorato di questa difficile incumbenza" [honoured by this difficult task] which implied the fact that he had been instructed by the Magistrate

- Jean Frezet, Histoire de la Maison de Savoie par Jean Frezet prêtre de l'ex-congrégation-enseignante de S. Joseph de Lyon, professeur à l'Académie Royale Militaire, Turin, de l'imprimerie Alliana, 3 voll., $1826-1827$

- Davide Bertolotti, Compendio della istoria della Real Casa di Savoia per Davide Bertolotti, Torino, stamperia di Giuseppe Favale, 1830.

As appears evident from their titles, what distinguished the new history texts was the fact that the sovereigns of the House of Savoy and not their kingdom were placed at the centre of the narrative. As stated explicitly by Paroletti, "non vi è studio più necessario ai giovani che quello della storia dei loro Principi, e del paese che gli vide nascere, sia perché valgono queste nozioni a vieppiù far crescere quell'amore di patria di cui per natura sta il germe in cuore dell'uomo, sia perché l'esempio dato da coloro cui il destino volle affidare $i$ troni è il mezzo più efficace onde inspirare in ogni classe quell'amore alla cosa pubblica, che ben diretto, è il vero vincolo della civile società" [there is no more necessary study for young people than that of the history of their Princes, and of the country that witnessed their birth, because these concepts are all the more important for developing a love of country which by nature is planted the heart of men, and because the example given by those to whom fate wishes to entrust the thrones is the most effective means which inspires in each class that love for the public, which when well managed, is the real bond of civil society]. ${ }^{21}$

21 G. Paroletti, Storia della R. Casa di Savoia dalla sua origine sino ai giorni nostri, in dimande e risposte, per Gustavo Paroletti, opera adorna di ritratti, Torino, fratelli Reycends e Comp., 1834, p. XII. 
For this reason, the narration was centred on the figures of monarchs and on events, most of them wars that had marked their kingdom, with the objective of presenting the times as a new golden age, after a period of extreme decadence which coincided with the French occupation.

Transformations in the way the subject was understood were of no little significance. The same is shown, among other things, by the fact that, in the same years, Savoy teachers increasingly chose as their subject for theatre productions by their students not themes taken from the classics but episodes in the lives of monarchs. The students at the College of Carmine, directed by Jesuits, put on a production of the life of Eugenio of Savoy in 1832, Amedeo VI in 1834, Amedeo V in 1837 and Carlo Emanuele III in $1838 .{ }^{22}$ In addition, it is important to note that the first three Savoy kings had gained renown for their warlike virtues during the crusades, and Carlo Emanuele III too had spent a good part of his reign fighting in the various wars of succession that had thrown Europe into turmoil during the first decades of the eighteenth century.

A textbook of Italian and not just Savoy history did not appear until 1846, when Della storia d'Italia by Cesare Balbo (son of Prospero) began to be adopted in schools. It was not considered a book for teaching, but was widely used until the Italy's unification as a teaching text. ${ }^{23}$

If the task of history was to link Savoy's subjects to their King, geography, supplemented this work, using the study of the earth as an instrument to build and share national culture. This intention is clearly visible from the very first geography textbooks published in Piedmont after 1814:

22 Eugenio di Savoia conquistatore di Belgrado. Saggio che dei loro studii hanno dato i nobili convittori del Reale Collegio del Carmine diretto dai PP. della Compagnia in Turin l'anno 1832, Torino, Marietti, 1832; Amedeo VI conte di Savoia, liberatore di Giovanni paleologo, imperatore d'Oriente. Trionfo che rappresentano al pubblico i nobili convittori del Reale Collegio del Carmine, Torino, Marietti, 1834; Amedeo $V$ conte di Savoia detto il grande, liberatore dell'isola di Rodi contro Ottomano I. Trionfo che rappresentano i nobili convittori del Reale Collegio del Carmine, Torino, Marietti, 1837; Carlo Emanuele III, re di Sardegna. Accademia di lettere e d'arti che danno al pubblico sulla fine dell'anno 1838, i nobili convittori del Reale Collegio del Carmine, Torino, Marietti, 1838.

23 C. Balbo, Della storia d'Italia, Sommario, Torino, Pomba e C., 1846. 
- Jacques Antoine, Elementi di geografia moderna ad uso delle scuole, fifth edition with additions and corrections, Turin, by Giacinto Marietti tipografo-libraio, 1834

- Giacomo Bossi, Elementi di geografia politica ad uso degli allievi della R. Militare Accademia, del prete Giacomo Bossi, professore di lettere in essa Accademia, Turin, Tipografia Cassone, Marzorati, Vercellotti, 1834

- Marquis Carlo Tancredi Falletti of Barolo, Lezioni sopra la geografia patria ad uso della gioventù piemontese, Turin, by Giacinto Marietti tipografo-libraio, 1836.

- Claude Buffier, Geografia universale del p. Buffier, coll'aggiunta in principio del Trattato della Sfera del p. Jacquier, Nuova edizione con aggiunte ornata di XXIV carte geografiche, Turin, by the printer Luigi Soffietti, 1821.

While discussing borders, capitals, the economy, the customs and costumes of individual countries, they expressed opinions on their history and on their forms of government, naturally preferring monarchies. Furthermore, they also paused to consider "carattere nazionale" [national character], judging it merely by political order and the country's religion. This was also a way to bring out the singularity and superiority of the Kingdom of Sardinia and its inhabitants, often defined as "industriosi, amanti dei forestieri, fedeli al loro Sovrano, cortesi e zelanti della Religion Cattolica" [industrious, lovers of foreigners, faithful to their sovereign, courteous and zealous of the Catholic religion]. ${ }^{24}$

\section{The Birth of Modern Textbooks}

Some other textbooks transformations in Piedmont from the Restoration must be mentioned in addition to the above: in the first place, it should be emphasised that not only were used books removed from the market during the French occupation, but texts written in French decreased drastically,

24 Claude Buffier, Geografia universale del p. Buffier, coll'aggiunta in principio del Trattato della Sfera del $p$. Jacquier, Nuova edizione con aggiunte ornata di XXIV carte geografiche, Torino, Luigi Soffietti, 1821, p. 96. 
until they disappeared. Until 1798, lots of textbooks in French were used by teachers in Piedmont, as the Savoy State had always been bilingual. After 1814 , French was always more clearly presented as a second language, on a par with other foreign languages.

Furthermore, the use of scientific subjects as the basis for primary literacy was abandoned; promoted as an idea towards the end of the 1700s and actively on the school curricula of the Revolution. The first defeat occurred in 1811, when the science subjects were drastically reduced on the curriculum of Napoleonic schools, but its eventual defeat was approved by the Restoration, when the sciences returned to be consciously overlooked both in primary and secondary schools. It was an almost final defeat that ultimately assigned grammar and the humanities the task of bringing children and young people into contact with culture.

If in the public arena, i.e. policy, the Savoy state did not accept positions other than official positions, in fields more linked to the private sector, such as religion however, students from Piedmont and their families had a little more freedom of choice. This seems to be shown by the wide variety of first reading books and spelling books produced in the Kingdom of Sardinia after the Restoration.

Typographers and printers tried to meet the demand created by the market of teachers and tutors who wanted to be able to take advantage of elementary books with an approach that was not overtly religious. In that respect the editorial strategy of the booksellers Reycends of Turin appears as an example which in 1819, printed two first reading books the Abecedario sacro sopra l'antico e nuovo testamento, per insegnare ai fanciulli a leggere ed istruirgli ad un tempo nella Storia Sacra and the Abecedario mitologico, ossieno lezioni tratte dalla favola. ${ }^{25}$

The first parts were identical, they introduced letters and syllables and offered instructions on how to hold the nib and approach the difficult practice of writing. The dimensions, subtitles, iconography and layout of the two books were the same for the first 68 pages, a clear indication that a unique matrix had been used. ${ }^{26}$ The two books by Reycends only varied

25 L. Braida, Il commercio delle idee, Editoria e circolazione del libro nella Torino del Settecento, Firenze, Olschki, 1995.

26 The two texts were: Abecedario sacro sopra l'antico e nuovo testamento, per insegnare ai fanciulli a leggere ed istruirgli ad un tempo nella Storia Sacra, Operetta adorna di varj rami, contenente gli articoli seguenti: $1^{\circ}$ Alfabeti e Tavole per la compitazione; $2^{\circ}$ Abbaco e tavola Pittagorica spiegata; Della Pronunzia e dell'ortografia; 
in the final pages: while the Abecedario sacro showed short stories drawn from the Bible, with prints which provided a sort of snapshot of the episode, the Abecedario mitologico closed instead with fairy tales that had formerly comprised the religion of the ancient Egyptians, the Greeks and the Romans, ${ }^{27}$ or with events from the life of the most well-known classical Gods, they were also accompanied by small and basic illustrations.

There were differences that did not concern the ways in which reading and writing was introduced. It was not that the didactic aspect interested authors and buyers of the two study books, but rather the content of those first reading books, intended to capture the imagination of young users and to lay the foundations for their cultural development. In later years the supply of first reading books and first letters books would be further expanded, as shown by, among others, the subsequent catalogues from Turin's booksellers, which featured the Abecedario di storia naturale (1835), the Nuovo alfabeto e sillabario (1835), the Nuovo abbecedario di scienze ad uso dei fanciulli che incominciano a leggere (1836) and the Alfabeto flora per fanciulli (s. d.).

If these study books were able to circulate it was not so much because of the religious field of education, but mostly as a result of their use: first reading books and spelling books, in fact, were the first books that the students picked up and primary education often took place, especially for the wealthy, not at school, but within the family or with tutors. There the State was unable to reach them and didactics still could not make them interested in politics.

The most important innovation, in effact, was the introduction in Piedmont of the books and the didactics develped in Habsburg Lombardy following the normal method. The fact that those manuals were imitated in Piedmont is very significant, since it proves that for the first time the Kingdom of Sardinia was opening up to a foreign didactic method, one that was very much the product of its birth and conception within a different scholastic system. In Turin Grammatica della lingua italiana by Bellisomi was

$4^{\circ}$ Metodo di bella scrittura; $5^{\circ}$ Regole di buona condotta ed urbanità; $6^{\circ}$ Tratti di Storia dell'antico e nuovo Testamento, Turin, Reycends e Compagnia, 1819; Abbecedario mitologico, ossieno lezioni tratte dalla favola, Operetta adorna di rami e di somma utilità pei fanciulli, contenente gli articoli seguenti: $1^{\circ}$ Alfabeti e Tavole per la compitazione; $2^{\circ}$ Abbaco e tavola Pittagorica spiegata; Della Pronunzia e dell'ortografia; $4^{\circ}$ Metodo di bella scrittura; $5^{\circ}$ Regole di buona condotta ed urbanità; $6^{\circ}$ Lezioni di lettura tratte dalla Favola, Torino, Reycends e Compagnia, 1819. 
reprinted (published by Reviglio in 1833 and 1837), in addition to the now classic Grammatica ragionata della lingua italiana by Francesco Soave, which achieved its fourth edition in 1838 .

Other texts were written by Piedmont teachers. The first and most prolific of which was without doubt Michele Ponza. A priest and teacher of Latin in the City of Turin's schools, Ponza combined the activity of both expert and disseminator of Italian grammar. ${ }^{28}$ Indeed, in addition to printing some best sellers for schools, he founded and for many years directed the "Annotator of language errors", with Piedmont and Lombard teachers, men of culture and politicians contributing to the same, including Carlo Boncompagni. ${ }^{29}$ The journal focused above all on literature, taking as its model the Milanese, "Italian Library", though from its very beginnings it dedicated considerable space to the treatment of scholastic and educational matters. Many of the editors, starting with Ponza, a teacher in Turin's municipal schools, were in the classrooms every day and therefore wrote about education from direct personal experience.

For many reasons the books by Ponza constitute the culmination of a series of transformations that books for schools and education underwent in the first decades of the 19th century. They can therefore also serve as an illustration of the said evolution. The first reason for their originality lies in the fact that the texts written by Ponza in the 1830s were the first to be conceived for a very specific public i.e. for teachers and pupils of individual classes. The second reason is the introduction on the Piedmont scholastic book market of texts with arrangement and contents that are very different from those of the past.

Lexicographic analysis helps to illustrate the peculiarities of the manuals by this Savoy man of letters. Indeed an element that distinguished educational and didactic books from the very first decades of the $19^{\text {th }}$ century was the reference, as indicated in their titles, to their educational purpose. Often too a very specific category of readers was targeted. Indeed, no less than 153 texts had a title with the words "for the use of" ("ad usum" in

28 As regards the didactic and pedagogic activity of Michele Ponza (1772-1846), who was a leading teacher, journalist and man of letters in Restoration Piedmont, see C. Marazzini, Il "Donato piemontese-italiano", didattica popolare dell'italiano e discussioni linguistiche nel primo Ottocento, in "Studi Piemontesi", March 1983, vol. XII, pgs. 3-16.

29 The journal directed by Ponza enjoyed a long life. Publications continued from 1829 to 1845 . During the course of its life the journal had various titles, the most significant of which was "L'Annotatore piemontese". 
Latin or "à l'usage" in French texts), while another 13 works had the word "useful" in their title or were written for "use" or "utility".

In reality, however, the target audience was precisely defined much more rarely than a modern reader would expect, accustomed as we are to a scholastic system in which the progression of classes and school levels is rigorously organised. Only in 75 cases was the term "use" associated with the word "school" (e.g. for use in "royal schools", "primary schools", "schools of Italy" etc.), while in all the other cases (78) the titles referred to a much more generic "studious youth", "Piedmont youth", "tender youth" or still more vague "boys and girls" and "youngsters".

In effect, the frontispieces of Piedmont scholastic books often imply non scholastic readers and utility contexts e.g. "youth" (37), "youngster/s" (10), "young" (8), "boys and girls" (35), "infancy" (4), "childhood" (5), "beginners" (3), "father" (8), "home" (4).

Nevertheless, the reference to the scholastic context was frequent in the titles of books: "school/s" is the term present the greatest number of times in the corpus after the word "use", given that it appears 83 times. Among the Latin titles, "schola" is even more common (19 uses out of 46 titles). Indeed, in percentage terms, the reference to school in Latin text books was much greater than in Italian books (41\% against $24.8 \%$ ). Latin continued, in other words, to represent the language of schools, while in Italian scholastic use was anything but automatic. Following the Restoration of Savoy, French too was increasingly relegated to formal education contexts. This is also shown by the titles of the few books (barely 10 for the entire period under consideration) written in French, 30\% of which included the explicit reference to "école".

In the titles of the Piedmont books other words occur with a specifically scholastic use, such as "teacher/s" (14), "professor" (6), "student/s" (3), "scholar/s" (14), "pupil/s" (8), "class/es" (6), "school boys" (2). Although the term "teaching" (3) was always used relative to works explicitly focusing on schools, other words which today are used in almost exclusively didactic contexts like "education" (12) and "lessons" (18) were used in an undifferentiated manner for all types of utilities. On the other hand, "education" (3) was always associated with a scholastic context.

For the entire period under examination there are only rare references to specific schools and classes. An exception is constituted by the Royal Military Academy, for whose students some 16 books were written between 1814 and 1839, in compliance with the best Savoy tradition, which 
as of the first half of the 18th century had allocated huge financial and cultural resources to the education of officers in the army (e.g. the prestigious School of Artillery and Fortifications).

The true leap forward in quality was, however, represented by the manuals by Michele Ponza. These were the first to be specifically conceived for teachers and pupils of specific classes. The structure of the books by the Savoy man of letters reflected the precise idea that Ponza had of the progression of learning and teaching to which students were called upon to respond.

Moreover, it was this individual method, which required teachers to attend to one pupil at a time, within classes that did not take into account the level of student learning or age, that made books with heterogeneous contents so useful for teachers. With the progressive introduction of the normal method in Savoy classes it also became necessary for the Kingdom of Sardinia to have a sequential series of books that gradually accompanied youngsters in their studies, adapting contents and methods to their level of ability. Ponza carried out, as one man, what had been prescribed in the whole of Lombardy-Veneto by the Commission for Studies i.e. he produced manuals that were calibrated in line with the level of progress of the students in question. ${ }^{30}$

This is also why he created the Latin course for the first elementary classes, from the sixth to the third year, in addition to grammar and the Piedmontese-Italian dictionary. ${ }^{31}$ For those who, like Ponza, were involved with classes on a daily basis, it was absolutely clear that for many pupils not only Latin, but Italian too was effectively a foreign language, accustomed as they were to speaking in their local dialect. For this reason he wrote grammar and vocabulary books that acted as a kind of bridge, helping students to move on with their study of the national language: the Donato piemontese-italiano, ossia Manuale della lingua italiana ad uso degli scolari piemontesi (Torino, Baglione, Melanotte and Pomba,

30 As regards the evolution of didactics and the consequent transformation of scholastic books in Italy in the early 19th century cf. P. Bianchini, Tra utopia e riforma della scuola: la metodica e il libro per l'istruzione elementare nell'Italia della Restaurazione, in G. Chiosso (editor), TESEO, Repertorio degli editori per la scuola nell'Italia dell'Ottocento, Milano, Editrice Bibliografica, 2003, pp. XXIX-XLVIII:

31 M. Ponza, Manuale del maestro e dello scolaro di terza, di quarta, di quinta, di sesta, ossia metodica per insegnare e apprendere i principj della lingua latina, Torino, Favale, 1838, 4 vol. The first edition was published in individual volumes, and was printed in Turin by Favale himself as of 1836. 
1838), the Dizionario piemontese-italiano, approvato dalla $R$. Direzione delle scuole, Torino, Ghiringhello, 1827, second edition), the Dizionarietto piemontese-italiano, contenente le voci puramente piemontesi e di uso famigliare e domestico (Torino, Royal Printing House, 1831) and, later, the l'Antologia piemontese per esercizio di traduzione dal piemontese all'italiano parlare (Torino, Mussano, 1844).

In addition, he devised his texts relative to the level of preparation of the teachers. Clearly distinguishing those parts for students from those for teachers, Ponza's manuals sought to help teachers in their organisation of lessons, with practical advice and exercises and questions to be used in the classroom. In agreement with his more perceptive colleagues, the Turin philologist was convinced that the reasons for the failure of the schools was not due for the most part to the pupils but the teachers, and even more the didactic methods employed. Updating didactics meant, therefore, renewing the schools, even in the absence of any overall reforms of the education system. ${ }^{32}$

Finally, Ponza also contributed by introducing a new way of defining school books into everyday language. Until the 1830 s the most frequent way of defining a school text was "compendium", used 34 times in the corpus under examination. ${ }^{33}$ The frequent use of this word is explained by the fact that it traditionally indicated a very specific type of book: a compendium represented an alternative to the catechism, given that it was not organised in a question and answer format but was expositional in character. $^{34}$

Between 1814 and 1839 the term "catechism" was progressively abandoned, appearing only six times in the titles of books published in Piedmont. At the time, thanks to the influx of Austrian pedagogy and, more specifically, that of Milde, the "natural method" was replacing the

32 Ponza also wrote some very innovative texts on methods in Piedmont in the early 19th century: Lettera d'un maestro di Scuola Comunale ad un suo collega, intorno all'insegnamento della lingua italiana nelle Scuole Comunali, (Torino, Bianco, 1823 ) and Dei primi maestri dei giovanetti, ossia esercizj teorico-pratici di Pedagogia (Torino, Chiara, 1828).

33 Other forms included: "compendium" (2), "abridged" (2), "summary" (2), “condensed" (1), "concisely" (1).

34 The exclusive use of the two terms is explicit in Asigliano di Verrua, Lezioni metodiche di storia sacra ridotte in compendio ed in catechismo. Precedute da un discorso preliminare per indicarne l'utilità. Dedicate a monsignore Francesco Alciati vescovo di Casale, e conte dal teologo Asigliano di Verrua, Torino, Davico e Picco, 1824, 4 vol. 
"exposition-Socratic" method as a better "form of education". In reality, for a long time the two "forms" coexisted, in that the most innovative authors too were aware of the fact that a didactic transformation of such significance required time for it to be assimilated by colleagues, and even more time for students. It was no coincidence that Ponza, after publishing a major Italian grammar in four volumes in 1831, organised in question and answer format, produced a Compendium in narrative format in 1833, with both works enjoying considerable success for many years. ${ }^{35}$

In the meantime the term "manual" had started to be more widely used in the 18th century, switching from a religious and devotional to a didascalic and educational context, although it still remained extraneous to schools. In addition to the classic "religious" and "sacred" manuals, texts began to be published with titles like the "boiler maker's", "stove maker's" or "gun maker's" manual, or the "farming" or "miner's" manual, through to the "printer's manual" by Giambattista Bodoni.

As regards Piedmont, Michele Ponza is without doubt the author who more than any other contributed with his texts to introducing the term into the world of schools, using it in no less than eight scholastic texts between 1836 and 1839 as the title of manuals in his Latin course for classes from the sixth to the third year. ${ }^{36}$ Ponza adopted the term for the first time in 1836, almost at the same time as De Bartolomeis who in 1834 published both a Course and a Manual of German grammar, both aimed at cadets in the Military Academy and therefore, in a certain sense, still employment oriented. ${ }^{37}$ Previously Ponza called his education books compendiums or course books, as in the case of the first published text, entitled Il nuovo Gallerone, in honour of one of the most successful Savoy didactics innovators. $^{38}$

35 The two books by Ponza: Della gramatica della lingua italiana libri IV, cit. and Compendio della grammatichetta della lingua italiana, Torino, Fodratti, 1833; the second edition, by Cassone, Marzorati and Vercellotti, in 1835, was explicitly dedicated to public and private teachers of the basics of the Italian language.

36 Overall, between 1834 and 1839, the Savoy printers published no less than 12 "manuals".

37 The texts by De Bartolomeis, both published by the Stamperia Reale in 1834, were Corso teorico-pratico di grammatica tedesca ad uso degli allievi della Regia Militare Accademia and Manuale di gramatica tedesca ad uso degli allievi della Regia Militare Accademia.

38 In the light of the success enjoyed by the Roman grammarian, Aelius Donatus, whose name, over the course of the centuries, had become synonymous with elementary 
What distinguished Ponza's manuals from the grammar books that he had published earlier was above all the fact that they were aimed at lecturers and students, at the same time focusing, as clearly stated in their very subtitles, on "teaching and learning in an ordered and graded manner". From the sixth to the third year, the difficulty and complexity of ideas was carefully graduated, while teachers were instructed step by step in their use of the texts and their evaluation of pupils.

The success of Ponza's books indicates that the entry of the manual in the world of schools - not just in Piedmont but across Italy - was one of the fruits of the didactic innovations introduced by the Austrian pedagogy of the early $19^{\text {th }}$ century. The entire scholastic vocabulary underwent a radical evolution. More technical words gradually became familiar, like "method" (used in 19 titles), "course" (10), "elements" (14), "tract" (22), "small tract" (11), "pathway" (4) and "guide" (3). Other words, which had already for some time been part of education language, acquired an increasingly more scholastic implication and were frequently used on the covers of books e.g. "lessons" (15), "precepts" (11), "rules" (6), "principles" (5), "education" (3) and "exercises" (2).

In Piedmont too, the professionalization of teachers seems to coincide with a greater definition of disciplines and the birth of techniques

books for teaching first Latin and then Italian, i.e. the "Donato", other fortunate authors had the same success in Piedmont in the early $19^{\text {th }}$ century: Louis Goudar with French and Giuseppe Gallerone with Italian and Latin. The French grammar book in honour of Goudar was imported from nearby Lombardy (Il Goudar moderno, grammatica francese teorico-pratica, migliorata ed arricchita di regole, di esercizii di una fraseologia e delle voci omonime di Luigi Detoma, Torino, Società Tipografico Libraria, 1832. The Milan original was printed with the same title in 1825 by the bookseller Giovanni Meiners), whereas the course in honour of Gallerone was a typical Savoy product and represented the approach which Ponza, in his first production as an author of books for schools, wanted to revitalise a method, rather than just a text, that had marked an important phase in the history of didactics in the Kingdom of Sardinia. At the same time, Ponza indicated to his colleagues, relative to whom the reference was undoubtedly explicit, a noble predecessor of his own way of understanding grammar and the way it should be taught. M. Ponza, Il Nuovo Gallerone, ossia nuovo e dupplice corso di trecento temi latini e di altrettanti italiani tratti fedelmente dalle opere de' più accreditati scrittori latini e italiani; adattati alle due prime classi di latinità inferiore; corredati di note grammaticali a piè di pagina, di due dizionarietti italiano-latini e viceversa indicanti il vario reggimento de' nomi e de'verbi, ecc. e in fine di alcune nuove regole di traduzione dall'una nell'altra lingua, Torino, Favale, s.d., but later than 1826 . 
and knowledge that is typical of the school environment, comprising not only increasingly more precisely defined contents but also specialist vocabulary. ${ }^{39}$ And as of this period, to master both aspects, teachers had to undergo an appropriate period of training.

\section{Bibliography}

M. Berengo, Intellettuali e librai nella Milano della Restaurazione, Turin, Einaudi, 1980.

P. Bianchini, Libri per la scuola e pratiche d'insegnamento in Piemonte alla fine del Settecento, in G. Chiosso (a cura di), Il libro per la scuola in Italia tra Sette e Ottocento, La Scuola, Brescia, 2000, pp. 11-60.

P. Bianchini, Educare all'obbedienza. Pedagogia e politica in Piemonte tra Antico regime e Restaurazione, SEI, Torino, 2008.

P. Bianchini, (a cura di), Le origini delle materie. Discipline, programmi e manuali scolastici in Italia, Sei, Torino, 2010.

L. Braida, Il commercio delle idee, Editoria e circolazione del libro nella Torino del Settecento, Florence, Olschki, 1995.

G. Chiosso (provided by), La stampa pedagogica e scolastica in Italia (1820-1943), Brescia, La Scuola, 1997.

G. Chiosso, Carità educatrice e istruzione in Piemonte. Aristocratici, filantropi e preti di fronte all'educazione del popolo nel primo ' 800 , Sei, Torino, 2007.

E. De Fort, Problemi dell'istruzione primaria in Piemonte dalla Restaurazione alla formazione dello Stato unitario, in "Bollettino Storico Bibliografico Subalpino", LXXV, 1975, pp. 685-703.

G. Griseri, L'istruzione primaria in Piemonte (1831-1856), Torino, Deputazione subalpina di storia patria, 1973.

L. Guerci, "Mente, cuore, coraggio, virtù repubblicane”. Educare il popolo nell'Italia in Rivoluzione (1796-1799), Torino, Tirrenia Stampatori, 1992.

39 Relative to the same see A. Viñao Frago, La historia de las disciplinas escolares, in "Historia de la Educación", 25, 2006, pgs. 243-269. 
C. Marazzini, Piemonte e Italia. Storia di un confronto linguistico, Torino, Centro Studi Piemontesi, 1984.

A. Monti, La Compagnia di Gesù nel territorio della provincia torinese. Memorie storiche compilate in occasione del primo centenario dalla restaurazione di essa Compagnia, Chieri, Ghirardi, 1914-1920, voll. 5.

M. Roggero, Il sapere e la virtù. Stato, Università e professioni nel Piemonte tra Settecento e Ottocento, Torino, Deputazione Subalpina di Storia Patria, 1987.

M. Roggero, Insegnar lettere, Ricerche di storia dell'istruzione in età moderna, Edizioni dell'Orso, Alessandria, 1992.

M. Roggero, Scuola e riforme nello stato sabaudo, L'istruzione secondaria dalla Ratio Studiorum alle costituzioni del 1772, Torino, Deputazione Subalpina di Storia Patria, 1982. 



\title{
Teaching Geography after the Unification of Italy. A GIS Application for the History of Education*
}

\begin{abstract}
The essay investigates the history of textbooks from a quantitative perspective, by experimenting a new research instruments for the history of education. The data from geography textbooks used in Italian schools from 1874 to 1875 will be examinated with a Geographic Information System (GIS), which allows a very refined research of records with historical and geographical information. It will be showed the concrete potentials offered by the computer applications to human subjects such as history. Moreover, by using geography as an object and research instrument at the same time, through GIS, the essay will analyse the strategies of adapting manuals by the instructors, showing how a textbook success was based upon its ability of addressing the teachers' patriotic feelings.
\end{abstract}

\section{Introduction - A Geo-referenced Approach for the Study of Textbooks}

Textbooks represent a source of exceptional interest for the historian of education and offer useful information on the history of didactics, the

* I would like to thank Doctor Gabriele Andreozzi who introduced me to the world of the georeferencing of facts, providing me great help and many stimulating discussions with much patience; Carmen Betti and Angelo Gaudio for their advice and stimulating discussions. The essay was presented, in a first version, at the conference The school and the Italian culture through the textbooks and reading books. New methods of analysis and interpretation, Turin, 10-11 april 2008 (and therefore published by P. Bianchini (ed.), Le origini delle materie. Discipline, programmi e manuali scolastici in Italia, Torino, SEI, 2010. 
teaching of various disciplines, the relationships between adults and children and so forth. Surely the analysis presents itself as more complex than it may appear at first glance. The book in fact provides us with more data on who wrote it and on the collective idea on school, than on its actual use in the daily scholastic routine. These considerations (in addition to many others on the difficulty of the source) bring to a particular interpretive attention.

Furthermore, there is a main basic problem which consists in being able to understand which books were actually used in school. We have interesting data at a local level that can be found in the historiographic production of the pre-unification period or the one concentrated, after unification, on specific and defined territories. It is not easy, however, to have a definite big picture that, as a matter of fact not even the national ruling class had in the years immediately following the birth of the Kingdom of Italy. The attempts to find information, above all statistical, on the adopted books are a testimony of the attempt. Among these attempts, it is very important to mention a survey promoted by Ruggiero Bonghi ${ }^{1}$, public instruction minister during Minghetti's second term as Prime Minister. Even though previous surveys exist, Bonghi's one presents particular qualities that allow to analyze it through a quantitative approach. For the first time, in fact, the request for information (to all educational inspectors) is very clear and prevents confusion, so frequent at the time, between the adoptable books and those actually adopted in the curricula. In the ministerial report, in fact, the objectives of the request are indicated as such: "to make known (...) with a detailed connection, which are the textbooks most adopted in elementary schools, by indicating in particular the qualities of those books that turned out to be successful, and the defects of those that, instead should be banned from school" 2 .

It is necessary to start by mentioning that this survey, from a quantitative point of view, if compared to the resident population, regards about half of Italy (as from the most recent census, that of 1871: naturally it is

1 The survey is conserved at the State Central Archives, Roma, Consiglio Superiore (1849-1903), Atti versati posteriormente, envelope 4: it contains two pamphlets, one dedicated to secondary schools, the other with the answers, dated 1874 and 1875 , by the educational inspectors to minister Bonghi's request relative to elementary schools.

2 Circular n. 405, November 1, 1874, "Bollettino Ufficiale del Ministero della Pubblica Istruzione”, December 15, 1874, p. 36. 
possible to adopt other evaluating methods, too). Moreover, the inspectors' responses cover adequately the north-south/islands axis: we can therefore reasonably consider it as an actually representative and sufficiently articulated sample on the territory ${ }^{3}$.

In sum, it is a reliable and an extremely interesting source that provides some firsthand data on the textbooks used, and, for the major focus in this essay, on the geography books. It is a source that allows observing aspects of difficult approach (if not impossible, in some cases), such as the circulation of books in various territories, the relationship between books at a local level and those at a national one. The clarity of the minister's request, the clarity of the majority of the responses and in some cases also the detailed information and topics provided, allow us to have a general picture but also some interesting and detailed data.

The difficulty of having information on this topic, in terms of production and circulation, was therefore deeply felt. It was actually a real demand as we can infer, for example, from a reading of the first biographical Italian yearbook, published by the public education ministry in $1863^{4}$. If we compare the bibliographical references with the facts at our disposal (starting from those great studies on educational publishing and those obtained from Bonghi's survey ${ }^{5}$ ), we discover that the yearbook in reality did not represent but a specific selection of textbooks production (or destined to educational use), in particular for primary school.

To examine the survey's numerous documents, that is the inspectors' responses (presented, at times, with real explanatory appendixes ${ }^{6}$ ),

3 On these general basic themes, refer to my presentation on the source in the article: G. Bandini, Contributo alla storia quantitative del libro scolastico: notizie su una ricerca in corso, "Bollettino CIRSE", 2005, 42, pp. 3-8.

4 Minister of public instruction, Annuario bibliografico italiano, A. I (1863), Torino, Tip. Cerutti and Derossi, 1864.

5 G. Chiosso (ed.), TESEO. Tipografi e editori scolastico-educativi dell'Ottocento, Milano, Editrice Bibliografica, 2003; G. Chiosso (ed.), TESEO '900. Editori scolastico-educativi del primo Novecento, Milano, Editrice Bibliografica, 2008; Edisco, database on the textbooks, on line resource available at www.reseducationis.it (see G. Bandini, P. Bianchini, Innovative Experiences in Digital History of Education: the Case of Reseducationis.it, in V. Cappellini, J. Hemsley (eds.), Electronic Imaging and Visual Arts. EVA 2008 Florence Proceedings. Firenze, palazzo dei Congressi, April 16-18, 2008, Bologna, Pitagora, 2008, pp. 174-179.

6 See for example the Relazione of Giuseppe La Guardia, inspector for the areas of Cosenza and Paola (ACS, CSPI, b. 4, Scigliano, April 14, 1875, prot. n. 215). 
an analysis of the single documents is not sufficient. We run the risk of losing, in fact, the general picture in which the qualitative analysis also assumes a new and more interesting meaning. This is why I propose a geo-referenced approach, using the great heuristics possibilities offered by the GIS applications (Geographic Information System). It is a field of study (and of methodological research) that in the historical area is still at the experimental state, opened to debate but with interesting perspectives of research ${ }^{7}$.

Despite its being at an initial stage, the open discussion has in fact added a new methodology to the historian's instruments. The GIS deals with complex instruments that require specific training and that, like all quantitative methodologies, tend to specialize whoever uses them, to gather scholars and associations around a specific vocabulary and a series of practices greatly distant from the usual qualitative practices of historical research.

Furthermore, in the past few years we have assisted to a growing interest by single scholars (and in particular those who have cultivated quantitative approaches for a long time) and also by some institutions. The construction of national geo-referenced systems is in fact an important element in developing historical studies in need of a new typology of historical archive. This type of approach (still limited to some states and to pilot experiences) is joined by a progressive diversification of basic themes, always along the idea of connecting history and geography: an old link that has seen in the French historiography the frontrunner for historical studies aware of the importance of the environment study. History and geography, in this sense, are both necessarily involved, almost faces of the same medal, and the GIS

7 See, for the state of methodological discussions, Ian N. Gregory, Karen K. Kemp, Ruth Mostern, Geographical Information and Historical Research: Current Progress and Future Directions, "History and Computing", 2001, 1 (publ. 2003); J. B. Owens, Toward a Geographically-Integrated, Connected World History: Employing Geographic Information System (GIS), "History Compass", 2007, 5/6. An interesting study case in L. Siebert, Using GIS to Document, Visualize, and Interpret Tokyo's Spatial History, "Social Science History", 2000, 3. In Italy, see R. Paolini, Geografia storica, Gis e internet, "Contemporanea", 2002, 3; K. Lelo, F. Palazzo, L'alluvione di Roma nel 1870: una ricostruzione con tecniche G.I.S., "MEFRIM. Mélanges de l'École française de Rome - Italie ed mediterranée”, 2006, 1. 
methodologies do highlight (another time, we should say) the need to connect the two areas of study ${ }^{8}$.

We can state, in fact, that historians always have a geographic vision and use spatial information in their work. However, we must notice the difficulty in fully integrating these facts in the historical argument: aspect that ends up in their constant underuse. The systems of georeferencing (that in reality already have a long technological tradition) guarantee the historians with a full usage of geographical data which, however, need to be adjusted for effective benefits. Historians need to adjust these methods/ data for their own specific field of research (very different from the original), reflecting on their multiple implications and verifying, in various thematic areas, their actual effect.

From this point of view, we can underline how important the methodologies of geo-referencing appear today for scholars who work in the perspective of a World History, either for their distinctive capacities of synthesis or their heuristic approaches that are their powerful features?.

As far as the single themes/topics covered through GIS methods are concerned, at the beginning they dealt mainly on aspects of urban histo$\mathrm{ry}^{10}$ and of the history of architecture, but in reality they can be extremely useful in many other areas, including the educational research. Some applications are focused on the didactic and popular approach of history, often with results of great interest ${ }^{11}$. As an example, it is worth mentioning

8 See the classic volume of L. Gambi, Una geografia per la storia, Torino, Einaudi, 1973; Karen K. Kemp, What can GIS offer history?, "International Journal of Humanities \& Arts Computing”, 3 (1-2) 2009. In the same issue see in addition: James W., Wilson, GIS and historical scholarship: A question of scale; O. Boonstra, Barriers between historical GIS and historical scholarship.

9 J. B. Owens, Toward a Geographically-Integrated, Connected World History: Employing Geographic Information System (GIS), "History Compass", 2007, 5/6.

10 Pinol J.-L., Les atouts des systems d'information géographique - (SIG) pour "faire de l'histoire" (urbaine), "Histoire Urbaine", 26, 2009.

11 Gis for History, University of Illinois at Chicago: "The goal of the project is to create and share history curriculum materials and lesson plans using historical census data and primary source on-line documents within a web-based GIS" (www. gisforhistory.org). See comment of the website, J. Radinsky, B. Loh, J. Lukasik, GIS tools for historical inquiry: Issues for classroom-centered design, "Journal of the Association of History and Computing", 11 (2), 2008. In the same issue see in addition: J. Brown J., Using GIS to Drive Research in Undergraduate History Classes. 
Ayers' pioneer work that combines GIS methodology in the digital history content $^{12}$.

Moreover, very interesting are the studies in the history of publishing that welcome the new technologies of geo-referencing ${ }^{13}$. The objective of this paper is to contribute in building a "geography of the educational book" and, by that, to increase the historical understanding of didactics. Geo-referencing information means in fact having a clear idea of the circulation of textbooks in the Kingdom of Italy.

Like all of the quantitative methodologies ${ }^{14}$, geo-referencing systems are also made up of various phases, preliminary to the final result and of great importance for their reliability and significance of elaboration. I believe that it is therefore necessary to indicate in synthesis the following practice, as an integral part of historical analysis.

After the choice of the software ${ }^{15}$, all of the inspectors' responses were reread and accurately coded, to be inserted in the GIS database. To connect these data to the territorial context, it was realized ${ }^{16}$ a vector map of the Kingdom of Italy allowing, in this way, to obtain their cartographic restitution. Even if the information is detailed, we believed it was necessary simplifying the overall picture by conducting the analysis province by province ( 69 at the time of the survey).

12 Edward L. Ayers, William G. Thomas, III, The Differences Slavery Made: A Close Analysis of Two American Communities, <http://www2.vcdh.virginia.edu/AHR/ $>$ (see also the presentation article: An Overview: The Differences Slavery Made: A Close Analysis of Two American Communities, “American Historical Review”, 108 (5), 2003.

13 See Fiona A. Black, Bertrum H. MacDonald, J. Malcolm W. Black, Geographic Information Systems: A New Research Method for Book History, "Book History”, 1998, 1; Fiona A. Black, Bertrum H. MacDonald, Using GIS for Spatial and Temporal Analyses in Print Culture Studies, "Social Science History", 24 (3), 2000.

14 G. Bandini, La storia dell'educazione e la sfida metodologica, Firenze, CET, 2005, pp. 15-92.

15 A very common and circulated application was chosen, ArcView GIS 3.2a (Environmental System Research Institute Inc., 1992-2000).

16 The vector map is the result of an adaptation of an actual map, modified respecting the division of provinces of the time. For convenience I used the detailed cartography of the volume of G. Pennesi, Atlante scolastico per la geografia fisica e politica, Roma, Istituto Geografico Italiano, 1894. 


\section{Inchiesta Bonghi (1875/75) Risposte Degli Ispettori}
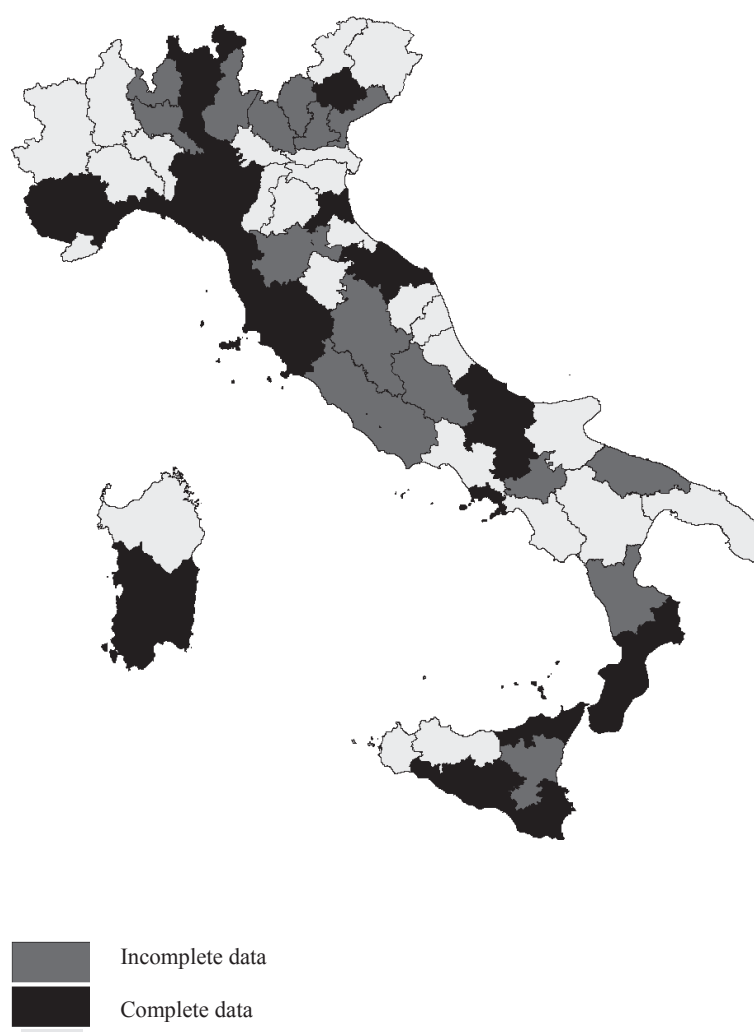

Incomplete data

Complete data

Missing data

Map 1 - Inspectors' responses.

As we can see from the Map n. $1^{17}$, even if we do not possess all of the inspectors' responses ${ }^{18}$, they are a good and adequately representative

17 Other maps for reasons of space cannot be included in this text, but can be checked on line, in <www.reseducationis.it> (in the section: Electronic resources for the history of education).

18 Provinces with complete responses: Ancona, Benevento, Bergamo, Cagliari, Caltanissetta, Campobasso, Catanzaro, Chieti, Cremona, Cuneo, Genoa, Agrigento, Grosseto, Livorno and Elba, Lucca, Massa and Carrara, Messina, Napoli, Parma, Pesaro and Urbino, Piacenza, Pisa, Ravenna, Reggio Calabria, Reggio Emilia, Siena, 
sample. Even in those cases of partial responses, generally, the missing fact/s is minor (one neighborhood is missing, for example) and therefore does not affect much the overall meaning.

Before examining the results of the geo-referenced analysis, it is worth highlighting that, for the specific characteristics of the source, the presence of various geography books (or with relevant parts of geographic topic) is surely underestimated with respect to reality: in some cases we know with certainty that the circulation was more extended (as reported on the citations in the historiography, for example), but since it is not possible to do a complete and reliable verification in all cases, it is more correct and more meaningful to limit ourselves to the recorded documents and their information.

The ministerial circular clearly explained that the inspectors needed to refer to the "more used" books: therefore the inspectors, having to refer to the circulating books in their specific areas, provide us with a general, certainly approximate, picture but of great interest. In other words, it is as if, with sociological methodologies, we interviewed today few representatives of specific cultural areas.

It is worth noticing that most textbooks don't simple target children, but they are distinctly directed at teachers: in some cases, as a matter of fact, there are some precise typographical directions that help reading. For example, at the beginning of some books, there is written "the part in small characters is only for teachers"; it is acknowledged, in other words, the teachers' poor preparation and the need to provide them a distinct educational help.

Since the quantitative aspects are always mixed with qualitative ones, such a relationship must always be kept in consideration. The way in which the inspectors send responses to the minister is in fact very indicative of their thought and it is interesting as much as the detailed information provided: some inspectors, for example, classify a part of textbooks under the item "geography" even if such an item was not expected neither in the ministerial circular nor in the current programs at that time (geography

Siracusa, Sondrio, Treviso. Provinces with partial responses: Aquila, Avellino, Bari, Brescia, Catania, Como, Cosenza, Firenze, Milano, Padova, Perugia, Roma, Venezia, Verona, Vicenza. Missing provinces: Alessandria, Arezzo, Ascoli Piceno, Belluno, Bologna, Caserta, Ferrara, Foggia, Forlì, Lecce, Macerata, Mantova, Modena, Novara, Palermo, Pavia, Porto Maurizio, Potenza, Rovigo, Salerno, Sassari, Teramo, Torino, Trapani, Udine. 
was, in fact, part of reading and of nomenclature ${ }^{19}$ ). The operation, therefore, reflected a particular interest for a discipline that was becoming important and with a specific identity of its own.

In sum, we can hence observe that, even without ministerial indications, specific textbooks for geography ${ }^{20}$ were used together with textbooks with explicit geographic contents. ${ }^{21}$ These aspects allow us to understand that geography had in fact already gained an informally important role in most elementary schools of the Kingdom of Italy, both in the north and in the south of the country.

There is no mention of any geographic atlas in the inspectors' responses, atlas that become a constant presence only at the beginning of 1900s. There are many reasons for this absence (mainly their cost), first among all the limited importance given to cartography in schools. In Italy, in reality, a very elegant cartographic production existed (that had adopted

19 The reference is to programs included in the regulation of September 15, 1860 and “Coppino's" programs, R.D. of October 10, 1867. See E. Catarsi, Storia dei programmi della scuola elementare (1860-1985), Firenze, La Nuova Italia, 1990; M. Civra, I programmi della scuola elementare dall'Unità d'Italia al 2000, Torino, Marco Valerio Editore, 2002. For Coppino's programs, see G. Bandini, La politica scolastica del ministro p.i. Michele Coppino e l'editoria fiorentina, in C. Betti (ed.), Percorsi del libro per la scuola fra Otto e Novecento. La tradizione toscana e le nuove realtà del primo Novecento in Italia, Acts of the Conference, Florence, February 21-22, 2003, Firenze, Pagnini, 2004, pp. 77-95.

20 Specific textbooks for geography are indicated in the provinces of Ancona, Bari, Benevento, Bergamo, Catanzaro, Chieti, Cosenza, Cremona, Cuneo, Genova, Girgenti, Grosseto, Lucca, Milano, Napoli, Pesaro e Urbino, Piacenza, Pisa, Reggio Emilia, Roma, Siena, Sondrio, Venezia, Verona, Vicenza.

21 Books with some geographic content are indicated in the provinces of Cagliari, Caltanissetta, Como, Livorno and Elba, Parma, Perugia, Ravenna. One of the most cited (as we will see in the next paragraph) was the Libro completo by Giuseppe Bosio and Carlo Pozzi. For example: Libro completo per gli allievi e per le allieve della $4^{\circ}$ elementare urbana e rurale, Tipografia C. Favale e Compagnia, Torino, 1872, 419 p. (the last ed. is from 1910). The contents are: 1. readings on political economy, i.e. social notions on the effectiveness of human work, on Instruction, Ownership, Capital, the Government and the taxes, the Association - Geography, economic, statistical and historical notions of Italy and of the 69 regions of the kingdom - a brief mention to the reigning dynasty of Savoy in relation to the present Italian nationality, of which the noble descent is the core; 2 . the tales of Sacred History in the $4^{\text {th }}$ class; 3 . the Grammar Book with topics and rules of composition; 4. Arithmetic; 5. The first notions of Geometry and drawing; 6. The decimal metric System. 
the geodetic principles at the beginning of the $1800 \mathrm{~s}^{22}$ ), but geography was not considered as an autonomous science with clear objectives and methodologies of application.

The change in the Italian geography's perception occurred in the second half of the 1800s, with the institutionalization of the discipline in the academic context and thanks to the German models 'strong influence 23 , within a period of close contact between the two cultures, also from a political and an economic standpoint ${ }^{24}$. This is the reason why the first world atlases are translations from German and, as a matter of fact, they present a German-centered vision of the world ${ }^{25}$. One example is the great 1908 Stieler Atlas that solicited to create an all-Italian cartographic product, "fruit of an original process", as stated by Roberto Almagià ${ }^{26}$.

The secondary schools' textbooks were the first to acknowledge these changes and to place cartography permanently within geography. The primary schools' textbooks followed, with a clear delay, the secondary schools' ones, much richer and more structured. To confirm this last point, it is necessary to consider the important role of the national programs for primary schools: the 1860 programs did not consider geography as an autonomous subject and included the physical geography among the "reading sections' basic" themes ${ }^{27}$. A mention to cartography was included in the Coppino programs in 1867, in which it is suggested that "it would be convenient to teach simple geography through reading books and maps" ${ }^{28}$.

22 I. Luzzana Caraci, Storia della geografia in Italia dal secolo scorso a oggi, in G. Corna Pellegrini (ed.), Aspetti e problemi della geografia, Settimo Milanese, Marzorati, 1987, pp. 48-49.

23 Ibid., pp. 53-56.

24 G. Corni, Il modello tedesco visto dall'Italia, in A. Giovagnoli, G. Del Zanna (eds.), Il mondo visto dall'Italia, Milano, Guerini, 2004, pp. 34-54.

25 E. Boria, Cartografia e potere. Segni e rappresentazioni negli atlanti italiani del Novecento, Torino, Utet, 2007, pp. 66-89.

26 Quoted in Ibid., p. 69.

27 Programmi per la scuola elementare annessi al regolamento del 15 settembre 1860 , in Codice dell'Istruzione secondaria classica e tecnica e della primaria e normale, Torino, Seb. Franco e F., 1861, pp. 401-404. Broader explanations were dated in Istruzione ai Maestri delle Scuole Primarie sul modo di svolgere I Programmi approvati col R. Decreto 15 settembre 1860, in Ibid, pp. 415-436.

28 Istruzioni e programmi per l'insegnamento secondario classic e tecnico, normale e magistrale, ed elementare nelle pubbliche scuole del Regno, in Gazzetta Ufficiale del Regno d'Italia, supplement to the n. 291, October 24, 1867. 
This is why only a few examples of atlases existed for primary schools, both in the pre-unification period ${ }^{29}$ and in the two decades after it $^{30}$.

Geography joined the list of school subjects only in the Gabelli program of 1888 with cartography ranking highly: teachers were instructed on "the most important thing that is to lead students, with practical exercises, in understanding what a map is and to use it" ${ }^{\prime 3}$. From this moment on the programs will emphasize the exceptional ideological effectiveness of geography, seen as suitable didactic instrument for the popular school for its patriotic and ideological goals. The instrumental nature is certainly common to many school subjects, but in a particular way, to geography and history, both organized in constructing a single and cohesive vision of the nation and of its future, as part its own history and its natural development $^{32}$. The most interesting example, to this purpose, is the use of the concept "Italian natural borders" that circulates in textbooks in homage to the growing nationalism at the end of the century ${ }^{33}$.

29 Manuale di geografia universale contenente i principia della geografia matematica, fisica, e politica [...] corredata di un atlante geografico ad uso delle scuole primarie, dei college e licei, Venezia, stab. Tip. di Gir. Tasso, 1841; Atlante elementare di geografia ad uso dei principianti di questa scienza, preceduto da alcune tavole di cosmografia, utili alla piena intelligenza dei rudimenti che intorno al sistema planetario generalmente espongonsi nelle scuole nostre, Firenze, Vincenzo Batelli e Compagni, 1846.

30 F. C. Marmocchi, Piccolo atlante geografico per uso delle scuole elementari composto di 22 carte, Torino, Guigoni, 1860; Atlante geografico, ad uso delle scuole elementary, ginnasiali e tecniche, designed and carved by V. Steeger, direct for the scientific part by professor Giuseppe De Luca, Napoli, 1869; Nuovo atlante geografico ad uso delle scuole primarie e secondarie, designed under the direction of the engineer Luigi Hughes from G.E. Fritzsche, Roma, G.B. Paravia, 1886-1887, 2 v.

31 Relazione a S.M., sulla riforma dei programmi per le scuole elementary, in Appendix of Enzo Catarsi, Storia dei programmi della scuola elementare (1860-1985), Firenze, La Nuova Italia, 1990, pp. 205-219.

32 See the interesting considerations of P. Bianchini in I testi di lingua italiani prima e dopo l'Unità, in G. Chiosso (ed.), TESEO. Tipografi e editori scolastico-educativi dell'Ottocento, Milano, Editrice Bibliografica, 2003. On the teaching of history: A. Ascenzi, Tra educazione etico-civile e costruzione dell'identità nazionale. L'insegnamento della storia nelle scuole italiane dell'Ottocento, Milano, Vita \& Pensiero, 2004.

33 For a global vision of these problems, that for reasons of space here it is possible only to mention, see E. Squarcina, Didattica critica della geografia. Libri di testo, mappe, discorso geopolitico, Milano, Unicopli, 2009. Many interesting observations, above all on geographic publishing in the fascist period, in E. Boria, Cartografia e potere. 


\section{The Diffusion of Geography Books after the Unification of Italy}

The controversial identity of geography for elementary schools gives way to a series of judgments and evaluations by the inspectors: they sometimes criticize textbooks very severely on the basis of few considerations about geography and its teaching. Meanwhile, it is necessary to notice that after unification there is already a common didactic practice that consists of using few or no books and in dictating the contents for most of the time. One supporter of this practice is the inspector from Messina: with an original but contradictory argument he sustains that only teachers can guarantee the respect of scientific correctness: he says "as a matter of fact, the textbooks, to meet the students' intelligence often forget the exactness of scientific definitions, and sometimes give definitions that are not exact. From that, I assume, and I have the deepest conviction, elementary science books must not be put in the students' hands, except as a textbook for teaching language and nomenclature; the books should be the same for all schools, at least in the same region: all the other parts of teaching required by the programs, should be provided via voice by the teacher, who would summarize, and then dictate the contents in synthesis to the students" ${ }^{\prime 34}$. This perspective is effectively summarized by the phrase "books are nothing, the teacher is everything" ${ }^{35}$ that embodies also the resistance against the new pedagogical methodologies and the growing pressure of the publishing market that in fact carried them.

The inspector of Naples, on the contrary, supported the textbooks' validity, in connection with the most updated pedagogical discussions of the time (in particular after the pedagogical congress that was held in Naples

Segni e rappresentazioni negli atlanti italiani del Novecento, Torino, Utet, 2007. On the specific question of boundaries see the essays of U. Fabietti, La costruzione dei confine in antropologia and A. M. Banti, Corpi e confini nell'immaginario nazional-patriottico ottocentesco, in S. Salvatici (ed.), Confini. Costruzioni, attraversamenti, rappresentazioni, Soveria Mannelli, Rubbettino, 2005; A. Pastorie (ed.), Confini e frontiere nell'età moderna: un confronto fra discipline, Milano, FrancoAngeli, 2007.

34 Relazione by Clemente G. Fenoglio, inspector of the surroundings of Messina (ACS, CSPI, b. 4, Scigliano, November 23, 1874, prot. n. 198).

35 See Relazione by Giuseppe La Guardia, inspector for the areas of Cosenza and Paola (ACS, CSPI, b. 4, Scigliano, April 14, 1875, prot. n. 215). 
a few years earlier ${ }^{36}$ ). In his opinion a book "should embrace everything that deals with the individual's culture, but in what is appropriate for the individual person, his age, gender, and social condition" ${ }^{37}$.

In the debate pro/against the textbooks there are also oppositions against the ministerial demands of asking the school board's opinion on the textbooks' adoptability. For example, in Siena, inspector Ferrari did not want uniformity of textbooks (that instead the ministers seemed to like). In fact, he stated "this variety [of textbooks] instead of hurting the growth of instruction, have the opposite nature of reducing pedantry, which unfortunately some of the same pedagogists are looking to keep, and of establishing a criteria on which we can understand which are the best books to adopt in class; it is only by using a book that we can infer if a book is good or not." 38 .

Who wrote geography books for primary schools, that is the geography for people? We can find some interesting typologies of educational author (on which we will focus in the next paragraph): there are in fact some teachers, in particular Giuseppe Bosio and Carlo Pozzi, whose texts have a great circulation, but also some historians and geographers like Luigi Schiaparelli, Ferdinando de Luca and, above all Ercole Ricotti, who in 1847 in Turin was the first professor of geography in an Italian

36 Atti del VII Congresso pedagogico italiano pubblicati a spese del municipio e per cura del prof. Filippo Delli Franci, vice-segretario generale del congresso, Napoli, Tip. Francesco Giannini, 1871.

37 "So it would be desirable that those notions the ordinary child is obligated to research in special books, such as geography, history etc., were contained in the reading books for elementary schools, both because those notions are not considered as a special mnemonic teaching, and not to confuse the scholar with many volumes that could slow down his attention". See Relazione by F. [Pelli], inspector of Naples and its province (ACS, CSPI, b. 4, Naples, February 15, 1875, prot. n. 50). See Atti del VII Congresso Pedagogico Italiano, Napoli, Stab. Tip. Francesco Giannini, 1871. The geographic theme is proposed as a separate topic in the X Congress of Palermo and, above all, discussed in the XI of Rome (see Atti del X Congresso pedagogico italiano, Palermo, Gaipa, 1877; Atti preliminari dell'XI Congresso pedagogico italiano e della VI Esposizione didattica che avranno luogo in Roma nel 1880, Roma, Tip. E. Sinimberghi, 1879; Atti dell'XI Congresso pedagogico italiano e della VI Esposizione didattica, Roma, tip. E. Sinimberghi, 1881).

38 Relazione of Ferrari, Inspector of the province of Siena (ACS, CSPI, b. 4, Siena, November 7, 1874). 
university ${ }^{39}$; some authors can be considered roughly as "pedagogists", in a particular, Antonino Parato and Giovanni Scavia ${ }^{40}$.

By studying the Bonghi survey, it is possible to see in detail the textbooks' circulation, beginning from the smaller and limited circulation. Due to the space, only the smallest and essential information will be provided here, postponing to later discussions the detailed and elaborated analysis of the authors' interesting biographies (known only in small parts because there are many minor authors who do not appear in the main biographical works ${ }^{41}$ ).

Lorenzo Bernardo Amerigo is the most popular author in the province of Genoa ${ }^{42}$; the Breve corso di geografia by Eugenio Comba is used in Vicenza and published for many years, with new editions and a reprint

39 In 1847 it had the title of professor of modern history and chair of geography and statistics (he became tenured in 1857). See A. De Gubernatis, Ricordi biografici. Pagine estratte dalla storia contemporanea letteraria italiana in servigio della gioventù, Appendice, Firenze, 1876.

40 With the term "pedagogists", we indicate in a concise way (even if not precise) the textbooks' authors who, other than carrying out educational activities, are part of the pedagogical debate of the time. They are didactic magazines' promoters, officials and inspectors of the education minister, educational executives. The term can appear inaccurate today, but it was fluently used to highlight the educational effort of these people at that time. For reference, by the way, see the biographical dossier regarding Scavia: A. De Gubernatis, Dizionario biografico degli scrittori contemporanei, Firenze, Le Monnier, 1880, vol. 2. On Parato and Scavia one reads above all G. Chiosso, I giornali scolastici torinesi dopo l'Unità, in G. Chiosso (ed.), Scuola e stampa nell'Italia liberale. Giornali e riviste per l'educazione dall'unità a fine secolo, Brescia, Editrice La Scuola, 1993. For an overall picture of the problems in educational publishing, see in particular C. Betti, Arte educativa e scienza pedagogica nella manualistica magistrale and G. Chiosso, Il libro per la scuola tra ottocento e novecento, both in G. Chiosso (ed.), TESEO, cit.; M.C. Morandini, Scuola e nazione. Maestri e istruzione popolare nella costruzione dello Stato unitario (1848-1861), Milano, Vita \& Pensiero, 2003.

41 The K.G. Saur's Biographical Archives and the Dizionario Biografico degli Italiani were mainly examined.

42 L. B. Amerigo, Elementi di geografia. Secondo il programma governativo della terza e quarta classe elementare, 5. ed. riveduta ed aumentata, Tip. del R. I. de' Sordo-muti, Genova, 1873, 47 p. (4. ed., Genova, Stamperia Sociale, 1869; 9. ed., Genova, Lanata, 1880). From now on the bibliographical references will be indicated by indicating the closest edition to the survey that was possible to find and read; when possible, the first known edition and the last will also be indicated. They are the concise indications that to be clarified and defined, would require a specific critical and comparative study of the different editions. 
well beyond the beginning of $1900 \mathrm{~s}^{43}$. It is interesting to note that in the year preceding the survey, this author published a guide (one of the first in Italy) on teaching geography ${ }^{44}$, in which there are explicit references to Karl Ritter's works, to the usefulness of didactic aids such as globes and atlases, to the necessity of an experimental dimension of lessons ${ }^{45}$. He was well-known above all for his textbooks dedicated to the secondary schools, which are considered among the best for the technical and normal schools by the Commission of $1883^{46}$.

Still in Vicenza, inspector Rota points out two other authors: Innocenzo Regazzoni, professor of natural history of the Liceo Reale Volta of Como (author of texts on natural sciences) ${ }^{47}$ and Andrea Covino ${ }^{48}$. This

43 E. Comba, Breve corso di geografia teorico-pratica corredato d'esercizi d'applicazione ad uso delle scuole elementari superiori e del primo anno delle scuole ginnasiali. Operetta premiata con medaglia dal Congresso Pedagogico di Venezia, 1872, ed all'Esposizione Universale di Parigi, 1878, G.B. Paravia and comp., 1886, 108 p. The inspectors referred to the fourth edition (Paravia, 1874). In 1920 Paravia publishes the first reprint of the new edition.

44 E. Comba, Guida per lo insegnamento della geografia, operetta corredata di carte geografiche e contenente la soluzione ragionata dei quesiti proposti nel breve corso e nel nuovo compendio di geografia, oltre una serie di nuovi esercizi colle loro risposte, Torino, G.B. Paravia and comp., 1873, 304 p.

45 Ibid., pp. 3, 25 and 33.

46 MPI, Commissione sopra i libri di testo per le scuole elementari e popolari, per le scuole tecniche e normali, per gli istituti tecnici e per le scuole ginnasiali e liceali. Relazione generale a S.E. il Ministro, presidente del Consiglio Superiore della Pubblica Istruzione, Roma, Ippolito Sciolla, 1885, p. 14 (Rome, October 13, 1883, general supervisor Anton Giulio Barrili).

47 Innocenzo Regazzoni (1823-1899) is the teacher at the Volta High School in 1865 (according to how much Annuario Scientifico ed Industriale, Rivista annuale delle scienze d'osservazione e delle loro applicazioni in Italia e all'estero reports, Second year, 1865, Milano, Editori della Biblioteca Utile, 1866, p. 280) and famous for his important palethnological collection. In reality it is not clear if he has written books for elementary schools: see I. Regazzoni, Nozioni elementari di scienze naturali esposte secondo I programmi e le istruzioni ministerial ad uso delle scuole tecniche magistrali e normali, 5. ed. con note ed aggiunte, Como, Tip. C. Franchi, 1873, 460 p. (2. ed. 1867; 20. 1891).

48 Andrea Covino published various textsbooks for primary and secondary schools. Probably the inspector refers to the Nuovo saggio di geografia secondo I programmi governativi colle più recent indicazioni, Parte prima per le classi elementari superiori maschili e femminili pel $1^{\circ}$ anno delle scuole tecniche e pel $1^{\circ}$ e $2^{\circ}$ delle classi normali e magistrali, Torino, Paravia, 11. ed.1874, 61 p. (22 ed. revised by the author, 1888). The second part of the volume was dedicated to the secondary schools: Parte 
last one was pointed out as the most popular author in the province of Cuneo and, probably, in the province of Turin, but unfortunately we do not possess enough data on this. Covino was in fact a geographer and hiker, professor at the technical institute of Turin.

Among the authors with limited circulation, in central Italy, there are Gaetano Branca's works (in the province of Siena ${ }^{49}$ ) and a very old textbook, used in Pisa and Volterra, the Elementi di geografia ad uso delle scuole pie ${ }^{50}$ (included from 1849 among the obligatory books in the Este family States $\left.{ }^{51}\right)$.

In southern Italy, in the province of Naples, three authors are prevalently used: Francesco Lang ${ }^{52}$, Giuseppe Morano ${ }^{53}$ and Pietro Pacella ${ }^{54}$.

At this point we can move to a group of authors with wider circulation (as far as nine provinces). The first is Luigi Schiaparelli, from Piedmont,

seconda, questo volumetto risponde al programma del $2^{\circ}$ e $3^{\circ}$ anno delle scuole tecniche, e serve di complemento alle nozioni di geografia richieste nelle classi normali e magistrali. Covino wrote a guide of Turin (Quelques heures à Turin, Torino, Favale e Comp., 1873, 52 p.) and an interesting trip to Italy on the trail of Dante (Descrizione geografica dell'Italia, ad illustrazione della Divina Commedia di Dante Alighieri, accompagnata da una carta speciale, Asti, Raspi, 1865, 54 p.).

49 Gaetano Branca, already a professor in the Military College of Milan, Geografia elementare proposta alle scuole primarie, seconda edizione riveduta ed accresciuta dal professore Guido Cora, Ermanno Loescher, Torino, 1872, 152 p. (1. ed. 1868; 4. ed. revised by Luigi de Marchi, 1879).

50 Elementi di geografia. Ad uso delle scuole pie, Firenze, Tip. Calasanziana, 2. ed., 1834, 143 p. (the 16. Has the titration Elementi di geografia ad uso delle scuole pie con un breve compendio di sfera armillare, 1875, 198 p.).

51 Regolamento generale per le scuole ginnasiali e elementari degli Stati Estensi, approved by S.E. the Minister of the Interior, Modena, Tipografia Carlo Vincenzi, 1849, p.11.

52 F. Lang, Geografia elementare ad uso delle scuole d'Italia, Napoli, Tip. del Plebiscito, 1864,2 . ed., $160 \mathrm{p}$.

53 G. Morano, Elementi di geografia ad uso delle classi elementari, Napoli, A. Morano, 1870 , pp. 63 (the first edition is probably from 1863, the last from 1885).

54 P. Pacella, Primi elementi di geografia moderna ad uso delle classi elementari superiori, 5. ed., Napoli, De Angelis, 1873, 104 p. (19. ed. 1897). By the same author: Regole pratiche intuitive di orientazione ad uso delle scuole elementari e preparatorie normali secondo i più recenti programmi governativi, Operetta approvata dal consiglio provinciale scolastico di Napoli, seconda edizione con 23 figure intercalate nel testo, Torino, G. B. Paravia e Comp., 1890, 28 p.; Vocabolario geografico universale dei principali nomi di geografia moderna e dei paesi italiani ossia prontuario generale di geografia fisica e politica, Napoli, Vincenzo Morano, 1882, 758 p. (2. ed. 1888). 
historian and geographer, professor of ancient history at the university of Turin: his textbooks were the most used in the provinces of Ancona, Lucca and Pisa. ${ }^{55}$

Silvestro Bini's books (provinces of Chieti, Grosseto and Vicenza ${ }^{56}$ ) also have a fair circulation. In this case, he is an author with some specific academic competences and not a polygraph who wrote texts of diverse nature. In the textbooks for elementary schools this considerable presence of specialists is important because it indicates the difficulty of handling issues on geography (as an example, cosmography) and it is connected to the changing in the subject in the 1800 s, and to the different methods of conceiving the environmental study. It is worth mentioning that Bini's books for the technical and normal schools (together with Comba's, Borrelli's and Hughes' works) were greatly appreciated. ${ }^{57}$

Ferdinando De Luca's works ${ }^{58}$ (provinces of Bari, Benevento, Catanzaro, Cosenza, Naples, and Pisa) also had a decent circulation: he never had academic positions, but he concentrated his studies, for long time and with original works, on geographic issues. In a particular way, it is worth mentioning his focus on the methodological and didactic issues (for example with the insertion of semimute maps ${ }^{59}$ ) that make them almost unique in the first half of $1800 \mathrm{~s}^{60}$.

55 The books of Luigi Schiaparelli were specifically directed to the secondary school, except for the Principii elementari di geografia esposti in forma di dialogo secondo gli ultimo programmi governativi per le classi elementari superiori, 12. ed. interamente riordinata dall' Autore sulla 13. ed. del Manuale di geografia e statistica, Torino, Paravia, 1880, 73 p.

56 S. Bini, Lezioni elementari di geografia per le classi elementari, Torino, Paravia, 9. ed. 1871 (15. 1877).

57 MPI, Commissione sopra i libri di testo per le scuole elementari e popolari, per le scuole tecniche e normali, per gli istituti tecnici e per le scuole ginnasiali e liceali. Relazione generale a S.E. il Ministro, presidente del Consiglio Superiore della Pubblica Istruzione, Roma, Ippolito Sciolla, 1885, pp. 14-15.

58 F. De Luca, Istituzioni elementari di geografia (antica e moderna) naturale, topografica, politica, astronomica, fisica e morale, ordinata con un nuovo metodo in otto periodi, Napoli, Stamperia del Fibreno, 20. ed., 1861, 384 p. (1. 1838?). The text was in reality dedicated to the secondary schools.

59 On Ferdinando De Luca see the homonymous voice of M.B. D'Ambrosio, in Dizionario Biografico degli Italiani, vol. 38, 1990, pp. 334-337.

60 F. Fulvi, Lineamenti di storia della geografia. Dalle origini ai giorni nostri, Torino, Giappichelli, 1988, pp. 43-44. 
We find a very different approach in the works of the prolific Florentine author Silvio Pacini (the most popular and used in the provinces of Bari, Chieti, Grosseto, Reggio Emilia and Siena). In his textbooks, there is a strong desire to simplify and adapt, as it is well illustrated by the question of maps. In the paragraph "what are geographic maps" he explains the question in few lines: "how does one draw the Earth? There is no reason to be dismayed by this: we draw the earth on paper the same way we draw portrait or any other landscape" ${ }^{\prime 1}$. Maps do not appear in his books, as they do in most of the other authors' works we are examining ${ }^{62}$ (who rarely present them and without any indication of scale). That can appear very strange because the link between geography and cartography had already been very tight since the previous century; the cultural environment of Florence at that time, furthermore, presented Pasquale Villari's positivistic approach, and, as far as geography, Bartolomeo Malfatti's and, above all, Giovanni Marinelli's, his successor as chair of the Istituto di Studi Superior $^{63}$. However, besides what said on the atlases, we need to emphasize that the authors for infancy were resistant to changes, because of their lack of specific studies and in the adherence to a traditional and very common concept that considered geography as connected to history, a sort of auxiliary discipline, with narrative and descriptive structure, focused on the human presence on the territory only for its artistic and urban realizations. The particular tendency in the elementary didactic toward the narrative approach gained a humanistic approach that basically influenced later all the other subjects.

Another very popular author is the teacher Giovanni Castrogiovanni (in the provinces of Cagliari, Chieti, Cosenza, Parma, Ravenna), famous

61 S. Pacini, Primi elementi di geografia, Firenze, Mariani, 1861, 31 p. (8. ed. 1889).

62 It is worth noting that a famous and important work as the Nozioni compendiose di geografia by Ercole Ricotti does not present any maps. Only in the revised version by G. Roggero, in 1888, indicates the necessity of maps, at least murals, "teachers should always have maps in their hands" (see E. Ricotti, Nozioni compendiose di geografia, 20. edition entirely revised and enhanced by Captain G. Roggero, professor of Geography in the Military College of Milan, who kept the original forms provided by its author, Milano - Dabalà and Casaccia, Torino - G. B. Paravia, 1888, p. 3).

63 For these aspects and for a general placement see by now the classic L. Gambi, Uno schizzo di storia della geografia in Italia, in Id., Una geografia per la storia, Torino, Einaudi, 1973, pp. 3-37; I. Luzzana Caraci, Storia della geografia in Italia dal secolo scorso a oggi, in G. Corna Pellegrini (ed.), Aspetti e problemi della geografia, Settimo Milanese, Marzorati, 1987, pp. 45-94. 
for his elementary education texts ${ }^{64}$ that, despite being very popular, were probably not of a very high quality. For example, Luigi Selmi, inspector for the province of Ravenna, despite indicating him as the most used author, presents a severe critique of his works: "Castrogiovanni's readings for the upper classes are a mixture of difficult and different subjects: physics, psychology, natural sciences, rights and duties, history and geography, organised in such a strange and bizarre way, that it doesn't seem to be an elementary school book, but rather a summary of the main notions on already studied and discussed subjects" ${ }^{\prime 65}$.

Giuseppe Bosio and Carlo Pozzi are also primary school teachers and their Libro completo per gli allievi e le allieve had an almost national circulation (provinces of Benevento, Bergamo, Cagliari, Chieti, Como, Cremona, Livorno and Elba, Perugia, and Sondrio) and went through numerous editions. ${ }^{66}$ There are, in fact, many positive comments and especially because the book focused on the "elementary notions of human and Christian knowledge" and on the farmer's needs, it can be of great use in rural schools ${ }^{67}$. The geographic sections of these texts have historical and physical-descriptive character (not exempt from rough errors ${ }^{68}$ ), in line

64 G. Castrogiovanni, Letture secondo il programma legislative per la terza e quarta elementare, Torino, Paravia, 16 ed., 1874, 312 p. (9. ed. 1868; 25. ed. 1885).

65 Relazione di Luigi Selmi, inspector for the province of Ravenna (ACS, CSPI, b. 4, Ravenna, January 9, 1875, prot. n. 8).

66 G. Bosio, C. Pozzi, Libro completo per gli allievi e per le allieve della $4^{\circ}$ elementare urbana e rurale, Tipografia C. Favale e Compagnia, Torino, 1872; the Libro completo is in various volumes dedicated to second, third, fourth, and fifth classes (and also for the sixth, after 1905). These volumes, despite their little presence in specialized databases such as Clio (only three times) had several editions; for example the Libro completo per la terza classe elementare rurale arrives to 81editions in 1906.

67 Relazione of Filippo [Sala], inspector for the areas of Perugia and Orvieto (ACS, CSPI, b. 4, Perugia, March 5, 1875, prot. n. 130).

68 For example: "Liguria, is between the Adriatic and the region that goes from the Varo river in Genoa, called Riviera di Ponente" (Giuseppe Bosio, Carlo Pozzi, Libro completo per gli allievi e per le allieve della $4^{\circ}$ elementare urbana e rurale, Tipografia C. Favale e Compagnia, Torino, 1872, p. 92). The rest dealt with a somewhat frequent situation. We can read, for example, what the Central Commission on Textbooks thought about the Sillabari (grammar and spelling books): "it is painful to find in every page of these spelling and composition books, many varieties of language, grammar and syntax; mistaken verbs, prepositions without syntactical and logical link, invented nouns, foreign idioms, dialectal words adjusted in Italian ending and with Italian meaning (Relazione della Commissione Centrale dei libri di testi a S.E. il Ministro, "Giornale della libreria della tipografia e delle arti e industrie affini Anno VIII, 1895 p. 377). 
with a geography "based on lists", very traditional in both scientific and didactic areas.

The last group, not certainly for importance, deals with those books with a clear national circulation, in line with a changing trend at the end of the 1800s (together with transformation of publishing in a more industrial sense $^{69}$ ). In this group, there are well known authors such as Giovanni Scavia with two texts of specific geographic interest: the Prime nozioni di geografia and L'uomo e l'universo ${ }^{70}$ (in the provinces of Ancona, Cosenza, Cuneo, Benevento, Bergamo, Genoa, Girgenti, Milan, Pesaro and Urbino, Rome, Sondrio, Verona, Vicenza).

Antonino Parato's textbooks are very similar, for structure and content, to Scavia's ones and they are also very popular (in the provinces of Cuneo, Cosenza, Milan, Rome, Parma, Perugia, Piacenza, Sondrio, Venice, Verona, Vicenza), probably also because of Parato's ministerial roles. It is worth underlining that in the index of Cielo e terra ${ }^{71}$, we can find topics of geographic character (the universe, the four seasons, astronomy, the earth surface, notions of physics, notions of geography, etc.) organized according to a consolidated didactic tradition, and showing evident linguistic-poetics elements (for example, there are poems about dawn and sunrise) and moral approaches ${ }^{72}$. Talking about the four seasons, we can

69 G. Turi (ed.), Storia dell'editoria nell'Italia contemporanea, Firenze, Giunti, 1997.

70 G. Scavia, Prime nozioni di geografia secondo il programma della quarta classe elementare con una breve descrizione delle capitali dell'Europa, Torino, Vaccarino, 1873, 118 p. (1. ed. 1863?); G. Scavia, L'uomo e l'universo. Letture per la terza classe elementare, Torino, Tip. Scolastica, 1860, 160 p. (in 1893 it is published with Bartolomeo Rinaldi's revisions).

71 A. Parato, Cielo e terra. Quarto libro di letture proposto ai fanciuli delle scuole elementari superiori d'Italia da Antonino Parato e contenente le prime nozioni di Cosmografia, Geografia, Fisica e Storia naturale secondo il programma governativo della 4 a classe coordinate al terzo libro sull'Uomo approvato dal Ministero, edizione stereotipa - ventesima ristampa arricchita di una carta geografica, G.B. Paravia e comp., Torino, 1875, $144 \mathrm{pp}$. Based on what was stated on the front page, the work was "chosen by the single provincial educational Councils in the year 1865-66 as textbook in the provinces of Turin, Florence, Genova, Alessandria, Novara, Cagliari, Sassari, Pavia, Bergamo, Brescia, Cremona, Lucca, Siena, Pisa, Modena, Parma, Piacenza, Bologna, Forlì, Ravenna, Ancona, Perugia, Caserta, Avellino, Teramo, Aquila, Molise, Basilicata, Bari, Lecce, Cosenza, Trapani"; in 1868-69, there were other additions in Catania, Cuneo, Como, Sondrio, Girgeni, Udine, Mantova, Massa and Carrara, Milan and Venice.

72 F. Cambi, La pedagogia Borghese nell'Italia moderna 1815-1970, Firenze, La Nuova Italia, 1974. 
read: "how are the sky and the countryside in winter, and what can we see? What happens to the birds? And what about the streams and the rivers? [...] Tell me of that poor abandoned child seen on the street in January. Tell me of that poor blind boy seen in the square. Tell me of that cripple man met at nightfall. Who will you give help when you grow up?"73

At the end of this list of textbooks, there is Ercole Ricotti, probably the most important model scientifically and didactically speaking in the nineteenth century (his book was the most used in the provinces of Ancona, Bari, Cosenza, Cremona, Cuneo, Genoa, Girgenti, Lucca, Pisa and Volterra, Siena ${ }^{74}$ ). Among the comments on his volume, we read, for example, what the inspector of Genoa writes: "what is important in this book is the frank and clear wording, brief but at the same time complete, necessary and varied instruction, statistical measure, habits and customs. It is very useful for those people living in port cities, where one could easily begin the career of navigator". ${ }^{75}$

\section{Educational Culture and Geography: the Models of Reference}

At this point, I believe it is useful to draw a general picture by identifying the most popular textbooks for elementary schools, whose production continues (with different result) in the 1900s.

The first consideration to do is on the variety of teaching models, as by the study in primis of the textbooks: there is not, for example, a direct and immediate relationship between the academic culture of a specific subject and what is taught in school (and how it is taught). As far as the geographic studies, in particular, we can indicate more evident variables in time which will end up creating, by encountering and clashing with each other, a particular educational culture, with its own distinctive characteristics. In the same way there is not always a cause and

73 A. Parato, Cielo e terra. Quarto libro di letture proposto ai fanciuli delle scuole elementari superiori d'Italia, G.B. Paravia e comp., Torino, 1875, p. 14.

74 E. Ricotti, Nozioni compendiose di geografia, Milano - Dabalà and Casaccia, Torino G. B. Paravia, 1888.

75 Relazione di Giacinto Bianchi, inspector of the surroundings of Genoa, Chiavari and Levante (ACS, CSPI, b. 4, Genoa, December 20, 1874, prot. n. 141). 
effect relationship between the institutional strategy (represented above all by the national programs and by the instructions for teachers) and the contents of the published books. The ministerial regulation is certainly an aspect of great importance, but sometimes greatly overrated with respect to its effective incidence. As a matter of fact, the effectiveness of the mostly prescriptive indications given after the unification of Italy to regulate and to standardize teaching, is very variable in the different territorial contexts: as far as geography is concerned, we can observe how the textbooks are different from the contemporary programs, and in some cases, they anticipate certain important aspects (for example regarding the patriotic nature of teaching).

The textbooks effectively used in the schools after unification (and not simply those in the lists of adoptable books), are structured differently according to the authors' competences and their links both with the educational world and with the scientific world. A first group of books for elementary schools, significantly present but not very numerous, could be defined as the expression of a scientific model (or scientific-academic, when geography is part of university teaching). Two other groups of textbooks extensively diffused and influential on the teaching methodologies, are those written by "pedagogists" and those written by teachers. These last ones are part of a steady tradition of local authors who write their own notes for lessons and publish them in small printing houses that assure a limited, but sometimes lasting circulation. This model of didactic writing, in many parts very similar, is surely the closest to the normative-institutional demands and the most sensitive to rhetorical and ideological demands that are constantly addressed to schools and teachers.

The three models of textbooks, here briefly outlined, interact in various way among them and also with the educational production for the secondary school: as a matter of fact, in many cases the authors write above all for the secondary schools (it is the case of Luigi Schiaparelli, for example) and the books for primary schools are so the result of an operation of strong reduction and adaptation of contents from the models of the secondary schools.

In addition to these three models, there is a fourth didactic style, "elementary", and of little circulation but very interesting for its original approach to the geographic issues: it deals with those books commissioned by the city of Florence to Collodi and based on a child's adventures, Giannettino, who brings the reader in identifying himself in the adventures 
of the middle-class brat in his discovery of the world ${ }^{76}$. In 1880 Collodi presented the famous Viaggio in Italia di Giannettino ${ }^{77}$, followed by La Geografia di Giannettino ${ }^{78}$, a small volume more suitable for the schools. Collodi's model, despite having a recognizable stylistic nature, from a didactic point of view is decisively more outdated than the educational productions of that time, in particular the books for secondary schools and the scientific growth of geography. It has in fact, a strongly narrative approach that contrasts with more updated scientific and didactic models. It suggests the idea of pleasantly educating through a geography that simply describe the places and the men that live there, in a continuous dialogue among the children who are on the trip, but without any real use of cartography and a limited insertion of physical nomenclature: in the places to study there are the population, the historical ruins, the monuments, the views, the landscapes and the art; places of interest and fascination. It is worth noting that, while among textbooks, this type of structure will soon disappear, it indeed presents a singular similarity with the typical narrative structure of tourist guides.

The guides will become an important and common presence in the 1900 s, through their courses, their selections and exclusions according to the "important things" to see and know model (by thus creating some real and true stereotypes of travel in contemporary age, very lasting and influential). As an example, let's consider the importance of numerous publications of the Italian Touring Club that began in the end of the 1800s and continued with many other publishing initiatives by thus cultivating a new publishing sector (for example, the Itinerari automobilistici d'Italia of the Automobile Club of Milan, in the1920s).

The various models of textbooks, therefore, have peculiar characteristics and in some cases opposite with respect to national programs. The books with a scientific structure of geography are, for example, excessive with respect to the programs and the children's capacities of learning: let's

76 F. Cambi, Collodi, De Amicis, Rodari: tre immagini d'infanzia, Dedalo, 1985, pp. 23-78; R. Dedola, Pinocchio e Collodi, Milano, Bruno Mondadori, 2002.

77 The first trip of Giannettino was published in 1880, followed by two other parts (Collodi, L'Italia superiore, vol. 1, Firenze, Paggi, 1880, 320 p.; L'Italia centrale, vol. 2, Florence Paggi, 1883, 319 p.; L'Italia meridionale, vol. 3, Firenze, Paggi, 1886, 300 p.). They will be later put in a single volume by Ferruccio Ferroni (Firenze, Bemporad, 1902). It was recently published the facsimile reprint of the first edition in three volumes (Bergamo, Leading, 2006).

78 C. Collodi, La geografia di Giannettino, Firenze, Paggi, 2. ed., 1886, 97 p. 
consider those parts connected to cosmography and the high mnemonic learning required by the descriptive approach applied to all the regions of the world. Between the 1800s and 1900s there will be a close connection between the normative institutional programs and the scientific-academic geography, above all through a new focus given to cartography.

On the other hand, the model that results from the works of teachers (and also of "pedagogists") has some other characteristics: it demonstrates to be more sensitive to the real necessities of teaching children and anticipates the ideological connotations of programs that will insist on geography (matching with the story) as a vehicle of forming the citizen in the new idea of nation. They are books that strongly underline the theme of boundaries by emphasizing the Italian identity in relation to foreign nations. It is interesting noting that the teachers and the "pedagogists" show a patriotic spirit well before the official programs (in 1894) will make it obligatory: "History of Italy, Geography, Laws and duties of the citizen. This teaching will provide an education according to the needs and the aspirations of the new nation of Italy; it wants to convey love for the country now free and great for virtue of philosophers and martyrs who have contributed to liberate it" ${ }^{\text {"79. }}$.

It is through these courses that geography will reach, also in the elementary schools, its specific role, not more subsidiary and subordinate with respect to history, but at the same level. Geography gains a special educational force, linked to the description of the nation, to cartography, and the boundaries: the image of the teacher in the chair with the mural map of Italy at his shoulders becomes one of the most immediately recognizable and strongly symbolic stereotypes of the school in the liberal age.

\section{Bibliography}

A. Ascenzi, Tra educazione etico-civile e costruzione dell'identità nazionale. L'insegnamento della storia nelle scuole italiane dell'Ottocento, Milano, Vita \& Pensiero, 2004.

79 In the appendix of E. Catarsi, Storia dei programmi della scuola elementare, cit., p. 228. 
E. L. Ayers, William G. Thomas, An Overview: The Differences Slavery Made: A Close Analysis of Two American Communities, "American Historical Review", 108 (5), 2003.

G. Bandini, La politica scolastica del ministro p.i. Michele Coppino e l'editoria fiorentina, in C. Betti (ed.), Percorsi del libro per la scuola fra Otto e Novecento. La tradizione toscana e le nuove realtà del primo Novecento in Italia, Acts of the Conference, Florence, February 21-22, 2003, Firenze, Pagnini, 2004, pp. 77-95.

G. Bandini, Contributo alla storia quantitative del libro scolastico: notizie su una ricerca in corso, "Bollettino CIRSE", 2005, 42, pp. 3-8.

G. Bandini, La storia dell'educazione e la sfida metodologica, Firenze, CET, 2005.

O. Boonstra, Barriers between historical GIS and historical scholarship, "International Journal of Humanities \& Arts Computing", 3 (1-2) 2009.

Fiona A. Black, Bertrum H. MacDonald, J. Malcolm W. Black, Geographic Information Systems: A New Research Method for Book History, "Book History", 1998, 1.

Fiona A. Black, Bertrum H. MacDonald, Using GIS for Spatial and Temporal Analyses in Print Culture Studies, "Social Science History", 24 (3), 2000.

E. Boria, Cartografia e potere. Segni e rappresentazioni negli atlanti italiani del Novecento, Torino, Utet, 2007.

J. Brown, Using GIS to Drive Research in Undergraduate History Classes.

F. Cambi, Collodi, De Amicis, Rodari: tre immagini d'infanzia, Dedalo, 1985, pp. 23-78.

E. Catarsi, Storia dei programmi della scuola elementare (1860-1985), Firenze, La Nuova Italia, 1990.

G. Chiosso (ed.), Scuola e stampa nell'Italia liberale. Giornali e riviste per l'educazione dall'unità a fine secolo, Brescia, Editrice La Scuola, 1993.

G. Chiosso (ed.), TESEO. Tipografi e editori scolastico-educativi dell'Ottocento, Milano, Editrice Bibliografica, 2003.

M. Civra, I programmi della scuola elementare dall'Unità d'Italia al 2000, Torino, Marco Valerio Editore, 2002.

G. Corni, Il modello tedesco visto dall'Italia, in A. Giovagnoli, G. Del Zanna (eds.), Il mondo visto dall'Italia, Milano, Guerini, 2004, pp. 34-54. 
A. De Gubernatis, Dizionario biografico degli scrittori contemporanei, Firenze, Le Monnier, 1880, 2 voll.

R. Dedola, Pinocchio e Collodi, Milano, Bruno Mondadori, 2002.

F. Fulvi, Lineamenti di storia della geografia. Dalle origini ai giorni nostri, Torino, Giappichelli, 1988.

L. Gambi, Una geografia per la storia, Torino, Einaudi, 1973.

K. K. Kemp, What can GIS offer history?, "International Journal of Humanities \& Arts Computing", 3 (1-2) 2009.

I. Luzzana Caraci, Storia della geografia in Italia dal secolo scorso a oggi, in G. Corna Pellegrini (ed.), Aspetti e problemi della geografia, Settimo Milanese, Marzorati, 1987, pp. 45-94.

M. C. Morandini, Scuola e nazione. Maestri e istruzione popolare nella costruzione dello Stato unitario (1848-1861), Milano, Vita \& Pensiero, 2003.

J. B. Owens, Toward a Geographically-Integrated, Connected World History: Employing Geographic Information System (GIS), "History Compass", 2007, 5/6.

Pinol J.-L., Les atouts des systems d'information géographique - (SIG) pour "faire de l'histoire" (urbaine), "Histoire Urbaine", 26, 2009.

A. Pastorie (ed.), Confini e frontiere nell'età moderna: un confronto fra discipline, Milano, Franco Angeli, 2007.

J. Radinsky, B. Loh, J. Lukasik, GIS tools for historical inquiry: Issues for classroom-centered design, "Journal of the Association of History and Computing”, 11 (2), 2008.

S. Salvatici (ed.), Confini. Costruzioni, attraversamenti, rappresentazioni, Soveria Mannelli, Rubbettino, 2005.

E. Squarcina, Didattica critica della geografia. Libri di testo, mappe, discorso geopolitico, Milano, Unicopli, 2009.

James W., Wilson, GIS and historical scholarship: A question of scale, "International Journal of Humanities \& Arts Computing", 3 (1-2) 2009. 
Ebubekir Ceylan

Fatih University

\title{
An Analysis of History of Turkish Education: Sources, Pioneers and Approaches
}

\begin{abstract}
This paper aims to present an overview of the history of Turkish education. For this purpose, the relationship between Ottoman modernization and the reforms in the field of education is underlined. In terms of the period under study, the paper covers the period from late Ottoman history and to the Republican Era. The first part of the paper concentrates on the educational institutions, ranging from traditional schools (such as sibyan mektebi and madrasa), to modern secular schools in Turkey. Then, the sources of Turkish education are analyzed. The importance and the use of the primary sources such as the Ottoman Prime Ministry Archive, vakfiye registers, and state yearbooks are emphasized in this section. Leading secondary sources are also stressed. In its third section the paper dwells upon an important methodological debate in Turkish education: whether to build and reform the education from top down or bottom up. Here, Emrullah Efendi's the Tuba tree theory is summarized and proponents and opponents of these approaches are briefly mentioned. The final section is on the history textbooks in Turkey. The paper draws attention to the political agendas of the ruling elites and their influence on the history textbooks. The paper highlights the continuity in education institutions and manpower from late Ottoman to the Republican history.
\end{abstract}

\section{Introduction - Ottoman Modernization and Education}

The political developments in the late Ottoman Empire, as it is the case in any modernizing society, were very much related to the developments in Ottoman-Turkish education. The nineteenth century, known as the longest 
century of the Ottoman Empire, was a period of reform, modernization and centralization; and education, though relatively late, was also touched by these reform initiatives. The modernization process in Turkey included state centralization and the weakening of the traditional sources of authority. In this process the authority of the state spread from center to periphery. Education was one of the field by which the central state began to penetrate and shape the periphery. While in the classical period expenditures of education were not met by the government, starting from the mid-nineteenth century public education became one of the main tasks of central administration. ${ }^{1}$

The first civil and secular government schools were opened with the purpose of bringing up a body of civil servants required for the newly growing bureaucracy. In this regard it would not be wrong to say that the modernization of Ottoman bureaucracy is closely intertwined with history of education in Turkey. The developments and reforms in the field of education during the late Ottoman period were important in the sense that the legacy of educational uniformity and centralism was subsequently adopted by the Turkish Republic.

While the first serious attempts for modernization were laid down in the imperial Edict of Gülhane in 1839, the field of education had been hardly touched in this document. During the whole Tanzimat period (1839-1876) we see an increasing emphasis on Ottomanism. Due to the nationalist uprising in the Balkan provinces of the Ottoman Empire, the ruling elite launched a policy of Ottomanism for preventing separatist nationalist movements. The policy of Ottomanism, which became the official ideology of the Ottoman state during the Tanzimat period, aimed to embrace all of the Ottoman subjects regardless of their ethnicity, religion and language. This policy had very significant role in terms of the transformation of Ottoman "subjects" into "citizens". The Ottoman case in this sense bears significant resemblance with the contemporary states. ${ }^{2}$

As the result of this, the Ottoman government made the legal arrangements and promulgated the law for citizenship in 1869. The idea was to create an "Ottoman nation" and "good citizens" and, as will be seen in the following parts, these developments had significant reflections on the

1 M. Alkan, Osmanlı Imparatorluğunda Modernleşme ve Eğitim, in Türkiye Araştırmaları Literatür Dergisi, Vol 6, No 12, 2008, p. 11.

2 B. Fortna, Mekteb-i Hümayun. Osmanlı Imparatorluğu'nun Son Döneminde İslam, Devlet ve Eğitim, İstanbul, İletişim Yayınları, 2005, pp. 67-73. 
textbooks in the schools. As will be detailed below, the second half of the $19^{\text {th }}$ century witnessed significant reforms in the field of education. It is an undeniable fact that the founding cadre of the Republican Period was educated in these modern and secular schools.

The reign of Abdülhamid II (1876-1909), was a period in which education began to spread from imperial center to the provincial periphery. In terms of the number of schools opened, this period represents the peak point of the $19^{\text {th }}$ century Ottoman history of education. In addition to the proliferation of the secondary schools, Abdülhamid II opened many Occupational High Schools as well.

As Somel pointed out, Ottoman educational reforms contained to a considerable degree the ancient tradition of viewing education as a means of inculcating religious and moral values to students with the ultimate aim to ensure feelings of obedience and loyalty toward the central authority. ${ }^{3}$ This understanding of education was more dominant during the last decades of $19^{\text {th }}$ century Ottoman world. Abdulhamid II is believed to have ignored the traditional Quran schools (madrasas) and made the modern schools widespread throughout the empire. When compared with the traditional schools, the modern schools had less courses on religion and moral values. Instead a positivist and materialist thought came to spread in these schools. It is quite interesting that the graduates of these modern and secular schools produced an elite group that opposed the very political regime of the sultan. It is for this reason that the curriculums were rearranged and courses on religious and moral values were increased. This was more strictly applied in schools that brought up bureaucrats of the later years. ${ }^{4}$ Furthermore, although the modernization attempts of Tanzimat period were maintained during the reign of Abdülhamid II, the stress on westernization was now reversed and the emphasis on "Ottomanism" left its place to "Islamism".

In the atmosphere of the Balkan Wars and the World War I, the Young Turks began to see the solution in the promotion of Turkish nationalism as opposed to the Ottomanism and Pan-Islamism of the previous decades. There is no doubt that the WW I affected education negatively, as many students and teachers had to fight in the frontiers rather than studying in classes.

3 S. A. Somel, Modernization of Public Education in the Ottoman Empire, Leiden, Brill, 2001, p. 6.

4 M. Alkan, Osmanlı İmparatorluğunda Modernleşme ve Eğitim, cit., p. 16. 
While the late Ottoman and the Young Turk Era prepared the background for a true reform in the field of education, the first decade of the Republican Period created the suitable conjuncture for the realization of these reforms. In the first five years the emphasis of the Kemalist regime in Turkey was on the Unification of Education and Alphabet reform. ${ }^{5}$ With the Law of Unification of Education in 1924 the Kemalist aimed to abolish the existing dualism in education and for this purpose they outlawed the traditional schools, namely madrasas. On the other hand, with the adoption of Latin alphabet the Republican regime turned its face to the West. It was for this reason that the 1930s and 1940s was a period in which the Kemalists aimed to increase the literacy level and spread public education. People's Houses and Village institutes were quite significant instruments not only in trying to increase the level of literacy but also in terms of the indoctrination of the Kemalist regime to the populace.

The emphasis during the Republican period was on Turkish nationalism based on Turkish race and culture. This is quite evident in the formation Turkish Historical Thesis and Sun-Language Theory in early 1930s. However, it is also an undeniable fact that Kemalists during the Republican period strived much for the development of a national education policy. The equality in education, emphasis on girls, and teachers as the pioneers of change and development were the leading emphasis of the Republican regime.

\section{Educational Institutions in Ottoman Turkey}

Until the eighteenth century education in the Ottoman Empire consisted primarily by traditional religious schools ${ }^{6}$. While the Quran schools, known as sibyan schools, were for the elementary level education, the madrasas served for the purpose of higher level education. Both of these

5 N. Sakaoğlu, Cumhuriyet Döenmi Eğitim Tarihi, İstanbul, İletişim Yayınları, (2nd ed.), 1993, p. 29; Y. Akyüz, Türk Eğitim Tarihi: M.Ö. 1000-M.S. 2008, İstanbul, Pegem Akademi, 2008.

6 The Court School at the Topkapı Palace (Enderun Mektebi), and School of the Janissary novices (Acemi Oğlanları Mektebi) were exceptions. These schools had distinct features and was closed to Muslim subjects of the empire. 
institutions were civil educational for Muslim population of Ottoman Empire and they were under the control of the lower ulema (Ottoman learned class). The Quran schools were the step where the pupils began their early education. Therefore, it would not be wrong to say that they were the first level of public education.

Despite the introduction of some modern schools (especially in the military field) these traditional schools constituted the skeleton of the educational institutions. However, it was during the 19th century that thanks to the modernizing reforms these traditional Ottoman institutions lost their importance and secular government schools came to the forefront. As the Ottoman attempts for modernization started first in the military institutions, so was the case in the field of education. Military Engineering schools (Mühendishane-i Berri Hümayun and Mühendishane-i Bahri Hümayun), Military Academy of Medicine and Military Academy of War were the first examples of modern schools in the late eighteenth century Ottoman Empire. Later on civil educational institution were gradually established, the purpose of which were to meet the need for qualified persons in the state bureaucracy.

The reign of Mahmud II (1808-1839) witnessed the early attempts for modernization in education. He selected a few strudents and sent them to Europe for education in military sciences. It was again during his reign that primary public (religious) education became obligatory in $1240 \mathrm{AH} /$ AD 1824-18257. The imperial decree was strengthened with an Islamic discourse and made the school teachers, local judge ( $k a d l)$, local Muslim leader and preacher (imam) and the head of the guilds responsible for the implementation of the new regulation. The importance of the ferman laid in the fact that the need for education and significant of being literate were articulated for the first time by an Ottoman sultan. ${ }^{8}$ Despite this first sultanic initiative, one has to wait until the late 1830 s and early 1840 s for the establishment of first civil schools. While the traditional schools were usually built next to the mosques, this was no longer a concern for the secular governmental schools.

7 The text of the imperial decree (ferman) can be seen in Mahmud Cevad İbnü'ş Şeyh Nafi, Maarif-i Umumiye Nezareti: Tarihçe-i Teşkilat ve Ícraatı - 19. Yüzyıl Osmanlı Maarif Tarihi (compiled by Taceddin Kayaoğlu), Ankara, Yeni Yürkiye Yayınları, 2001, pp. 3-5.

8 N. Sakaoğlu, Osmanlıdan Günümüze Eğitim Tarihi, İstanbul, Bilgi Üniversitesi Yayınlar1, 2003, p. 59. 
The ibtidâiyye (primary) schools accepted children no less than 6 years old. Therefore, it would not be wrong to say that the ibtidâiyye schools were modern versions of the traditional Quran schools. After a 4-year study in the ibtidâiyya school, the student could go to the rüsdiye schools. The rüşdiye schools admitted only the graduates of ibtidâiyye schools and during its 3-year study, the students were taught the following courses: Mathematics, Engineering, Accounting (Hisâb), Geography, History, Basic Health Information, Illm-i hâl, language, and Calligraphy. The traditional schools did not have a system of classroom; it was only with the rüssdiye schools that class system was introduced. It was quite probable that the quality of education and the diversity of courses changed from region to region.

The reign of Mahmud II witnessed the insufficiency of the sibyan schools and a reform program for these schools was planned. However, later a new school, named rüssdiye mektebi, was introduced. The pupils could visit the rüşdiye schools after their graduation from the sibyan/ ibtidaiye schools. A new ministry for rüşdiye schools (Mekatib-i Rüşdiye Nezareti) was created. Though some researchers consider the Mekteb-i Maarif-i Adliye as the first rüsdiye school in 1838, some other stressed the occupational character of this school..$^{9}$ It is for this reason that the first rüssdiye school is believed to be opened in İstanbul in 1847 . When the first rüşdiye became successful, new rüşdiye school began to be opened, but its dissemination to provincial periphery required several decades. As far as the curriculum of these schools were considered, at the beginning the reading of the Quran, Writing, and basic computation and Arabic come to the forefront, but later Geography, Mathematics and Persian were added to the curriculum.

The ministry that was earlier established with regard to the rüşdiye schools was, in 1846, extended to cover other public schools as well: Ministry for Public Schools (Mekatib-i Umumiye Nezareti). Until 1867 the rüşdiye schools accepted only Muslim students, but parallel to the Ottomanist policy of the period, non-Muslims pupils began to be accepted after this date. The regulation for rüşdiye schools, which was issued in 1869, further improved the conditions and service of these schools ${ }^{10}$.

9 K. Bayram, Abdülhamid Devri Eğitim Sistemi, Ankara, Türk Tarih Kurumu, (3rd. ed.), 1999, pp. 91-92.

10 For the articles of this regulations see, ibid, p. 93. 
How successful were the rüşdiye schools? Somel answers this question as follows: "Looking at the Tanzimat period prior to 1869 , the main steps of reform in the realm of education could be observed in the fields of secondary and professional institutions. Though rüşdiyye schools as institutions embodied educational modernization during this period, they ultimately proved to be unsuccessful as secondary schools. ${ }^{11}$ Despite the introduction of civil educational institutions, traditional schools continued to exist, and as in many other Tanzimat institutions, institutional dualism continued in the field of education.

The basic characteristic of the Tanzimat period in terms of history of Ottoman-Turkish education is the growing state control over the educational institutions and the concomitant decline of the ulema's role in these institutions. The decreasing control of the ulema on the educational institutions and the growing number of governmental schools meant a significant degree of secularization in the field of education. One concrete example of this process was the change in the terminology. For instance, as far as teachers are concerned, muallim/muallime replaced the traditional "hoca". ${ }^{12}$

The most significant turning point of the mid-nineteenth century is the foundation of Ministry of Public Education in 1857. The growing need for public education was the primary reason for its establishment. With the promulgation of Regulation of Public Education (Maarif-i Umumiye Nizamnamesi) in 1869 the Ottoman Empire assumed the responsibility to provide modern education for its subjects. ${ }^{13}$ The Regulation, which was adopted under the influence of French Ministry of Education, is considered to be the sign of an important shift toward a more secular understanding of primary education. The Sublime Porte had now more saying over the schools and the school buildings began to be constructed in accordance with the plans sent from İstanbul. The regulation also envisioned the establishment of education councils in the provincial capitals. It is quite meaningful that by 1872 only two provinces had education councils, namely Tuna and Baghdad, where Midhat Pasha had provided the necessary infrastructure.

11 S. A. Somel, Modernization of Public Education in the Ottoman Empire, cit., p. 8.

12 M. Alkan, Osmanl Imparatorluğunda Eğitim ve Ĕgitim İstatistikleri, 1839-1924, in Halil İnalcık and Şevket Pamuk (eds.) Osmanlı Devleti'nde Bilgi ve İstatistik, Ankara: T.C. Başbakanlık Devlet İstatistik Enstitüsü Yayınları, 2000, p. 15.

13 Ivi, p. 127. 
The 1870s and the Hamidian period, in general, witnessed the rise of primary ibtidâi schools and the secondary idâdî schools, while the rüssdiyyes of the Tanzimat period, though continuing to exist, increasingly became obsolete". ${ }^{14}$ The traditional sibyan schools were reorganized and became ibtidaiye (primary) schools; however, this period comes to the forefront with a strong emphasis on idadi (secondary) schools. This period also witness the foundation of mekteb-i sultanis, namely the and Darüşşafaka Lisesi.

\section{Sources}

Among the sources of the history of education in Turkey, the archives, vaklf registers, court registers and yearbooks come to the forefront. The Ottoman archives contains thousand (perhaps millions) of documents on Turkish education. The researchers can search on the website of Prime Ministry Ottoman Archives. Some of the files in the archives are quite more related to the educational institutions. For instance the catalogue of Ruus Defters contains 261 defters referring to the developments in the last two centuries of Turkey. Among other things, the Ruus Defters include Medaris-i Edirne ve Bursa (two defters), Medrese, Müderrislik, Müderrislik-i İstanbul, Müderrislik-i Edirne, Müderrislik-i Bursa, Medaris-i Edirne Ruusu, and Medaris-i Asitane-i Aliyye. ${ }^{15}$ These registers are quite crucial for the traditional schools in Istanbul as well as neighboring cities of Bursa and Edirne.

The vakfiyes (foundation certificates) are also significant sources of history of education in Turkey. Vakfiye is the register of a foundation (vakuf), which resembles to present-day NGOs. In the Ottoman Empire, the construction of public works, including the educational institutions, were mainly conducted by these foundations. Though a considerable number of these foundations were established by the member of the Ottoman dynasty and the leading bureaucrats, these foundations were distinct from state bureaucracy and played very important role in the spread of

14 S. A. Somel, Modernization of Public Education in the Ottoman Empire, p. 8.

15 M. Hızlı, O. Eğitim Tarihinin Arşiv ve Y. Kaynakları, Türkiye Araştırmaları Literatür Dergisi, Vol. 6, No. 12, 2008, pp. 577-592. 
educational institutions. Each foundation has a register, known as vakfye. These registers were prepared by the founder of the foundation and ratified by the local court. They include information concerning the functioning of the foundation, its revenues and expenditures, and the management of the foundation. Most of the traditional schools in the Ottoman Empire were built by foundations. Therefore, they have usually a register document (vakfiye). The register of a traditional school usually contain information about the number of students, the scholarship to be given to the students, the accommodation of the students, the number of teachers and their salaries, the courses to be taught to the students etc. In short, these data are quite crucial for the understanding of traditional educational institution. The registers of the foundations can be found in the archive of the Vakiflar Genel Müdürlüğü Arşivi (General Directorate of Foundation) however, unfortunately, not all of these registers reached our present day. As these documents were also registered in the local court, they could also be found in the court registers (ser'iyye sicilleri). Hence, the court registers are also one of the sources of history of education.

Another significant source for the history of Ottoman-Turkish history is the yearbooks known as salnames. Salnames began to be published in the Ottoman Empire after 1847 and between 1847 and 1911, 68 volume state yearbooks (devlet salnameleri) were published ${ }^{16}$. While the earliest yearbooks were approximately around 100 pages, gradually their volume increased and reached more than 1000 pages. The state yearbooks contain data concerning not only administrative, military organization of the empire, but also cultural and historical issues as well. Apart from state yearbooks, there were provincial yearbooks, which are more important for the local history of a particular region. The provincial yearbooks were usually published in the provincial print house. These provincial yearbooks contain data pertaining agriculture, natural sources, animal husbandry, local population, hospitals, schools, administrative and military officials and so on. The first provincial yearbook was published in 1866 in Bosnia. Until the end of the Ottoman Empire more than 500 provincial yearbooks were printed.

In the course of time, some of the state department began to publish their own yearbooks. These institutional yearbooks were in a true sense the inventory of a particular state department. The most well known of

16 For detailed information on yearbooks in the Ottoman Empire see H. Duman, Osmanl Salnameleri ve Nev-salleri Bibliyografyası ve Toplu Kataloğu, Ankara, 1999. 
these institutional yearbooks have been yearbook of Foreign Affairs ( $h a-$ riciye salnamesi), yearbook for Learned Classes (ilmiye salnamaesi) and yearbook of Ministry of Public Education. The purpose of the institutional yearbooks was to list the institutions and the name of the official tied to a particular ministry.

As far as yearbooks of education (maarif salnamesi) are concerned, one should note that these yearbooks have been one of the most significant sources for the history of Ottoman-Turkish history of education. Between 1898 and 1903, six yearbooks were published. There were entitled Salname-i Nezaret-i Maarif-i Umumiye (Yearbook of Ministry of Public Education). These yearbooks contain detailed information on the history of Ministry of Public Education, ministers of education, the officials, teachers, schools, libraries, exams, awards, educational institutions in the provinces, and the ratio of the pupils with regard to the provincial population and so on (Hizl1, 2008). In the History on Line portal, we uploaded one of these yearbooks of Ministry of Public Education. It was published in $1317 \mathrm{AH}$ (1899). That it is 1512 pages, gives the detailed information in contains. Through this yearbook of Ministry of Public Education (maarif salnamesi) one can read the biographies of ministers of education, the regulations concerning education, curriculums and the contents of the courses. For example, one can also learn the number of schools in Erzurum, the date of their constructions, officials in directorate of education in Erzurum, and the number of students among other topics.

As far as secondary sources are concerned, several works come to the forefront. Mahmud Cevad's Tarihçe-i Nezaret-i Maarif-i Umumiye, Nafi Atuf Kansu's Türkiye Eğitim Tarihi Hakkında Bir Deneme, and Osman Ergin's five-volume Türkiye Maarif Tarihi are worth to mention here.

Mahmud Cevad is usually considered to be the first historian of education in Turkey. After the 1908 revolution, he began to serve in the Ministry of Public Education. For his Tarihçe-i Nezareti Maarif-i Umumiye he extensively made use of the archives of the ministry. Although the book was first planned as a two-volume work, due to the difficulties encountered during the WWI it was published in 1920 as a single volume. The book starts with the sultanic ferman that made primary education compulsory. The book narrated the developments concerning history of education in chronological order, especially in accordance with the ministers in charge. The opening of various schools, developments concerning the ministry 
itself, educational journals, libraries are among the topics discussed by the author. ${ }^{17}$

Nafi Atuf Kansu was one of the leading intellectuals who contributed to Turkish education during the Republican period. Fenn-i Terbiye Tarihi (1916), Pedagoji Tarihi (1929), Türklerin Terbiyeye Hizmetleri (1934) and Türkiye Maarif Tarihi Hakkında Bir Deneme (2 vols. 1931-1932) are among his major works. His two-volume Türkiye Maarif Tarihi Hakkında Bir Deneme is available on History on Line portal. His work starts with the classical educational institutions (madrasas, sibyan mektebi, Enderun, and first modern engineering schools) in the Ottoman Empire until the Tanzimat Period (1839). Kansu, among other things, dwells on the conditions of the schools in Turkey. He especially describes the miserable conditions of educational institutions and incompetent teachers: the sanitary conditions were not sufficient, the teachers were usually very old, and the one-room class was not adequate for the students. For the Tanzimat period, the author put emphasis on modern secular schools, such as rüşdiye, sultani, darulmuallimin, darulfünun and non-Muslim schools. In the second volume, the state of education during the Second Constitutional Period, agricultural education, girl's education, the theory "Tuba tree", national education and Ziya Gökalp are among the topics discussed by the author. This two volume work, however, have been criticized for his relatively official discourse, insufficient number of documentation and lack of analytical interpretation with regard to the political conjuncture of the period. With the publication of Osman Ergin's Türkiye Maarif Tarihi, Kansu's work began to loose its importance in the field.

Osman Nuri Ergin's five-volume Türkiye Maarif Tarihi is one of the most important and encompassing works on history of Turkish education. Educated in the late Ottoman institutions and survived the Republican period, Osman Nuri Ergin produced many work on Turkish education. By his multi-volume work Ergin aimed to surpass 3 books: Nafi Atuf Kansu's Türkiye Eğitim Tarihi Hakkında Bir Deneme, Mahmud Cevad's Tarihçe-i Nezaret-i Maarif-i Umumiye and Hasan Ali Yücel's Türkiye'de Orta Öğretim..$^{18}$ When compared to Kansu's book, Türkiye Maarif Tarihi has enormously rich primary sources. The rich archival documents, manuscripts,

17 M. Selçuk, 'M. Umumiye Nezareti Tarihçe-i Teşkilat ve İ. Üzerine Bir Değerlendirme, Türkiye Araştırmaları Literatür Dergisi, Vol. 6, No: 12, 2008, pp. 729-731.

18 A. A. Yörük, E. T. Kırkanbar Müellifi, Osman Nuri Ergin, Türkiye Araştırmaları Literatür Dergisi, Vol. 6, No: 12, 2008, pp. 689-693. 
secondary sources, periodicals and oral sources are almost impossible for a contemporary researcher to exploit. Today, this multi-volume is probably the first source for a student to enter into the world of history of Turkish education.

\section{Pioneers and Approaches to Turkish Education}

The first decades of the twentieth century witnessed quite significant discussions of various approaches concerning Turkish education. Emrullah Efendi had a leading role in these discussions. Emrullah Efendi was born in 1858 and he served in different positions: he was appointed as the member of the education council, and became director of mekteb-i sultani. After the 1908 election he entered to the National Assembly as MP of Kurklareli. He served twice as the minister of Public Education, first in January 1910 and then in December 1911. ${ }^{19}$ Emrullah Efendi wrote many articles in newspapers and journals. He is the author of encyclopeadic Muhitu'l-Maarif.

Emrullah Efendi is well-known for his educational approach, formulized as "the theory of Tuba Tree". This approach of Emrullah Efendi emphasized the structuring of the educational system from top down. In fact, the political conjuncture was quite effective in Emrullah Efendi's view. As mentioned at the beginning of this article, due to the westernization and modernization attempts, the Ottoman Empire felt it necessary to start from and give priority to the secondary and high educational institutions. The lack of qualified officials and bureaucrats was an important reason for this top down approach in education. ${ }^{20}$ Rather than putting emphasis on primary schools, higher educational institutions were emphasized for the sake of bringing of qualified officials. Emrullah Efendi believed that although the organization of the educational institutions is from primary to secondary and high schools, the science and knowledge is transmitted from top to bottom. ${ }^{21}$

19 M. Ergün, E. Efendi, H.-G. Çalışmaları, Ankara Üniversitesi Dil ve Tarih-Coğrafya Fakültesi Dergisi, Vol. 30, No: 1-2, 1982, p. 8.

20 Ibid.

21 E. Emrullah, T. A. Nazariyesi, Yeni Mecmua, 9 August 1333 AH, 1914. 
The metaphor of Tuba tree comes from the fact that the Tuba tree is believed to be a tree in the Paradise. The distinctive characteristic of this tree is that its roots are said to be not in the soil, but in the air. That is to say, the tree is fed not from the bottom, but from the air. This metaphor, according to Emrullah Efendi, underlines the significance and the priority of higher educational institutions. It is for this reason that this approach has also brought the issue of "elite education" into agenda. During his service in the ministry, he upgraded the idadi schools to level of mekteb-i sultani and increased the number of faculties in the university (Darülfünun) in Istanbul from three to five. Therefore, Emrullah Efendi is believed to have developed the idea of modern university. ${ }^{22}$ Emrullah Efendi argued that:

The science starts from above. When I put forward this theory, I did not say that I will not build primary schools or I will not give significance to them. I will surely pay attention to them. I will start from above for the sake of these primary schools. The genealogy (three) of education is for sure like the Tuba tree. Its roots are up. ${ }^{23}$

By saying this, Emrullah Efendi implied that the reform and improvement of higher educational institutions is crucial for bringing up good students in primary schools. Therefore the reform of the secondary and high school was to serve to the primary schools at the end.

The theory of Tuba tree was discussed widely not only during the lifetime of Emrullah Efendi, but the debates intensified after his death. There were both proponents and opponents of Emrullah Efendi's theory. M. Sati Husri, for instance, was probably the most prominent figure who opposed the theory of Tuba tree. M. Satı known also as Satı El-Husri, is one of most significant figures of Turkish education at the very beginning of the 20th century. Born in 1880 in Yemen, M. Satı graduated from administrative school (Mülkiye Mektebi) in 1900 and served as teacher for some years. Due to his journal articles and close interests in education, he was appointed as director of School for Teachers (Darülmuallimin) in 1909. His opposition to the theory "Tuba tree" of Emrullah Efendi (who was then the Minister of Public Education) was quite effective in his resignation from this directorate. M. Sat1 published more than 15 books and wrote many articles on education in various journals. His Fenn-i Terbiye is available in digital format at History on Line portal.

22 N. Sakaoğlu, Osmanlıdan Günümüze Eğitim Tarihi, cit., p. 308.

23 M. Ergün, E. Efendi, H.-G. Çalışmaları, Ankara Üniversitesi Dil ve Tarih-Coğrafya Fakültesi Dergisi, cit., p. 14. 
Unlike Emrullah Efendi and his theory of Tuba tree, M. Satı argued that education should be structured from the bottom. However, most of his writings on this subject appeared after the death of Emrullah effendi. According to M. Sat1, education starts from the very ground. The institutions of higher education can not be built upon a weak and corrupt primary education. A genuine class of intelligentsia grows up not like the Tuba tree, but normal trees. ${ }^{24} \mathrm{M}$. Sat1 stressed the strong link and hierarchy between the levels of educational institutions. In this context, the development of high school is bound to development of primary and secondary schools. In response to Emrullah Efendi's arguments M. Satı asserted that in Balkan countries and Japan the higher educational institutions (universities) were established after that the consolidation of the primary schools. ${ }^{25}$

The discussion on methodology in education was not only between Emrullah Efendi and M. Satı Husri, rather it was maintained by the representatives of both sides in later decades. Feridun Vecdi and Ziya Gökalp were among the well-known followers of Emrullah Efendi's theory.

\section{School Textbooks and Politics}

While in the classical period, history education was limited to members of the ruling elite, especially those in the Ottoman palace, during the $19^{\text {th }}$ century it came to be an important instrument for bringing up statesmen as well as learned classes. This is to some extend related to the emergence of history as an academic discipline in the $19^{\text {th }}$ century.

Besides the institutions of bureaucracy and military, education has been one of the most significant institutions by which the official state ideology is conveyed to mass population and their obedience and loyalty is assured. It is for this reason that one of the essential functions of education, not only in the Ottoman Empire, but also in other countries as well, has been the functioning of "social disciplining". ${ }^{26}$ As it is detailed below, this social disciplining easily shifted into "social engineering".

24 M. Sat1, T. A. Nazariyesi, Muallim Dergisi, I/12, 1914.

25 M. Ergün, S. Bey, H. ve Türk Eğitimine Hizmetleri, İnönü Üniversitesi Sosyal Bilimler Dergisi, Vol. 1, 1987, p. 5.

26 S. A. Somel, Modernization of Public Education in the Ottoman Empire, cit., p. 5. 
However, it is also a well known fact that the modern history has many examples of governments that tried to convey their values and ideologies to the society through educational means. They considered the educational institutions not only as places for obtaining knowledge, skills and talents, but also as places where the pupils could be indoctrinated with the state ideology or weltanschaung. In this context, the school textbooks and the curriculums are quite useful in tracing the reflections of state ideology. In a similar fashion, the textbooks in Late Ottoman Empire played crucial role in conveying the Ottomanism of Tanzimat period, the Islamism of Hamidian regime and the Nationalism of the Young Turk Era.

It was during the Tanzimat period (1839-1876) that patriotism and citizenship came to the forefront in education. In accordance with the Ottomanism policy, congregational structures (millets) were allowed certain freedom with regard to primary education. The policy of Ottomanism was more visible in the sultani schools in which Muslim and non-Muslims were educated together.

In parallel with the westernization/modernization process of the Tanzimat period, textbooks were translated in to Ottoman Turkish under the institutional guidance of Encümen-i Daniş, established in $1851 .{ }^{27}$ The result was that when compared with the courses on religion, the science courses dominated the curriculums. Courses on moral values and religion were almost not taught after the rüşdiye schools. History textbooks regarded the Tanzimat modernization/westernization as an achievement in Ottoman history.

As Somel pointed out, the Hamidian period (1876-1908) prohibited any school instruction independent of the repetition of the textual content of those schoolbooks approved by the Ministry of Public Education. Thus the usage of textbooks with the desired educational content became a standardized procedure in the late Ottoman Empire. ${ }^{28}$ The yearbook of education contains a section which indicates the time schedule of each topic to be taught in the schools. Which subject should be taught at which longevity? Which class is proper for the teaching of a particular topic? Similar questions were answered in the yearbook of education.

It is quite interesting that Abdülhamid II, who is well-known for the proliferation of modern schools in late Ottoman history, had in the course of time changed the curriculum of the schools, because he realized that

27 M. Alkan, Osmanlı Imparatorluğunda Modernleşme ve Eğitim, cit., p. 28.

28 S. A. Somel, Modernization of Public Education in the Ottoman Empire, cit., p. 7. 
the same modern schools gave way to the emergence of Young Turk movement, the first organized political opposition to the Hamidian regime. Therefore, starting from early $1890 \mathrm{~s}$, he ordered for an increase in the hours of courses on religion and morality hoping that this will strengthen the sense of loyal among the students. The students were expected to observe religious precepts at school, and textbooks on humanities were reshaped toward this direction. ${ }^{29}$

Mehmet Alkan argued that the textbooks in military and civil schools differed from each other in that the former ones included detailed sections on early Turkic mythologies (and hence on Turkish identity) which might account for the development of Turkish nationalism among the army officers. ${ }^{30}$ Abdülhamid II's emphasis on "Islamic-Turk Synthesis" turned into "Turco-Islamic Synthesis" and Turkish nationalism during the Second Constitutional Period.

Perhaps the most striking example for the use of history textbooks as tools of political and cultural indoctrination took place in early 1930s. As far as the history textbooks in 1930s are concerned several of them come to the forefront. The first work which worth to mention was Türkiye Tarihi (History of Turkey) which was written by Hamit and Muhsin in 1930. Used as a textbook in secondary schools, the authors made emphasis on the historical events rather than the great persons in history. ${ }^{31}$ Unlike the other history textbooks written in 1930s, this book allocated great room for Ottoman history. Nevertheless, the use of primary sources is almost absent.

The history textbooks written in 1930s give us important clues with regard to the use of history textbooks by the political authorities. Mustafa Kemal Atatürk commissioned a group of scholars to write Türk Tarihinin Anahatlart in 1929. Under the pressure of Mustafa Kemal, the authors, most of which were parliamenters of the ruling party (Republican People's Party), compiled the book in a very short period of time. Therefore, the book was criticized not only for its mistakes, but also lack primary source as well. ${ }^{32}$ The book put emphasis on history of Turkish people in the pre-Islamic period, while the glorious Ottoman history was shortly

29 Ivi, p. 4.

30 M. Alkan, Osmanlı Imparatorluğunda Modernleşme ve Eğitim, cit., p. 34.

31 B. Ersanl, İktidar ve Tarih, İstanbul, İletişim Yayınları, 2003, p. 116.

32 İ. H. Uzunçarşılı, T. T. Yazılırker, Belleten, Vol. 3/3, 1939, 1939, p. 349. 
summarized. The authors made use of the works of prominent Turcologists, but Ottoman/Turkish primary sources were not used at all. ${ }^{33}$

The purpose of book the book was quite clear: to glorify the honor of the Turks. Parallel to this purpose, it was underlined that the Turks has an inherent (racial) ability in state organization. the introductory 90 pages (known as Türk Tarihinin Anahatlart-Medhal Kısmı), of the 605 page long book was reprinted in 1931 and used as a supplementary book in the schools.

Türk Tarihinin Anahatları became source of inspiration for other history textbooks. Ortamektep Için Tarih III (History for Secondary Schools III) was first published in 1933 and this three-volume book soon became a standard history textbook in the secondary schools. Inspired by Türk Tarihinin Anahatlarl, this book exalted the Turkish race and asserted that the Turks not only established great civilizations but also affected other ancient civilizations. There is no doubt that these history textbooks prepared the necessary background for the formulation of Turkish Historical Thesis and the Sun-Language Theory in early 1930s.

\section{Concluding Remarks}

For the last two centuries Turkey has been in the process of modernization and the educational institutions were indispensible instruments of this process. In a nutshell, it should be underlined that the bureaucrats and intellectuals who graduated from the modern and secular schools played quite significant role in Ottoman/Turkish modernization. In this regard, thanks to the modern educational institutions which were established during the late Ottoman history, their graduates actively shaped the Republican period and implemented many reforms as in the field of education. It would not be wrong to state that the Ottoman legacy in educational institutions and the Ottoman manpower made it possible for young rulers of Turkey in the first quarter of the $20^{\text {th }}$ century to built upon/reform the Turkish education.

33 B. Ersanl, Iktidar ve Tarih, cit., p. 121. 


\section{Bibliography}

Yahya Akyüz, Türk Eğitim Tarihi: M.Ö. 1000-M.S. 2008, İstanbul, Pegem Akademi, 2008.

Mehmet Alkan, Osmanlı Imparatorluğunda Eğitim ve Ĕ̈itim İstatistikleri, 1839-1924, in Halil İnalckk and Şevket Pamuk (eds.) Osmanlı Devleti'nde Bilgi ve İstatistik, Ankara: T.C. Başbakanlık Devlet İstatistik Enstitüsü Yayınları, 2000.

Mehmet Alkan, Osmanlı Imparatorluğunda Modernleşme ve Ĕgitim, in Türkiye Araştırmaları Literatür Dergisi, Vol 6, No 12, 2008.

Hasan Duman, Osmanlı Salnameleri ve Nev-salleri Bibliyografyast ve Toplu Kataloğu, Ankara, 1999.

Efendi Emrullah, Tuba Ağacı Nazariyesi, Yeni Местиа, 9 August 1333 $\mathrm{AH}, 1914$.

Mustafa Ergün, Emrullah Efendi, Hayatı- Görüşleri- Çalışmaları, Ankara Üniversitesi Dil ve Tarih-Coğrafya Fakültesi Dergisi, Vol. 30, No: 1-2, 1982.

Mustafa Ergün, Satı Bey: Hayatı ve Türk Eğitimine Hizmetleri, İnönü Üniversitesi Sosyal Bilimler Dergisi, Vol. 1, 1987.

Büşra Ersanlı, İktidar ve Tarih, İstanbul, İletişim Yayınları, 2003.

Benjamin Fortna, Mekteb-i Hümayun. Osmanlı Imparatorluğu'nun Son Döneminde İslam, Devlet ve Ĕgitim, İstanbul, İletişim Yayınları, 2005. Muhsin Hesapçığlu, Alpaslan Durmuş (eds.), Türkiyede Eğitim Bilimleri: Bir Bilanço Denemesi, Ankara, Nobel Yayın Dağıtım, 2006.

Mefail Hızlı, Osmanlı Eğitim Tarihinin Arşiv ve Yazma Kaynakları, Türkiye Araştırmaları Literatür Dergisi, Vol. 6, No. 12, 2008.

Kodaman Bayram, Abdülhamid Devri Eğitim Sistemi, Ankara, Türk Tarih Kurumu, (3rd. ed.), 1999.

Sakaoğlu Necdet, Cumhuriyet Döenmi Eğitim Tarihi, İstanbul, İletişim Yayınlar1, (2nd ed.), 1993.

Necdet Sakaoğlu, Osmanlıdan Günümüze Eğitim Tarihi, İstanbul, Bilgi Üniversitesi Yayınları, 2003.

M. Satı, Tuba Ağacı Nazariyesi, Muallim Dergisi, I/12, 1914.

Mustafa Selçuk, 'Maarif-i Umumiye Nezareti Tarihçe-i Teşkilat ve İcraatı' Üzerine Bir Değerlendirme, Türkiye Araştırmaları Literatür Dergisi, Vol. 6, No: 12, 2008. 
Selçuk Akşin Somel, Modernization of Public Education in the Ottoman Empire, Leiden, Brill, 2001.

İsmail Hakkı Uzunçarşılı, Türk Tarihi Yazılırker, Belleten, Vol. 3/3, 1939, 1939.

Ali Adem Yörük, Eğitim Tarihimizin Kırkanbar Müellifi, Osman Nuri Ergin, Türkiye Araştırmaları Literatür Dergisi, Vol. 6, No: 12, 2008. 

ROBERTO SANI

JURI MEDA

ANNA AsCENZI

Marta BRUNELLI

University of Macerata

\title{
Publishing for the School and Textbooks in the Fascist Twenty-Year Period. From the Gentile Reform to the End of the WWII (1923-1945)
}

\begin{abstract}
The essay retraces the main phases of the history of textbooks from the Gentile Reform to the end of the Second World War. After a short introduction of historiographical nature, the essay examines in depth the school legislation on textbooks, which was elaborated during the fascist twenty-year period, with a special focus on the situation of the primary school. An analysis follows of the panorama of the publishing for the school in the post-war period and of its mechanism of production. The conclusion offers some reflections about the state of the art of the historical-educational research in Italy, with a closer look at the history of the school-publishing and the history of the school.
\end{abstract}

\section{Introduction}

In the last decade, historians of the nineteenth- and twentieth-century Italian school have been paying a particular attention to the line of research related to the publishing for the school and textbooks, which have been explored through a historiographical multidisciplinary approach and thanks to an even more systematic use of the sources, both archival and printed ones. ${ }^{1}$

1 G. Chiosso, (ed.), TESEO. Tipografi e editori scolastico-educativi dell'Ottocento, Milano, Editrice Bibliografica, 2003. Id. (ed.), TESEO '900. Editori scolastico-educativi del primo Novecento, Editrice Bibliografica, Milano, 2008. 
In this perspective, also the issue of the «fascist reclamation» of textbooks has been studied, which is also the main topic of this essay. ${ }^{2}$ The issue - which should be intended as integral part of the organic project of ideological and political control over the school apparatus, and over the moulding of new generation, that was put into action by the Mussolini regime - had fundamental turning point in the Gentile Reform of 1923, which caused important changes with regard to the choices in matter of textbooks, as well as to the productive system of the publishing market (see RD n. 1296 maggio 1923). ${ }^{3}$

In order to understand the strategies which were put into effect by Giovanni Gentile and subsequently by the fascist regime with regard to the production and re-organisation of the book-market, it is useful to analyse the different approach which were used, in the field of textbooks and, more in general, of the publishing for primary and secondary schools.

\section{Textbooks for Primary Schools and the Work of the Fascist Central Commission}

As well-known, books for primary schools had to pass through a complex process that, from the work of the Central Commission for the examination of textbooks, led to the introduction of the State single textbook (Testo unico di Stato), which had important effects not only at a political-ideological and cultural level, but also on the plane of the re-definition of the traditional structures for production and distribution of textbooks.

With the R.D. 11 marzo 1923 it was issued that textbooks for primary schools should be examined by regional commissions and approved by the

2 M. A. Manacorda, Storia illustrata dell'educazione dall'antico Egitto ai nostri giorni, Firenze, Giunti, 2000; R. Sani, The Fascist Reclamation of Text Books from the Gentile Reform to the School Charter of Bottai, «History of Education \& Children's Literature», Vol. III (2008), n. 2, pp. 305-335.

3 With regard to the Gentile Reform, it is possible now to access on line the works by Giovanni Gentile Il problema scolastico del dopoguerra (1919) and La riforma dell'educazione. Discorsi ai maestri di Trieste (1923) that respectively preceded and immediately followed the reform, and in which are illustrated the situation of the Italian educational system and the reasons for its renewal. 
related Directors of education (Provveditori agli studi). Again, a transitory Central Commission - nominated by the Ministry of Education - would have, temporarily, approved the textbooks' lists for the school years 192324 and 1924-25. This Commission installed itself in the weeks following the R.D., and was presided over by the General Director of primary education Giuseppe Lombardo Radice; it was made of teachers, intellectuals and ministerial officers, and it worked full time, going through its tasks 14 months later. The members examined at the beginning the textbooks so-called "complementary" and the "sussidiari" (manuals of history and geography, grammar, arithmetic, bookkeeping, various notions and so on), and then the reading books.

In June 1923 it came out the first partial report, concerning the history and geography manuals, written by Giuseppe Prezzolini and it included the list of approved and/or rejected books. ${ }^{4}$ Other reports followed, about arithmetic and bookkeeping manuals, written by Michele Cipolla, about religion texts, made by a specific sub-commission led by Lombardo Radice, about textbooks aimed at the new provinces, i.e. those ones annexed after the war 1915-18 (this report was signed by, among others, Maria Pezzè Pascolato, Giovanni Maver and Aurelio Palmieri), about "sussidiari", by Lorenzo Sferra Carini, about reading books, by Maria Pezzè Pascolato and finally about texts of "various notions", natural sciences, grammar, hygiene and home economics. In September 1924, the Central Commission of Giuseppe Lombardo Radice presented the final report, which was published in May of the following year (1925).

The Lombardo Radice Commission - which was charged with the examination of a large and varied series of textbooks, including texts which had firstly been published in the last decades of the nineteenth century and frequently reissued, as well as texts dating back to the Giolitti period or to the first post-war period - worked with the aim of imposing a new typology of textbooks, which were able to reflect the didactical and pedagogical trends which underlie the Gentile Reform. This approach explains the attention which was paid by the commission's members not only to the contents and educational models transmitted by textbooks, but also to the linguistic register adopted, to the typographical design and finally

4 A. Ascenzi, R. Sani (a cura di), Il libro per la scuola tra idealismo e fascismo. L'opera della Commissione centrale per l'esame dei libri di testo da Giuseppe Lombardo Radice ad Alessandro Melchiori (1923-1928), Milano,Vita \& Pensiero, 2005, pp. 79-150. 
to the presence of pictures in the text. From these assumptions, the Lombardo Radice Commission worked rigorously, taking into account of any incongruence or lack which texts presented from a didactical, educational and contents viewpoint.

We should mention, with regard to the reading books, that among 459 texts presented by publishers, the Commission definitively rejected a good 222. The other 237 were divided into five categories (but the categories became four, in the relation which was sent to the Ministry of Education):

In the first group (noteworthy books for artistic and didactic value, and well respondent to the spirit of new programmes) - we read in the report for reading books - the Commission has placed 32 works. Among these, the great part has to be corrected in some parts, according to the programmes, and to be presented again within a year for a plain check of the corrections made. In the second group (good and worthy of attention books, as it results from the diverse judgements, but which need a larger re-elaboration according to the programmes; they can be adopted for the school year 1924-1925, but should be presented again next year for the definitive judgement) the Commission has placed 77 works. In the third group (deserving books but rejected as textbooks for primary schools in the daytime, even though they are useful as reward-books, as books for libraries, or textbooks for special schools) there are 32 books. In the fourth group (somewhat good books, but which cannot even temporarily be used in schools because some serious lack or errors, as it emerges from single judgements; they can be presented again as reading books within a year, after revising and correcting; anyway in the new evaluation they will be considered as a new production) there are 16 books. In the fifth group (books with many or some good qualities, but also errors to remove; for the school year 1924-1925 they can be used in the schools where they have been already adopted, but they have, some completely, some in great part, renewed) there are $80 .^{5}$

Judgements about the history and geography manuals were firm all the same: of 317 examined volumes, 212 were approved; 9 definitively rejected; 71 temporarily accepted and only for the school year 1924-25, but on the condition that they should be presented again for the definitive approval, after introducing the changes indicated by the Commission.

More rigid was the selection of the "sussidiari", of the manuals of arithmetic, bookkeeping and religion. On the whole, the "Sussidiari" were judged to be superficial and based on merely factual knowledge, not at all suitable for stimulating «the natural liveliness of children», and, for these

Ivi, p. 289. 
reasons, they were in large part rejected. ${ }^{6}$ The manuals of arithmetic and bookkeeping had rather a more favourable judgement, in fact the Lombardo Radice Commission esteemed that «about one half of them was non respondent with the basics of a good didactics, deficient in communicatory form and linguistic propriety». ${ }^{7}$

As above mentioned, the Central Commission presided over by Lombardo Radice, should have been substituted by the regional commissions, as provided for by the R.D. 11 March 1923, but they were never established. The preferred choice was in fact, as expressed by the C.M. 7 July 1924, to continue to charge the Central Commission with the task to examine the textbooks and to draw up the lists of the approved texts. The R.D. 7 January 1926 reorganized the Central Commission and issued that, in addition to a president and vice-president, it should be made of seven members, to be chosen «from the administrative officials of the Ministry, from the teachers of each level depending from the Ministry, from the school-inspectors and headmasters, and finally from the primary teachers». ${ }^{8}$ The R.D. 22 Mai 1927 modified further on the composition of the evaluating body for primary schools' textbooks, and reduced to five the number of members [one of which was directly appointed by the president of the Opera Nazionale Balilla (ONB)]. The New Central Commission, nominated with the D.M. 15 January 1925 and put under the guidance of the pedagogist Giovanni Vidari, had to examine a lot of textbooks which had been temporarily approved, or sent back, by the Lombardo Radice Commission. With this regard, in the final relation by Vidari Commission we read:

The final result of our work can be summarized in these numbers: Examined books n. 1326. Approved - n. 949. Non approved - n. 277. Well the number of approved books is relatively high: a clear evidence of the fact that the Italian book production shows a continuous improvement. ${ }^{9}$

In the final relation written by Giovanni Vidari, we find a particular interest towards some ideological themes, such as the love for motherland and the emphasizing of the historical events of the Italian Risorgimento

\footnotetext{
$6 \quad$ Ivi, p. 214.

$7 \quad$ Ivi, p. 151.

$8 \quad$ Ivi, p. 57.

$9 \quad$ Ivi, p. 440.
} 
and the Great War, which are presented as founding elements of the civic education of young Italians.

The great event of a war, heroically made and gloriously won, represents the scenario on which emerge in their best light the themes of the patriotic education: the principal facts of the war, the final war, the glorious martyrs, they are almost always all recalled [...]. And the war cemeteries, the grave of the Unknown Soldier and the Motherland Altar are always presented as destination of educative pilgrimages, as the sacred aims, to which the worship and the moved piety of Italians will be turned in perpetuity. Even the meaning of the war, as wonderful fulfilment of a secular effort of redemption of the Motherland, [...], as the greatest collective expression of moral energies of Italians, appears to be touched hither and yon. We suppose that such a meaning not only will easily come out from the lively word of the teacher [...], but that it also become clear and evident in the same pupils' consciousness. ${ }^{10}$

A more direct reference to the fascist principles, will be found in the work of the central commissions which will be established between 1926 and 1927, and anyway their orientation do not represent a break with the previous ones, but rather an accentuation of themes and ideologies which had previously already emerged.

Balbino Giuliano, in fact, when relating about the lines of thought of the Commission which he presided over, on the one hand underlined the continuity with the previous commissions, Lombardo Radice and Vidari; on the other hand, he accentuated the necessity of emphasizing all the more the «ideal principles of the italianità (Italian spirit)» by means of a more direct reference, in textbooks, to the fascist experience and works.

Therefore a sort of binomial was arousing, which matched the «national ideal» with the «fascist ideology»: something that made Balbino Giuliano conclude his Relazione by pointing out how, in many of the «books presented to the Commission's examination, it was lacking that lively feeling of love for Italy, and that fervent worship of her glory, which we should take care of transmitting [...]. Too often in fact, men also of good faith, reveal in their books a kind of worry of talking about fascism». ${ }^{11}$

10 Ivi, pp. 429-573.

11 Ivi, pp. 577-662. 
The Central Commission which was established in 1927, and presided over by Michele Romano, especially insisted on the interpretive line which had been outlined by the Giuliano Commission, at the point that it ended with identifying the «national ideals» with the "fascist ideology», and with making this identification become a criterion for the textbooks' evaluation. $^{12}$

In the final Relazione in fact Michele Romano wrote: "The book written for the primary school and for the integrative courses should not only literally respond to the programme and be clear, effectively communicative, fresh and attractive in adequacy with the presumed or presumable level of the pupils who will use it, but it also should totally reflect the spirit of the programme. The book must be deeply educational, and perfectly fit into the historical period where, and on which, the nation lives: an austere conception of life, which is effort and fight, discipline and sacrifice in virtue of a fervent, supreme, ideal - the Motherland - not seen ab extra, in a rhetoric way, but seen as the daily product of our spirit and actions. From here, the necessity to instil [by means of textbooks] passion for everything heroic and for all the virile virtues, such as loyalty, bravery, work, perseverance, unselfishness, probity, worship for the fathers' religion and respect for authority and hierarchies, even without neglecting kind virtues, which made the gentle whole of the human goodness and generosity: feelings and virtues that, woken up and cultivated in childhood, adolescence and first youth, contribute to actually mould that lifestyle and that "new man" which is expected by the Homeland, especially from this renewed school".

Textbooks should reflect the «fascist spirit», in the most authentic and sincere way, and not with that «despicable kind of rhetoric» which could be noticed in so many texts among the examined ones, especially in books of reading and in history manuals. This objective - Romano suggested - could be fulfil only taking into account «the spiritual and proactive movement of fascism» and taking the cue from the commemoration of the «fascist martyrology, which was so intimately related with the martyrology of the war». ${ }^{13}$

12 E. Gentile, Il culto del Littorio. La sacralizzazione della politica nell'Italia fascista, Roma-Bari, Laterza, 1993, pp. 16-17 and passim.

13 A. Ascenzi, R. Sani (a cura di), Il libro per la scuola tra idealismo e fascismo, cit., pp. 666-697. 
The requests made by the Romano Commission actually met an almost fundamental need, and which had priority for the Mussolini regime, what is confirmed by the promulgation of the R.D. 18 March 1928: at the art. 1 in fact one can read:

History, geography, reading, economy and law manuals for primary schools and for integrative courses of professional training, should respond - in the framework of the programmes in force - to the historical, political, juridical and economic demands, which have established themselves from $28^{\text {th }}$ April 1922 onward.

According to the R.D. $18^{\text {th }}$ March 1928, the new Central Commission which was established in the following weeks and presided over by the vice-secretary of the Fascist National Party (abbr. PNF) Alessandro Melchiori - excluded from examination the reading books (whose renovation had been postponed) and rather focused on the analysis only of the complementary books and on manuals, the "sussidiari", first of all the «manuals of History, Geography, Law and Economy».

In the final Relation, Melchiori gave a totally negative judgement on textbooks that had been examined: "After eliminating those history and geography manuals where we found real mistakes, after cutting out the ones that did not respond to programmes because of serious lacks, excess of matter or errors in expressive style, after rejecting those which appeared unsuitable for the spiritual education of Italian children because of a weak national and fascist spirit, the Commission was in the difficult situation not to be able to choose - among the very numerous textbooks of history and geography that were presented for the examination - any book which was perfectly respondent to the aims of the fascist school, and which deserved a full and complete approval".

At the conclusion of such line of reasoning, in the end of the Relazione the Commission expressed its satisfaction for the decision taken «of finally providing Primary Schools with State textbooks». ${ }^{14}$

14 Ivi, pp. 701-711. 


\section{The State Single Text (1928/1929)}

In November 1928 the Ministry of Education Giuseppe Belluzzo presented to Mussolini the guidelines for the compilation of Single State Texts, which had been elaborated by a ministerial commission, established in the previous months. ${ }^{15}$

It was established that new textbooks should «promote among children a decidedly fascist education and culture» and moreover that they should have bee prepared by «outstanding figures in the field of school and research». ${ }^{16}$ The RD 7 January 1929 introduced in primary schools the State Single Text starting from the school year 1930-1931: the activity of the Central commission for the exam of textbooks, which had started six years before the day after the Gentile Reform, officially ended.

This measure represented, only in general, a break with the choices and the work of Gentile and the same Lombardo Radice. In fact, after a deeper analysis, one can observe that, for example, the same choice to transfer under the state control - through a specific commission of ministerial appointment - the task of selecting textbooks for secondary schools, already represented the premise of a beginning control, directed by the State, on the publishing for the school.

The fact that the first two ministerial commissions had been presided over two pedagogists and teachers, Lombardo Radice and Vidari, was an element, which mitigated, but not changed the concrete. In fact, if on the one hand it was undoubted that both the Lombardo Radice Commission and the Vidari Commission made the textbooks' evaluation on the base of specifically pedagogical-didactical and cultural criteria, avoiding each form of political propaganda or homage to fascism; on the other hand, it emerges clearly that both the commissions exalted the motherlandworship and the history of the Great War, and that their judgements remained within the framework of the severest social conservatism; all these elements ended with building the foundations of the fascist

15 M. Bacigalupi, P. Fossati, Da plebe a popolo. L'educazione popolare nei libri di scuola dall'Unità d'Italia alla Repubblica, Firenze, La Nuova Italia, 1986, pp. 164-187; see also J. Charnitzky, Fascismo e scuola. La politica scolastica del regime (19221943), Firenze, La Nuova Italia, 1994, pp. 393-408.

16 A. Ascenzi, R. Sani (a cura di), Il libro per la scuola tra idealismo e fascismo, cit., p. 30. 
pedagogical model, which was transmitted by the State single texts during the 1930s.

The researches recently carried out on the State single texts, have revealed that some elements - such as the narrative techniques, the mix of diverse literary genres as well as the relation between text and illustrations - actually make of them a specific editorial product, which is guided by a precise pedagogical project, running along the tracks of ideology and propaganda. ${ }^{17}$

After examining the readings for primary schools, it becomes clear the diversity of approaches and languages: particularly significant from this viewpoint are the works by Ornella Quercia Tanzarella for the "I classe" and for the "II classe"; those ones by Angiolo Silvio Novaro for the "IV" and by Roberto Forges Davanzati for the "V classe"; more problematic appears to be the work by Grazia Deledda for the "III classe", at such a point that it will be replaced soon.

The diverse editions of the State single texts show a constant effort to update and adequate the editorial product. Texts offer a dynamic image of fascism; together with the appeal to the values and to the traditional models (the motherland-worship, the respect for the fathers' religion, the respect for the authority, the work centrality, the sense of family and the value of familiar virtues) and the heroic dimension, still alive are the images of the farmers' world and the rural life. Beyond that, there is the will to combine the past with the present, to give to fascism a timeless nature, to recognise it as an all-encompassing reality, able to receive and cover each aspect of the human life. ${ }^{18}$

Totally different was the case of textbooks for the secondary school, which actually is beyond the scope of this essay; anyway we could mention that, if on the one hand no form of preventive control was put into action in secondary schools, on the other hand it should be noticed that, already since the late 1920 s, an incisive and organic policy was started of adapting textbooks to the fascist spirit, as well as of controlling teachers' adoptions and choices of the books, a policy which will be intensified in the following decade, in conjunction with the introduction of the new programmes for secondary schools in 1930

17 Cfr. M. Bacigalupi, P. Fossati, Da plebe a popolo, cit.; D. Montino, Le parole educate. Libri e quaderni tra fascismo e Repubblica, Milano, Selene, 2005; G. Chiosso, (ed.), TESEO '900, pp. LV-LXXIV.

18 M. Bacigalupi, P. Fossati, Da plebe a popolo, cit., pp. 201-231. 
and 1936, respectively by the minister Balbino Giuliano and Cesare Maria De Vecchi di Val Cismon, and, following, with the introduction of the racial legislation of 1938 and the "school charter", the Carta della Scuola by Giuseppe Bottai (1939).

From this perspective, the publishers' resistance, the difficulties linked with the complexity of curricula and the complete variety of didactical organisation of the secondary school, and finally the market's influence, had a deep impact on this situation and therefore caused the adoption of forms of disciplining and control which were different, if compared with those ones that had been adopted in the primary school.

The Day After the Collapse of the Fascist Regime:

the Sub-Commission for Education of the Allied Military Government (1944/45)

During the Resistance a kind of attention had been already paid to the problem of the textbooks' revision and with this regard, in June 1944, Guido De Ruggiero, who had been nominated Minister of Education in the new government, did not hesitate to affirm: "[To the] defascistisation of the school, also by means of the defascistisation of textbooks, a special attention will be paid, both in the case of the adoption of an already conveniently amended book, and in the case of adopting books that, because of local problems, have to be maintained from the previous years. ${ }^{19}$

Actually, the first ideological revision of textbooks used in the fascist period, and the first impulse to the so-called project of defascistisation of Italian schools and school-publishing, was concretely realized by the Sub-Commission for Education of the Allied Military Government (AMG), presided over the American pedagogist Carl Washburne.

As well known, between 1944 and 1945 the Sub-Commission for Education of the AMG drew up the new didactical programmes for nursery-schools, primary schools and teachers training schools, and at

19 M. Corsi, R. Sani, L'educazione alla democrazia tra passato e presente, Milano, Vita e Pensiero, 2002, p. 69. 
the same time it elaborated the criteria for the textbooks' revision in schools of each level and grade. With such a task was charged a ministerial Commission together with a series of regional Commissions for the school, which were established in the territories which were progressively set free and subjected to the Allied Military Government; the commissions were made of teachers and school officers which were nominated by the Regional Education Officers in concert with the Ministry of Education.

From the documents, still largely unpublished, regarding the works of the Sub-Commission and of the regional commissions for the purging of textbooks, some interesting aspects can be highlighted. In particular, in a Relazione about the activities carried out in 1946, is written:

The revision and reprint of textbooks passed through various phases, as it happened for programmes. Similarly, the first phase was preliminary and it only served the purpose to re-open schools as soon as possible without the fascist propaganda. With this aim, immediately were established [...] revision committees, made of trustworthy Italian educators, who could examine the previous textbooks (in secondary as well as in primary schools) and say which ones could be adopted in their integral form, which ones should be banned, and which ones could used, on the condition that some parts were eliminated. ${ }^{20}$

Such a programme for the revision and the reprint immediately revealed to be difficult to be realised, especially in the case of the reading books and the manuals for the primary schools, since it was colliding with the presence of a unique series of textbooks, monopolised by the State and impregnated with fascist propaganda. In the same Relazione of 1946, in fact, one can read:

It is obvious that the best thing to do, would be to completely abolish them; but unfortunately this would have left primary schools without textbooks at all, and the preparation of new ones, even of the simplest kind, would have implied time (and paper). Therefore, the first remedy was to put again in circulation the books of those series which had the smaller infected parts as possible, e.g. ripping away the incriminated pages. The second phase, which rapidly followed, was to re-write and re-print all the series again, after amending fascist elements and substituting with new material, but, apart from this, the books remained the same in the general form [...]. Still, also this method was an expedient, since the books in question, because of their having been conceived since the beginning with a totally fascist spirit, they artificially kept on showing their origin, even after repeated cuts.

$20 I v i$, pp. 65-66. 
Later, the third and last phase necessarily followed, i.e. when the situation become normal again, and enough to allow a free publishing of textbooks for primary schools: then it was finally possible to eliminate also the relics of the old fascist textbooks. ${ }^{21}$

Publishing houses and printers soon organised themselves in order to put into effect this third phase related to the publishing of new textbooks for primary schools.

\section{The Post-Fascist Textbooks}

From the judgements elaborated by the regional school-commissions, it clearly emerges how the publishing for the school of the after-war period was only in part reflecting the guidelines expressed by the didactical programmes of 1945. In fact, if in some cases there was recorded (in the organisation of the subject) an adherence to those guidelines, after a closer examination actually there were strong discrepancies respect to the contents and the educational models which were proposed in the 1945 programmes. In many cases, the publishing houses did nothing but reissue, or only partially change, textbooks dating back to the early 1920 s and, sometimes, even dating back to the last Giolitti period: they often did not take care to remove the clearly anachronistic parts.

Only starting 1947-48 a relatively new publishing production will be realized, both at a primary school and a secondary school level, even though readings, tales and biographical collections for the pupils of the lower school will be characterised for a long time by a scarcity of references to the Italian political and social current affairs.

With regard to this, the writer Gianni Rodari in Ragazzi nuovi libri vecchi, «L'Unità», $30^{\text {th }}$ October 1947, underlined that:

The Italian Republic is more than one year old by now, but if we read the dozens of textbooks and reading books that we are in front of, it seems that our pupils are prohibited from knowing it [...]. [These books] seem to us to be destined to children wearing sailor's suits, with short trousers, like in the magazines of forty years ago, rather than to our children, who were in the cellars under the bombs,

$21 \quad$ Ivi, p. 67. 
and who saw with their own eyes the national insurrection, something like the Five Days of Milan, the partisans killed in the streets and Mussolini hanged up in Piazzale Loreto. ${ }^{22}$

Such statements are directly confirmed, for example, by the particular case of the history manuals. During the Mussolini's twenty-year period, the teaching of history underwent to a process of open exploitation and consequently the history textbooks were charged with a high ideological value. Already the Badoglio government had tried to intervene, with the rules issued after the $25^{\text {th }}$ July 1943 , which downsized the history programmes, establishing the terminus ad quem up to the end of the First World War.

Afterward, the ministerial Commission for the defascistisation of textbooks examined 147 works, for an amount of 200 volumes, including manuals, anthologies of historical readings or historical critic, historical atlases: in November 1944 the official list was published, see the Elenco ufficiale dei volumi esaminati), where the following situation emerged:

1. 18 history manuals (for 30 volumes in total) were forbidden to be used and sold since they were "permeated by fascist spirit and by attitudes suitable with fascism, i.e. emphasis, rhetoric, ecc.»;

2. 54 history text ( 65 volumes in total) were authorised, even though containing «single and separated elements to defascistisate», to be removed;

3. and finally, 75 texts (105 volumes in total) were integrally approved, about which «following the writ n. 4 of the Allied Command, the publisher, under his personal responsibility, has declared that they are exempt from any apologetic reference to fascism». ${ }^{23}$

In the second after-war period, thus, the fascist textbooks were presented again, with only a few modifications, what established de facto a real continuity between fascism and post-fascism: this situation is testified by the case of the 'ultra-fascist' books, such as Vita vissuta. Corso di storia per $i$ licei e $i$ gli istituti magistrali by Francesco Calderaro, which was reissued by the publisher La Nuova Italia up to 1953 .

On the other hand, it has been underlined that, inside the same teachers' class, it was persisting «a culture and a historical sensitivity which was

22 Ivi, p. 66.

$23 I v i$, p. 69. 
still largely linked with the traditional canons of Giovanni Gentile, with the consequent lack of an effective urge for transformation, by the school world». ${ }^{24}$ Such a situation contributed to make less evident the many lacks existing in this field, and the same freedom, which was given to teachers in choosing textbooks (according to DL 16 ottobre 1947, n. 1497, which abolished the ministerial commissions for the control of textbooks), did not have the expected positive results, but it actually ended with confirming a situation of substantial continuity with the past, as we have described so far.

The issue of the revision of the history-manuals and, more in general, of the teaching-programmes for this matter, was undertaken again only during the 1950s, when the ruling class and the public opinion were put face to face with «two events, which were not directly linked with the school life, but which were all the same significant for the future development of the frail Italian democracy: the parliamentary debate about the Scelba law on the suppression of neo-fascist activities (1952) and, on a different level, the emerging of a growing disaffection, by new generations, toward the institutions and the democratic order, something that had originated from the anti-fascist fight and in a large measure was the result of a scarce, or absent, knowledge of the events which had led to the birth of the republican State». ${ }^{25}$

\section{Conclusions}

The scenario that we have here outlined, allows us to highlight a series of historiographical issues and sectors, related to the fascist twenty-year period, which have not been explored yet, or which are worth to be studied in depth. For example, if, on the on hand, there are important studies concerning the strategies and features of the book production for the school put into action by the great publishers of the Centre-North Italy, on the other hand we lack of researches on other important publishers (such

$24 \quad I v i$, p. 71.

$25 I v i$, p. 72. 
as Sandron, Carabba and a great part of the publishing houses from the South-Italy). ${ }^{26}$

Apart from the researches developed about the Florentine and Milanese reality, the state of the research is lacking, especially with regard to the relations among the school-publishing, the cultural and scientific institutions (universities, single secondary schools of the territory), the local lobbies, and the peripheral organs of the PNF.

It should be added that, with the exception of the studies dedicated to the well-known figures of Giovanni Gentile, Ernesto Codignola and Giuseppe Lombardo Radice, it is not well examined yet the role played by those particular intellectuals, who were the editorial collaborators.

A separate discussion should be reserved to the studies of the analysis of the real impact of the fascistisation process on the world of teachers and pupils themselves, and on the cultural and educational models which did the textbooks transmit. Such a kind of approach, in recent years, has renovated the modalities of use of the historical sources. With this regard, significant hints have come from the researches carried out about the school notebooks, and in general on the so-called «school children's writings» of the fascist period (Meda 2009; Montino 2005). ${ }^{27}$

The gaps and the difficulties which emerge when one tries to deepen old trends of research or to follow new study sectors, are the direct consequence of applying a new historiographical approach, which starts from the awareness that the complexity of the historical reality cannot be explored without considering the political and ideological dynamics of a given historical period, and that we should necessarily take into account all that facets and aspects which, more in general, pertain to the cultural context, to the dynamics of the costume and of the mentality too.

26 M. Galfré, Il regime degli editori. Libri, scuola e fascismo, Laterza, Roma-Bari, 2005, pp. 51-57; G. Chiosso (a cura di), La stampa pedagogica in Italia (18201943), Brescia, La scuola, 1997; G. Chiosso, (ed.), TESEO ‘900.

27 J. Meda, D. Montino, R. Sani (eds.), School Exercise Books. A Complex Source for a History of the Approach to Schooling and Education in the $19^{\text {th }}$ and $20^{\text {th }}$ Centuries, Polistampa, Firenze, 2010; D. Montino, Le parole educate, cit. 


\section{Bibliography}

A. Ascenzi, R. Sani (a cura di), Il libro per la scuola tra idealismo e fascismo. L'opera della Commissione centrale per l'esame dei libri di testo da Giuseppe Lombardo Radice ad Alessandro Melchiori (19231928), Milano, Vita \& Pensiero, 2005.

A. Ascenzi, Tra educazione etico-civile e costruzione dell'identità nazionale. L'insegnamento della storia nelle scuole italiane dell'Ottocento, Milano, Vita \& Pensiero, 2004.

M. Bacigalupi, P. Fossati, Da plebe a popolo. L'educazione popolare nei libri di scuola dall'Unità d'Italia alla Repubblica, Firenze, La Nuova Italia, 1986.

A. Barausse (a cura di), Il libro per la scuola dall'Unità al fascismo. La normativa sui libri di testo dalla legge Casati alla riforma Gentile (1861-1922), Macerata, Alfabetica Edizioni, 2008, 2 voll.

J. Charnitzky, Fascismo e scuola. La politica scolastica del regime (19221943), Firenze, La Nuova Italia, 1994.

G. Chiosso (a cura di), La stampa pedagogica in Italia (1820-1943), Brescia, La scuola, 1997.

M. Corsi, R. Sani, L'educazione alla democrazia tra passato e presente, Milano, Vita e Pensiero, 2002.

M. Galfré, Il regime degli editori. Libri, scuola e fascismo, Laterza, Roma-Bari, 2005.

E. Gentile, Il culto del Littorio. La sacralizzazione della politica nell'Italia fascista, Roma-Bari, Laterza, 1993.

M. A. Manacorda, Storia illustrata dell'educazione dall'antico Egitto ai nostri giorni, Firenze, Giunti, 2000.

J. Meda, D. Montino, R. Sani (eds.), School Exercise Books. A Complex Source for a History of the Approach to Schooling and Education in the $19^{\text {th }}$ and $20^{\text {th }}$ Centuries, Polistampa, Firenze, 2010.

D. Montino, Le parole educate. Libri e quaderni tra fascismo e Repubblica, Milano, Selene, 2005.

A. Scotto Di Luzio, L'appropriazione imperfetta. Editori, biblioteche e libri per ragazzi durante il fascismo, Bologna, Il Mulino, 1996.

R. Sani, The Fascist Reclamation of Text Books from the Gentile Reform to the School Charter of Bottai, «History of Education \& Children's Literature», Vol. III (2008), n. 2, pp. 305-335. 
G. Chiosso G., (ed.), TESEO. Tipografi e editori scolastico-educativi dell'Ottocento, Milano, Editrice Bibliografica, 2003.

G. Chiosso (ed.), TESEO '900. Editori scolastico-educativi del primo Novecento, Editrice Bibliografica, Milano, 2008. 
LAMBRos VARELAS

Centre for the Greek Language

\title{
Dictatorship and Literature Teaching in Modern Greek Secondary Education (1936-1940)
}

\begin{abstract}
The following paper attempts to show how Metaxas's dictatorship took advantage, among others, of textbooks on Modern Greek literature in secondary education, in order to reinforce its authority and impose its basic ideological and political directives on the students.
\end{abstract}

\section{Introduction - The History of Modern Greek Literature Textbooks. From 1884 to Metaxas's Dictatorship}

The teaching of Modern Greek literature in Greek secondary education is introduced for the first time in 1884, thanks to the initiative of the great folklorist and then superintendent of the Ministry of Education. N. G. Politis himself designated with absolute accuracy the literary texts that would be taught in each grade as well. Thus, the first textbooks which were published in the same year were simple publications of the Ministrydetermined text and not independent anthologies expressing their publishers' will. ${ }^{1}$ From the beginnings of the $20^{\text {th }}$ century the process of composing the textbooks for Modern Greek literature teaching (known with the title Modern Greek Readings) changed. A competition is announced, always with some directives from the Ministry of Education, and several candidate anthologies are submitted every time, from which one is approved and published as the sole textbook for each grade. The process

1 See it at $<$ http://educmus.ppp.uoa.gr/prothiki/nea1.jpg $>$. 
is modified for the better during the first term of Eleftherios Venizelos (1917 c.e.), in the context of a broader educational reform. Always with regard to the teaching of Modern Greek literature in secondary education, the system of a sole textbook ceases to be the norm. Now, more than one anthologies are approved for each grade, ${ }^{2}$ and the teachers' associations in each school have the freedom to choose one of the approved textbooks and organize their lesson according to which. This preferential situation lasts for approximately 20 years.

\section{Modern Greek Literature School Textbooks in the Metaxas Years}

With the imposition of Metaxas's dictatorship (4.8.1936) the situation in Greek education changes completely toward a more centralized and controlled system, and of course, this situation affects the process of the Modern Greek Readings' composition.

Regarding the composition of school textbooks for the teaching of Modern Greek literature, we witness not only the return to the sole textbook for each grade system, but, chiefly, the application of the most singular mode for choosing anthologized texts, in order to give the ability to the state to designate their content. The School Textbooks' Publication Organization (STPO), which is solely in charge of printing and publishing the school textbooks, is founded in 1937 Laws $952 / 1937$ \& 1644/1939. ${ }^{3}$ In this way, the state gains absolute monopoly for all printed and other kinds of material concerning school. ${ }^{4}$ A relevant competition for the authorship of the new textbooks is again announced, with the expected requirements and commitments in the selection of literary texts: to contribute to the national, religious, and moral education of students and cultivate their aesthetic culture. ${ }^{5}$ Indeed, the competitions take place, several compila-

2 See some examples at $<$ http://educmus.ppp.uoa.gr/prothiki/nea2.jpg $>$ and at $<$ http:// educmus.ppp.uoa.gr/prothiki/nea3.jpg $>$.

$3<$ http://www.history-on-line.eu/greece2.aspx>.

4 Z. I. Kangalidou. Education and politics. The case of the $4^{\text {th }}$ of August regime, Thessaloniki, Kyriakidis brothers's edition, 1999, pp. 118-126.

$5<$ http://www.history-on-line.eu/greece2.aspx $>$. 
tions are submitted, and many are rewarded for the textbooks for each grade (the then-Greek secondary education, the Gymnasium, consisted of six grades, however the textbooks that were published were nine, since for the first, second, and fourth grade, two books were published respectively, in order to cover some transitional conditions in the structure of secondary education), ${ }^{6}$ but the final selection was appointed to special committees of the Ministry of Education. These committees selected the supposedly best texts from the rewarded compilations, in anticipation of the most complete result, since the selection from rewarded compilations was supposed to lead to a perfect outcome. ${ }^{7}$ In reality, however, this system was an ostensible way of controlling the contents of textbooks completely, particularly, the literature textbooks, which are suitable for the shaping of young students' ideology and moral standards. ${ }^{8}$

\section{Propaganda Apparatuses of the Metaxas Regime}

It certainly was not the first time the course of Modern Greek literature and its textbooks were used for the ideological guidance and overall moral instruction of students. Already from the beginning, in the late- $19^{\text {th }}$ century, the school literary canon included texts proper for students to become acquainted with Greek history, from antiquity to their era, so that the

$6 \quad$ Note here that Modern Greek Readings during Metaxas's period were used in Greek education even after World War II, until 1950. In post-war reprintings, the texts of Metaxas himself and all other texts praising directly or indirectly his regime were removed. Six scanned Modern Greek Readings are disposed in www.history-on-line. $\mathrm{eu}$; from these, the books of D and F Gymnasium grades are arrayed in the post-war, slightly revised 1947 editions.

7 V. Io. Toyas, The lesson of Modern Greek language in Secondary Education: A Historical attestation (1833-1967), vol. A-B, Thessaloniki, AUTH, Modern Greek Studies Institute - Manolis Triantafyllidis Foundation, 1988-1990, vol. B, p. 537, and L. Varelas, Modern Greek and translated literature in Helladic secondary education (1884-2001). Brief historical attestation and indexing of teaching textbooks, Thessaloniki, Centre for the Greek Language, 2007, p. 15.

8 M. S. Kelepouri, Literature teaching and the formation of the national self in secondary education: The national dimension of the literary phenomenon's social function. $\mathrm{PhD}$ dissertation - School of Philosophy and Education / Department of Education, Thessaloniki 2006, passim. 
patriotic sentiment would be reinforced. In the following years, parallel to aesthetic education, ideological guidance was always part of the goals and aspirations of the Modern Greek literature class, as well. ${ }^{9}$

In the Metaxas period, however, the ideological guidance through school textbooks reaches its peak. Besides, the regime stated clearly in its laws that "the National and moral education of the youth is a task of the State," and that "The State aims at this education through National Education and the National Youth Organization of Greece". ${ }^{10}$ In reality, as it will become evident later, school textbooks are used as a propaganda apparatus of the Metaxas regime. Metaxas's dictatorship, as well as the German and Italian Fascist regimes, activated an organized propaganda system, in order to inflict their ideology. The conclusion from Marina Petrakis's study, who examined the issue of Metaxian propaganda systematically, shows the following:

E Tetarti Augoustou (The "Fourth of August") regime (as Metaxas' dictatorship was known after its "birth" date) was an authoritarian regime which owed its existence to King George II and worked towards creating a "New State" based on lost supreme values and ideas. The realisation of this goal necessitated the adoption of many fascist and Nazi features like centralised state, the creation of a powerful youth movement, the suppression of political life, austere censorship and complete control of the means of mass communication. Above all it necessitated the mobilisation of a powerful propaganda machine able to proceed the manipulation of the Greek masses and disseminate to them the themes and ideology fostered by the regime, hoping at the same time to obtain their support. ${ }^{11}$

To achieve its goals, the regime used radio, theatre, and cinema propagandistically. We now have at our disposal the remarkable already quoted studies of Petrakis and Angelis which examine how Metaxas and his collaborators utilized all these means, in order to shape the profile of a charismatic leader for the Captain (Metaxas), although not in the model

9 For an illustration of this claim, you can read the fifth chapter (pp. 204-229) of Theophanis Kapsomenis's PhD thesis on The portrayal of Alexander the Great in $19^{\text {th }}$ and $20^{\text {th }}$ century Greek bibliography, Aristotle University of Thessaloniki, 2004 (section "Schoolbooks"). The aforementioned $\mathrm{PhD}$ thesis is freely accessible online in the following URL: <http://cds.lib.auth.gr/submit/archive/Griza/gri-2004-368.pdf>.

10 Article 1 of Law 1798/1939; see also V. Angelis, "Why are people rejoicing and smiling, father..." "Lessons in national education," and Youth propaganda in the years of Metaxas dictatorship, Athens, Vivliorama, 2006, p. 72.

11 M. Petrakis, The Metaxas myth. Dictatorship and Propaganda in Greece, London, I. B. Tauris and Co Ltd, 2006, p. 1. 
of the stately personalities of Hitler and Mussolini (Metaxas had neither their stature, nor their rhetoric ability; he was aged, short, overweight, and a rather mediocre orator) but as a fatherly figured which embraced magnanimously and fondly each social class, especially workers and peasants, as we will see later.

Parallel to the aforementioned means, the regime utilized propagandistically the important institution of education. The course of State Education (which emphasized the contribution of the Fourth of August and Metaxas himself in the country's progress, as well as the school textbooks of the already-known humanities courses (literature, history, religion) were completely suitable to the ideological, political, and moral shaping of children, toward the direction the regime desired.

\section{The Modern Greek Readings of Metaxas's Dictatorship}

The Modern Greek Readings were published during the three-year span of 1938-1940, that is not immediately after the imposition of the regime, but in a "maturation" phase of its propagandistic methods. The opportunity to rearrange the anthologized literary texts was given for the first time, while the anthologists also had the ability to include texts of their own, thus distorting the school literary canon. ${ }^{12}$ Some of the anthologists were welldisposed towards the regime and included their own "literary" texts, which were of doubtful aesthetic value and promoted the principles of the regime, or texts of others who praised the regime's commemorative demonstrations. One can find such propagandistic texts by the anthologist Theodoros

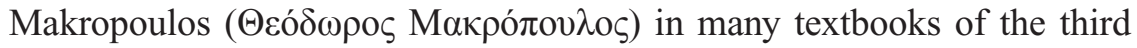
and fourth Gymnasium grade. It is true, nevertheless, that the anthologists, no matter whether they liked the regime or not, had little responsibility for the final picture of the Modern Greek Readings, since the committees that had undertaken the final selection of texts were not giving account of their actions to anyone except the higher administrative officers. Moreover, the strict censorship that had been imposed left no margin for reactions on the

12 V. Io. Toyas, The lesson of Modern Greek language in Secondary Education, cit., vol. B, pp. 540-541. 
anthologists' part, therefore all reviews for the particular textbooks was flattering. Nevertheless, the assignment the textbooks' publication to STPO improved their appearance significantly compared to the past, since their artwork and portraits of the authors) was assigned to painters. In addition, the textbooks are decorated with paintings by noted $19^{\text {th }}$ century Greek painters (Nikolaos Gyzis, Nikiforos Lytras, Georgios Iakovidis) portraying scenes from Greek life, as well as with Nelly's photos, with themes from the King's Guard Evzones and from the Greek country

\section{The Youth's Ideological Guidance}

Modern Greek Readings are addressed to Gymnasium students, namely youths of 13-18 years old. Metaxas's interest in the youth's ideological guidance was very intense, since he rested a lot on it for the consolidation of his regime. Historians studying Metaxas's dictatorship claim that his regime was a "conservative dictatorship" and not a Fascist movement, since it lacked a popular basis. Therefore, Metaxas, in order to obtain the required popular appeal that would confirm the king's support and would secure his regime's longevity, hastened, by partially following actions of the Italian and German Fascist regimes, to create the National Youth Or-

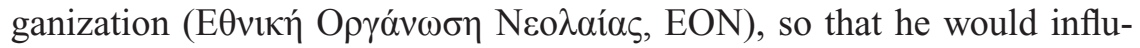
ence the young population and obtain the popularity he lacked. Again, Petrakis claims that:

The formation and function of EON Ethnik[i Organosi] Neolaias (National Youth Organisation) Metaxas' "Golden Children" which represented his most systematic effort to built the most popular base he lacked, ensured the assimilation of the regime's ideology and its most successful propagation. The unification of Greek youth under a well controlled organisation which left amble room for exploitation and manipulation guaranteed the dissemination of the themes associated with the regime. ${ }^{13}$

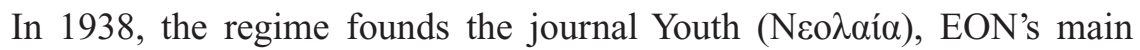
organ, through which the ideological guidance of the organizations' members, in reality all the young Greek children, is attempted. The main content of the journal is described by the chief editors as such:

13 M. Petrakis, The Metaxas myth. Dictatorship and Propaganda in Greece, cit., p. 4. 
agreeable readings, derived from the most characteristic periods of our history [...] excerpt from the most beautiful pages of our ancient, modern and more recent history, heroic figures, sacred places [...] our fathers' Religion, the Greek land, the Greek sea, the Greek mountains, our manners, our customs [...] encyclopaedic issues and Greek figures that served Art and Letters [...] the great current National and State events [...] special recreational pages [...] the activity of local EON establishments throughout Greece through mail as well[...] In "Youth" even our young correspond each week with the Captain by reading his wise counsel and advice. (16.3.1940 issue). ${ }^{14}$

If one notices the above description of the content of Youth and the contents of the Gymnasium's first four grades' Modern Greek Readings, he will discover that there many analogies between the two publication concerning their propagandistic goal. Certainly, they are different means; the one is an official propagandistic organ, while the other is a school textbook; one is filled with crude and unsophisticated didactic texts, while the other is filled mainly with texts from the Modern Greek literature canon; yet there are analogies.

\section{Ideological and Philological Goals of Modern Greek Readings' Literary Texts}

Let us now see the Modern Greek Readings of Metaxas's period closely. The arrangement of anthologized texts in thematic units indicates the main ideological goals of these textbooks as well. In the first four grades' textbooks, the contents are arranged in the following thematic units: "From religious life," "From ancient Greek life," "From modern Greek life," "From family and social life," "From Greek landscapes," "From Greek nature and the life within it." In brief: patriotism, religion, family, rustic Greece. The selection and arrangement of texts gets a more obvious philologic aim only in the last two grades' textbooks: in the fifth grade, texts are anthologized in chronological order for the first time, from the fall of Constantinople (1453 B.C.) to the modern era, while in the final grade, texts are selected from various literary genres, so that students will be informed about the diversity of textual genres (short

14 Excerpt from V. Angelis's “Why are people rejoicing and smiling, father...”, cit., p. 107. 
story, narrative, account, prose poem, study, literary review, satirical poetry, verse drama, etc.). Works from foreign/translated literature are also anthologized in fifth and sixth grade textbooks, so that students will become acquainted with classic works and authors of world literature, even though some authors are selected by the yardstick of their philhellenism (Byron, Cervantes, Dante, Goethe, Hugo, Kipling, Mistral, Schiller, Shakespeare, etc.).

\section{Greek Fatherland Worship}

The entirety of anthologized texts shapes a moralist climate in the context of the aforementioned main directives. Texts by ancient didactic writers (Plutarch's biographies of model figures), as well as revisions of anonymous moralist texts from the French, English, and Russian literature are employed towards this goal. Most of these directives did not appear then for the first time. The cultivation of religious sentiment was always within the aims of school textbooks. The same applies for the promotion of familial bonds, the joy of contribution to society, humanitarianism, and charity. As we have already seen, the attempt for the invigoration of patriotism through the inclusion of the age-long Greek history (antiquity, Byzantium, Ottoman conquest) was dominant. However, now there is an important difference in accent, which is explained if we consider that these textbooks were arranged in a period when the clouds of World War II are visible on the horizon. Therefore, it is no surprise that there is an atmosphere of self-sacrifice for the fatherland, characteristic of many anthologized texts, as in the following excerpt, which reminds of ancient Spartan mothers' attitude toward their sons when they left for war:

- Go, my child, with my blessing, said she. Obligation towards the Fatherland is far more important than duty towards father. Seek to do your duty. If I learn that you were killed, I may possibly not die. If I learn that you flinched, I will die of shame.

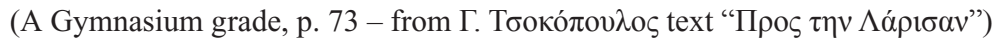

Even already known patriotic texts reach a higher level of gravity. For example, noted poet Georgios Drosinis's poem "The Soil of Greece," which 
is praising the fatherland's soil, was anthologized in older school textbooks as well (from 1909 c.e.). I am citing it in a prose translation by C. A. Trypanis: ${ }^{15}$

Now that I am leaving and shall go to foreign lands, and we shall live apart for months and years, let me take with me something from you too, my blue beloved homeland. Let me take an amulet to protect me from all sorrow, from every evil, an amulet against sickness and death, a little, only a little of the soil of Greece.

Soil that the night-breeze, the rain of May moistened; summer gave it fragrance; blessed earth that, if only touched by the heavenly grace of the Pleiades and the warm kisses of the sun, yields the fragrant vine, the golden corn, the green laurel and the bitter olive.

Honoured soil, which was dug for the foundation of a Parthenon; glorious soil, dyed red by the blood of Souli and of Marathon; soil that buried holy relics from Missolonghi and Psara, soil that will give me, a young boy, courage, pride, glory and joy.

I will hang you as an amulet on my breast, and when my heart wears you as an amulet she will take courage, be helped by you, and will not be bewitched by other foreign beauties. Your grace will give me strength; wherever I turn, wherever I stand, you will kindle in me only one desire: to return to Greece.

And should it be my fate -a black desolate fate- to leave and never to return, I will finally ask you to forgive me, and give you my last kiss. So, if I die in foreign lands, the foreign tomb will sweeter if you will be buried with me on my heart, beloved soil, soil of Greece. ${ }^{16}$

However, when this patriotic poem coexists in the same textbooks with the following appeal by dictator Metaxas to students, it ceases to be simply a love poem for the fatherland and transforms into nationalist frenzy:

When you love Greece, you love yourself. One day, when you grow up, you will have great possessions to give, and the greatest one you have, the best and most beautiful, is your life. If you must give your life, you will give it not only because of enthusiasm, but because this is the nature of things. Because, if you do not give your life one day, those who will come after you will be slaves, they will not be Greeks; they will be slaves [...] You must eliminate every tainted person who speaks or will dare to speak to you against the ideals of the Fatherland. ${ }^{17}$

15 The Penguin Book of Greek Verse. Edited by Constantine A. Trypanis, Penguin Books 1971, pp. 533-534.

16 A Gymnasium grade, pp. 76-77.

17 C Gymnasium grade, pp. 65-66. 
Similarly, other texts gain a special sense of timeliness. The anthologist Th. Makropoulos's text "The Brave Greek boy" («To yevvaío

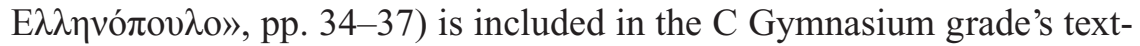
book. Makropoulos was not a skilled writer but the law enabled him to include texts of his own. This particular text described the heroic stand of a Greek boy against the Roman conquerors in ancient Corinth. The incident is based on the binary opposition of "noble Greeks" / "uncouth and uncivilized Romans", and it is certain that during the Greco-Italian War (Fall of 1940) it reached another dimension and boosted the Greek boys' morale.

\section{The Sympathy for the Peasantry}

Texts praising industry and encouraging the young to labour joyfully also gain another dimension. Texts of such thematic content were already included in previous years' school textbooks, but the moment now is different and no longer so innocent. For example, the important writer Stratis Myrivilis's poem "The work song," written in 1939, and recited at the Panathenaic Stadium on the occasion of commemorating the Metaxas regime's third anniversary (4.8.1939), is included in three (!) Modern Greek Readings: those of the third (p. 121), and of the fourth and fifth (pp. 204-205) Gymnasium grades. The poem being about "the festival work," connections with Fascist "Kraft durch Freude" festivals/ exhibitions are inevitable. Nevertheless, an overall atmosphere of joy and optimism drives most of the Modern Greek Readings' texts, an atmosphere also evident, among others, in the EON members' "Ten Commandments." The EON's Decalogue is also included in Modern Greek Readings, and the seventh commandment, which should be obeyed by each member of the organization, was "Always be cheerful, not only in games, but also in the execution of every service". ${ }^{18}$

There is no doubt, however, that Modern Greek Readings were also openly used for the promotion of the regime's ideology. Except for the EON's "Ten Commandments" there are also several excerpts from dictator Metaxas's addresses and speeches to school and university students and

18 B Gymnasium grade, pp. 153-154. 
athletes in the school textbooks. ${ }^{19}$ In the same books, the regime's Anthem ("Why are people rejoicing and smiling, father...") and narrations from EON's activities are included. ${ }^{20}$ Also included are excerpts from Metaxas's biography as well as text describing and praising the regime's commemorative (that is propagandistic in reality) demonstrations. ${ }^{21}$

The exploitation of Modern Greek Readings for the promotion of the regime's main political choices is attempted either directly or indirectly. The special emphasis given to the anthologization of texts sympathetic to the peasantry is characteristic in this respect.

The concern of the Metaxas regime and Metaxas himself for the peasantry is great, as with all interwar period's autarchic regimes. According to researcher Jon Kofas, Metaxas hoped that class conflicts would be absorbed through the peasants' support:

The peasantry concerned the chief [Metaxas] more than the working class, and he lived under the illusion that he saved it from its devasted condition. He believed that the agrarian sector was the backbone of the country's economy, and he charged that under the democratic administration it was grossly neglected. He accused the parliamentary governments of burdening the peasants with heavy debts and of being insensitive to the needs of the rural sector. He promised to revive agriculture and alleviate the eternal peasant distress by applying corporative methods to rural economy. He proposed to establish agrarian associations whose objective was to "unify" the landless peasant with the large land owner. In other words, he wanted a peasantlandowner collaboration, in the same respect that he established a worker-employer collaboration, in the urban sector, with the state determining the relationship of the opposing classes. The state, therefore, and not any particular class was the supreme entity in society. ${ }^{22}$

Metaxas's systematic interest in the peasantry is in step with the European (German, Italian) Fascist governments' respective interest. It is no coincidence that Metaxas himself (like Hitler) had been proclaimed the country's "Prime Peasant." The immediate goal of these actions, leaving aside the absorption of class conflicts, was common: the increase of agrarian production, so that the country's self-sufficiency is ensured. In order for

19 B Gymnasium grade, pp. 152-153, C Gymnasium grade, pp. 65-66, E gymnasium grade, pp. 172-174, and 174-176.

20 C Gymnasium grade, pp. 70-72, and 118-120.

21 C Gymnasium grade, pp. 67-70, 70-72.

22 J. V. Kofas, Authoritarianism in Greece. The Metaxas regime, New York, East European Monographs, Boulder, 1983, p. 61. Also see V. Angelis, "Why are people rejoicing and smiling, father...", cit., pp. 214-217. 
this goal to be achieved, the agrarian people had to be aided financially, the urban pull wave had to be contained, and primarily, love for the native land and Greek nature had to become popular ideology.

Modern Greek Readings were employed for the achievement of this goal as well. We have already seen that two large thematic units, under which literary texts were assembled in the first four Gymnasium grades' textbooks, were referring to "Greek landscapes" and "Greek nature and the life within it." Texts highlighting the flight from the polluted and sinful capital and praising the pure and redemptive province are anthologized:

The waves kept heading toward the mole; the first wave cooler than the second, the second foamier than the first. They sprinkled and washed my soul, like the Pool of Siloam. And I wished that all those Athenians were there, [I wished that they] let go of their soul's burden and dust, which defiles their labour's sacred sweat. [I wished] that

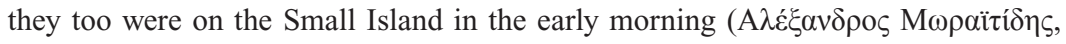

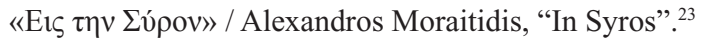

Parallel to that, texts describing Greek provincial regions are anthologized systematically, so that student's love for their native homeland is boosted. Moreover, texts about the flora and fauna of rural Greece (texts about the country's plants and animals) are included. More importantly, though, texts related to the agrarian cultivation, especially wheat cultivation and bread production (ploughing, sowing, harvest, milling, bread production). This tendency's connection to a respective central political choice is proven by the fact that an unedited circular by Metaxas himself, through which he appeals to EON members by encouraging them to see to land cultivation themselves, is included in the third Gymnasium grade's textbook. This circular was released in September 1939, when World War II had already broken out, and the need to ensure the country's self-sufficiency, chiefly in grains, appeared urgent. The main slogan of the period was "Every inch of Greek land must quickly produce something," as we see in Metaxas's circular, which is anthologized in Modern Greek Readings:

I appeal to Greek EON members, and especially to you, male and female phalangites, who live in our rural country, and I invoke your devotion to me and your oath for the faithful execution of my orders, to request from each one of you to offer all your enthusiasm and all of your youthful powers to the complete success of my attempt to give our country full sufficiency of the material means necessary for life.

23 A Gymnasium grade, p. 150. 
You, who know that when I request something, it also must be done, because what I require to be done is a national urgency, I am certain that you will embrace this order of mine, to transform Greece quickly into an agricultural camp where no corner will remain uncultivated, with all your enthusiasm and all your strength, and will let not even one moment to go by aimlessly and away from the fulfillment of our goal.

I request from all you, men and women, to become the vanguard of the army for the safeguarding of our country's financial longevity. I request from you to fling yourselves high-spiritedly and enthusiastically into the task of cultivating even the last corner of our earth, which is the only one that will bring life's sufficiency to our land.

At home, at church, in the street, at the field, at school, wherever you may be, I request you do not let one moment without reminding this duty to everyone. You first will always give the example for the total success of this national endeavour. With actions and words, you must be convinced and convince that neither your house fence, nor the churchyard, nor your schoolyard must remain uncultivated. Every inch of Greek land must quickly produce something. Even a potato, an oka of grain fruit, a kilo of wheat. And I demand from you to always the first in this campaign. No male or female phalangite must forget for once this goal from now on. The Greek land's cultivation to the highest level constitutes for each one you, male and female, a national duty, identical to the soldier's duty. And every Greek phalangite, who, as I am firmly convinced, knows to how to execute his national duty, I am absolutely certain, will execute these orders of mine precisely, with that enthusiasm and way, which he has so many times proven to me he possesses. ${ }^{24}$

\section{Exclusions of Writers}

It is self-evident that writers such as C. P. Cavafy (1863-1933), with his erotic poems, had no place in such a moralistic and ideologicopolitical context. Indeed, while a number of Cavafy's poems had been anthologized in previous years' Modern Greek Readings (around 1930), in the Metaxas period's respective textbooks we find not one poem of his, although several of his historical poems could have easily been included in the ancient / Hellenistic history thematic units. We do not know whether the anthologists had included Cavafy's poems in their rewarded anthologies, it is certain, however, that even if the poems had been anthologized, they were not selected by the Ministry of Education committees that had been

24 C Gymnasium grade, pp. 160-161. 
assigned with the final arrangement of the textbooks' contents. The important Greek interwar period poet K. G. Karyotakis (1896-1928), whose pessimistic poetry would be in conflict with the cheerful, optimistic, and euphoric atmosphere the regime desired to shape and dominated in the textbooks, is also absent. Finally, the later famous writers, poets and novelists of the 1930s generation (G. Seferis, Od. Elytis, An. Empeirikos, M. Karagatsis, G. Theotokas) are absent, their absence however is expected, since they had just began publishing their works and gaining fame.

\section{Bibliography}

Vangelis Angelis, "Why are people rejoicing and smiling, father..." "Lessons in national education," and Youth propaganda in the years of Metaxas dictatorship, Athens, Vivliorama, 2006.

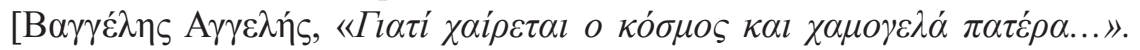

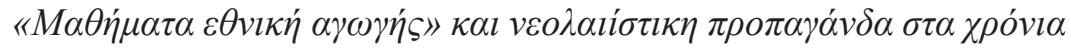

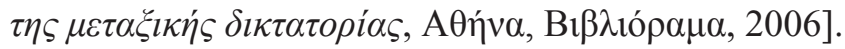

Zafeiroula I. Kangalidou. Education and politics. The case of the $4^{\text {th }}$ of August regime, Thessaloniki, Kyriakidis brothers's edition, 1999.

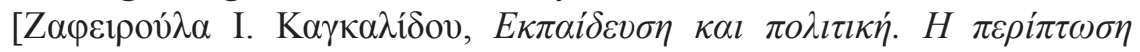

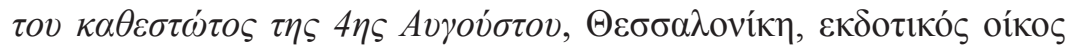

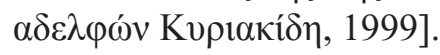

Maria S. Kelepouri, Literature teaching and the formation of the national self in secondary education: The national dimension of the literary phenomenon's social function. PhD dissertation - School of Philosophy and Education / Department of Education, Thessaloniki 2006.

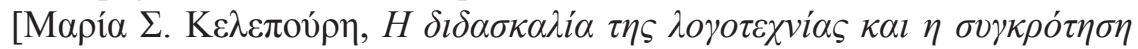

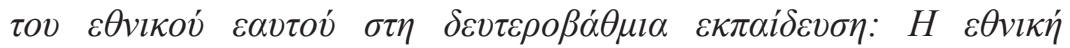

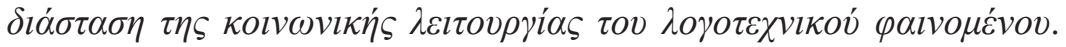

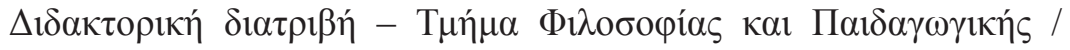

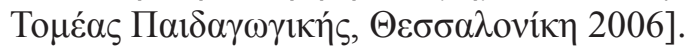

Jon V. Kofas, Authoritarianism in Greece. The Metaxas regime, New York, East European Monographs, Boulder, 1983.

Marina Petrakis, The Metaxas myth. Dictatorship and Propaganda in Greece, London, I. B. Tauris and Co Ltd, 2006. 
Heinz Sünkel - Hans-Uwe Otto (ed.), Education and Fascism. Political Identity and. Social Education in Nazi Germnay, London/Washington 1997.

Vassilios Io. Toyas, The lesson of Modern Greek language in Secondary Education: A Historical attestation (1833-1967), vol. A-B, Thessaloniki, AUTH, Modern Greek Studies Institute / Manolis Triantafyllidis Foundation, 1988-1990.

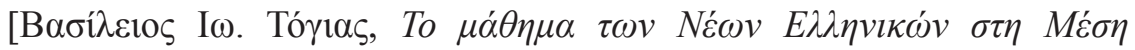

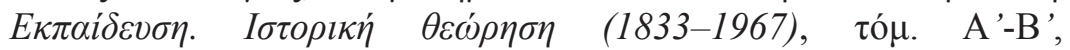

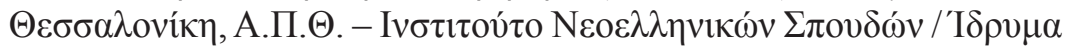

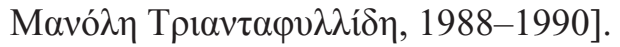

Lambros Varelas, Modern Greek and translated literature in Helladic secondary education (1884-2001). Brief historical attestation and indexing of teaching textbooks, Thessaloniki, Centre for the Greek Language, 2007.

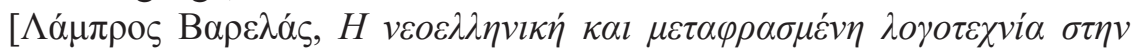

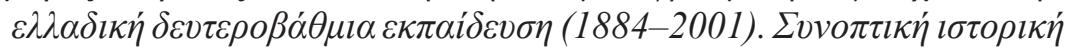

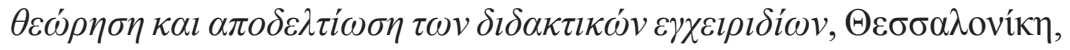

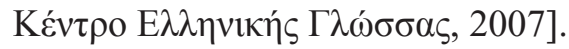



Ana María Badanelli Rubio

Kira Mahamud Angulo

Miguel Somoza Rodríguez

National University of Distance Education (UNED)

\title{
Gender Identities and Political Power in Francoist School Textbooks (1940-1975)
}

\begin{abstract}
This paper aims to examine the way school textbooks contributed to the construction of a particular national feminine and masculine identity during the Franco Dictatorship. The regime's National Catholic ideology impregnated and guided the life of the Spanish people and it deeply penetrated the school practices as well as the contents of school textbooks. The paper has been divided into three sections. The first approaches the construction of the feminine national identity through an analysis of the representation of motherhood in school manuals. The second deals with the construction of the masculine national identity as an ideal, an ambition and, at the same time, a frustration for Spanish men. The third focuses on the construction of both mentioned gender identities through the analysis of images and illustrations. The common denominator is the emphasis laid on the emotions transmitted and found in both text and images as the key strategy through which children are taught, guided and persuaded to think, believe, feel, and behave in a certain manner according to their sex.
\end{abstract}

\section{Introduction}

Traditional culture maintains and is grounded upon gender and sexual inequality, an asymmetry strongly legitimated by religious, political, and biological discourses, which are embodied in theories, social practices, and institutions, including the main socialising agency of modernity: the school. Through this instrument, policies of gender and sexual differentiation were 
implemented, which pursued the crystallisation and maintenance of identities based on the inequality of attributes, rights and obligations, access to material resources, and positions of prestige and power.

In the paper we aim to point out the principal aspects of the construction of masculine and feminine identities through the textual and iconographic analysis of the school textbooks of the Francoist regime. School textbooks emerge as key documents for historical-educational research and as precious material components of the School Culture. The creation of a variety of national and international research centres dedicated to this kind of research supports our claim. This period is especially relevant for research on gender for two main reasons:

- because Francoism pursued, through coercion and indoctrination, the recovery of traditional political and moral values related to patriotism and Catholicism;

- because a significant number of individuals from the current generations were schooled during this period, which could perhaps help to explain the problematic relationship between the sexes, in particular, the persistence of discriminatory and violent conduct in a society supposedly based on egalitarian and democratic values. Francoism, at the same time, recovered, adopted, supported, and maintained the traditional mentality of past centuries regarding the place, the role, and the education of women.

A clear example of this outlook can be found in two of the educational classics. The first one is entitled La ciencia de la muger al alcance de las niñas (The science of women at the reach of girls) (1859). It displays the educational ideas of the pedagogue Mariano Carderera. The second one projects the thought of Josepha Amar y Borbón, a relevant woman in the Enlightenment period in Spain, in her Discurso sobre la educación física $y$ moral de las mujeres (Speech on the Physical and Moral Education of Women) (1790).

This research focuses especially on the intentional use of certain feelings and emotions in the school curriculum and on the didactic materials as an instrument for the inculcation of values and the configuration of mentalities. The emotions constitute one of the key elements necessary to understand human conduct and this is the premise upon which this investigation has been based in order to discover the emotions which have been employed in school textbooks and which favour, avoid, or maintain 
certain attitudes and behaviours. The very etymological root of the word emotion comes from the Latin verb emovere (move, remove), and indeed in all emotion there is an implicit tendency to act. Such feelings and emotions were selectively employed depending on whether the reader was male of female, emphasising the concepts of love, pride, and shame for women (orientated towards maternity and the private family sphere), and the concepts of hierarchy, honour, and heroism for men (in this case directed towards the public sphere of the political community and economic activity). Feminine submission and masculine violence, far from being "natural" attributes of the sexes as the traditional mentality maintains, are actually the effects of a prolonged socio-political, deliberately discriminatory educational program, with the ultimate goal of legitimating a system of relations of domination which imprisoned both sexes, albeit with clearly unfavourable practical consequences and roles for women.

But underlying of all of them there lay a more basic emotion, which was perhaps the most frequently employed during this historical period: fear, which contributed to strengthening the nature of the Franco regime. Fear guaranteed obedience to the established military and religious powers, and the Francoist school curriculum spread this emotion abundantly and methodically, with differentiated objectives (opposed but complementary) depending on the gender and social class of the individual to which it was addressed. The image below aims at showing how the teaching and transmission of the feeling of fear towards God was carried out together with the feeling of love towards the parents. The example is taken from the reading book Lecturas infantiles ${ }^{1}$ (Children's readings) from Ezequiel Solana which survived during Franco's regime. ${ }^{1}$

The first two maxims tell the young reader that "The fear of God, my son, is the principle of wisdom" and that "The love for the parents is the first duty of the children".

The paper is structured into three separate convergent sections: the first, entitled The Construction of Feminine Identity through Motherhood. Analysis of the Representation of Motherhood in Primary School Textbooks under the Franco Regime, focuses on the feminine gender, especially the sphere of motherhood as an emotionally charged social phenomenon and symbol; the second, entitled Masculine Identity in School Textbooks

1 E. Solana, Lecturas infantiles. Primer libro de lectura corriente. Madrid: Editorial Escuela Española, 1961 (Edition 71). We have found the same text in page 5, although with a different illustration, in the editions of 1925 and 1940. 
during the Franco Regime analyses the main aspects of the construction of masculine identity; finally, the last section, The Role of Illustrations in the Construction of Gender Identities, is an iconographic analysis of the images displayed in school textbooks, paying close attention to the images in which emotions are associated with behaviours considered to be appropriate for the feminine or masculine gender.

\section{The Historical Context}

Francoism (1936-1975), initiated as a military insurrection against the government of the Second Republic (1931-1939), achieved power after a bloody civil war and maintained a political system based on direct and open repression until the end of its days. It was institutionalised as a military dictatorship established upon the military forces in alliance with the Catholic Church, the great landowners as well as the leading financial and industrial capitalists, and a mass of urban and rural middle classes. The latter also suffered the burden of illiteracy of the past which placed them in a position of total dependence and submission. There is an almost unanimous consensus amongst historians in characterising it as an authoritarian military dictatorship stamped by a national-Catholic ideology. It included Fascist organisations although, as the regime established itself and became institutionalised, they lost influence within its internal structure of power in favour of other sectors, such as the Catholic Church. It was also Catholic sectors that led a technocratic process of economic modernisation which was initiated in the 1960's.

The support of the Catholic Church from the very beginning of the military insurrection against the Republic is evident, to the extent of providing the ideological legitimacy of a "crusade for national salvation" to Francoism. Especially after the end of the Second World War, given the need to distance itself from the defeated Fascist powers, the Franco government granted the Catholic Church the undisputed leading role in the field of education. The law of Primary Education in 1945 constitutes a clear manifestation of the firm alliance between the Francoist regime 
and the most radical Catholicism. ${ }^{2}$ From this point onwards, and for many years, a National-Catholic rhetoric and practice, characterised by chauvinism, militarism, and ultramontanism, took control of the entire educational system. From the perspective of Francoist ideology, the objective and the ideal model for society was the return to a traditional society, its values and principles, shattered by the arrival of the Republic. It is not until the 1970 Education Act $^{3}$ which Spain sees the beginning of change in education, following the onset of social and political transition.

Education during this period has been the object of numerous investigations and, in fact, the study of textbooks and the ideology they transmitted has produced an increasing number and variety of publications. ${ }^{4}$ Here we merely wish to focus on the general framework of thought in which Francoist rhetoric was inscribed, on those aspects which allow us to reconstruct a certain "mentality" or "social imagination" which was not created by Francoism but appropriated from traditionalist and conservative thought: an exaltation of values from the ancien regime which it reproduced and amplified with very few innovations, amongst them, the inclusion of Franco himself in the "historic pantheon" of Spanish history, for his defence of Catholicism as the very essence of the Spanish nation and the keystone of its "indissoluble" cultural and territorial unity, thereby reproducing the clichés which the Spanish educational system had transmitted since the nineteenth century and the early decades of the twentieth, with the exception of some changes introduced during the period of the Second Republic.

The exemplary study on political socialisation during Francoism through school textbooks carried out by Gregorio Cámara Villar, ${ }^{5}$ as well as the analysis of their ideological content by Manuela López Marcos, ${ }^{6}$

2 17th July 1945 Primary Education Act. Official Bulletin of the State, number 199, of $18^{\text {th }}$ July 1945.

31970 Law of 4th August on General Education and Financing of the Educational Reform. Official Bulletin of the State, of $6^{\text {th }}$ August 1970.

4 The MANES Research Centre contains a Collection of Studies published by the Publishing House of the UNED. Many of these works deal with education through school textbooks during the Franco regime.

5 G. Cámara Villar, Nacional-Catolicismo y Escuela. La socialización política del franquismo (1936-1951), Jaén, Hesperia, 1984, pp. 298-299.

6 M. López Marcos, El fenómeno ideológico del franquismo en los manuales escolares de enseñanza primaria (1936-1945), Madrid, UNED Ediciones-Proyecto MANES, 2001. 
that of Navarro Sandalinas on primary education, ${ }^{7}$ or the more recent one by Emilio Castillejo ${ }^{8}$ on the symbolic violence present in curricular contents and their legitimating function for the authoritarian political order agree that the fundamental ideological objective of Francoist school textbooks was political, moral, and religious indoctrination.

Cámara Villar identifies a series of themes which appear systematically in textbooks and which coincided with the central ideological tenets of Francoism, of which here we would like to highlight the following:

1) exacerbated nationalism, in which Spain is presented as the centre and model for the world due to its essential spirituality, as opposed to the materialism of other nations;

2) the identification of Catholicism with the nation, and Catholic values as the foundation of all positive values;

3) the transmission of a hierarchical and authoritarian conception of social and political reality: the legitimating of elitism, aristocracy, militarism, the primacy of duties over rights, and amongst the former, obedience, hierarchy, discipline, and service;

4) an organic image of society based on Catholic corporativism: the legitimation of social inequality, presented as something natural and sanctioned by religion. Education in general and enseñanza primaria in particular, suffer and feed the backwardness of Spain.

To sum up, the objective of this paper is to show the configuration of gender identities through school textbooks at the primary level (what is usually known as "published curriculum") as part of the institutionalised educational procedures of Francoism. These texts aimed to transmit the worldview of a traditional and even pre-modern society, inserted in the structures of social as well as gender inequality and domination which Francoism embodied. We shall therefore focus for this purpose on the period from 1940 to 1965 , since it is the most characteristic and representative of the National-Catholic ideology.

7 R. Navarro Sandalinas, La ensenanza primaria durante el Franquismo (1936-1975), Barcelona, Promociones y Publicaciones Universitarias, 1990.

8 E. Castillejo Cambra, Mito, legitimación y violencia simbólica en los manuales escolares de Historia del franquismo. Madrid, UNED Ediciones. Proyecto MANES, 2008. 


\section{The Construction of Feminine Identity Through Motherhood. An Analysis of the Representation of Motherhood in School Textbooks}

This paragraph focuses on the analysis of the representation of motherhood as a symbolic phenomenon and an emotionally charged social symbol and of the maternal universe presented in school textbooks during the first and part of the second phase of the Franco Dictatorship (1939-1953) in Spain. ${ }^{9}$ The hypothesis is that the phenomenon of motherhood was employed and manipulated by the New State and by the Catholic Church as an instrument for the transmission of their respective ideologies (patriotism; Francoism; Catholicism); and for the achievement of their political ambitions (demographic growth; maintenance of the status quo; legitimacy of the Regime; construction of new national identity, return to old, traditional values, etc.).

The content of the school textbooks reveal some key aspects about the image of childhood as a social category during Francoism, in particular about feminine childhood. The schoolbooks and other documentary sources reflect an attitude towards childhood, with regard to the expectations and demands which adults made on the girls in that period. Childhood is, on the one hand, the flip side of motherhood, in the mother-child relationship; and, on the other hand, in the case of girls, during Francoism and in earlier periods, the entrance and initiation into the universe of motherhood.

Girls of Spain: You are the most beautiful hope of our fatherland. In your heart you carry its greatness or its ruin, just as flowers carry, under the delicate sheath of their petals, the seeds from which sweet and perfumed fruits will sprout. Hammer into your souls the irrepressible desire to make Spain a greater country every day because SPAIN WILL BE WHAT YOU MAKE OF HER. ${ }^{10}$

9 I have opted for a division of the Franco Dictatorship in three periods: 1. The Francoist 'totalitarian orientation' or early Francoism (1936-1945), 2. The regime's National-Catholic prevalence (1945-1957), and 3. Franco's regime in its technocratic phase (1957-1975). The reasons why I stop in 1953 are educational in nature: until 1953 the Spanish school used textbooks published during the Restoration and in that same year, elementary Secondary Education was created, the basis for promoting a public policy for school construction were established, the first national curricula for Primary Education was published, and in the religious arena, the Concordat with the Holly See was signed. It is a significant turning point year for education.

10 A. Serrano de Haro, Guirnaldas de la Historia. Historia de la cultura española contada a las niñas. Madrid, Escuela Española, 1957, p. 192. Italics and capitals belong to the author. Original quote reads: "Niñas de España: Vosotras sois la más hermosa 
The quotation is very explicit and illustrative of the message and language, both characterized by a dense emotional burden. The words are pronounced by the Inspector of Primary Education, Agustín Serrano de Haro, in his book of historical readings for girls, entitled Garlands of History.

The study of the category of motherhood leads us to understand the method employed in school textbooks in order to construct a particular feminine gender identity. Although it appears to belong to the exclusive field of Women's Studies, I believe that the analysis of the representation of the universe of motherhood in textbooks directs us to the discovery of a manipulation or, to be more precise, it reveals the awakening, orientation, or education of certain emotions, mainly patriotic and Catholic. When we speak of motherhood we enter the world of girls' childhood. Girls and women (mothers) share such world. The childhood (and youth) of girls, unlike that of the boys' is shared with the world of adult women.

It is also to underline the importance of emotions as key factors to be analysed in the study of social, historical, political, and educational events and actions. The contents, language, and style of school textbooks under the Franco regime primarily aim to model particular feelings and emotions, rather than develop the children's intellect.

The schoolbooks which have been analysed present and project a specific image of boys and girls, and of their lives, how they should behave, how they are expected to behave, how everyone would like them to behave, always from the point of view of the adult, the book's author, who follows the instructions of those who authorise his work. My analysis of the presentation and representation of the universe of motherhood reveals an attitude towards childhood which can be summarised by four points:

1. In the first place, childhood gains importance and its beauty is highlighted. It constitutes a source of immense happiness; it is the continuation of the family, on the one hand, and the growth of the fatherland, on the other. This 'beautiful' and 'tender' childhood is a period for learning to do one's duty: serving the fatherland. From this perspective, childhood is essential for the future. These ideas are reflected and translated into

esperanza de la Patria. En vuestro corazón lleváis su grandeza o su ruina, como llevan las flores, bajo la delicada envoltura de los pétalos, las semillas de las que brotarán los frutos azucarados y olorosos. Clavad bien en vuestras entrañas el ansia incontenible de hacer a España cada día mejor. Porque ESPAÑA SERA LO QUE VOSOTRAS HAGAIS DE ELLA". 
actions of the State which aim to protect motherhood and childhood. The schoolbooks themselves reflect an attitude of admiration towards this period of life and the happiness which it produces. José Gutiérrez Abascal, in a text entitled 'Children', curiously added to the chapter devoted to a selection of readings on Nature in the reading book of Ezequiel Solana, entitled Recitaciones Escolares, tells them (and us) that the child surpasses all the wonders of creation:

Because it is the union of everything", because "it is like the flower, the butterfly, and the stars... Children are, undoubtedly, the most beautiful beings of all creation... Life would be very empty and sad without childhood. A home without them is like a hive without bees, like a garden without flowers. Someone who has never opened the white curtain which hides a crib, and looked upon a child, blood of one's blood, heir to one's name, continuator of one's life, does not know happiness, nor hope, nor the acceptance of responsibility. ${ }^{11}$

2. Secondly, childhood is clearly divided into two different phases, depending on sex (and social class). Can we speak of a common, universal form of childhood; or rather must we speak of several different childhoods, which depend on exogenous factors, endogenous factors, or both?

The childhood of girls is dominated and absorbed by their obligatory future role as mothers. Motherhood, and everything which this concept implied in this period, colours all aspects of family, social, and school life. Preparation for motherhood begins during childhood and continues throughout youth and adult life. It is conceived as a natural, exclusive, and obligatory process, through which girls fulfil their duty to the fatherland. Inspector Álvarez de Cánovas makes this clear in the chapter entitled 'Mummy's dolls', in the first book of the collection Mari-Sol (Little girl):

11 E. SOLANA, Trozos escogidos. Recitaciones escolares. La Familia. La Escuela, La Patria. La humanidad. El Arte. La Naturaleza. Dios. Madrid, Escuela Española, 1944, pp. 168-169. Original quote reads: "porque es el conjunto de todo" porque "tiene algo de flor, de mariposa y de estrella. [...] Los niños son, indudablemente, lo más hermoso de la creación. [...] La vida sería muy árida y muy triste sin la niñez. Un hogar sin ellos es como colmena sin abejas, como un jardín sin flores. El que no ha descorrido la cortina blanca que oculta una cuna, para mirar dormir al niño, sangre de su sangre, heredero de su nombre, continuador de su vida, no sabe lo que es dicha, ni formar esperanzas ni aceptar responsabilidades". 
...Mari-Sol's mummy always had a passion for dolls and never let go of them until the Lord gave her this little doll of flesh and blood called Mari-Sol, more beautiful than all the dolls in the world. ${ }^{12}$

The childhood of boys does not include either a theoretical or practical conception of fatherhood as a patriotic duty. However, with regard to girls, the Public Instruction Law of 9 September 1857, known as the Moyano Law is extremely explicit in this sense:

In the elementary and superior education of girls, the following studies included in the sixth paragraph of art. 2 ['Brief introduction to Agriculture, Industry, and Commerce'] and the first and third of art. 4 ['Principles of Geometry, Linear Drawing, and surveying' and 'General introduction to Physics and Natural History'] will be omitted and replaced by: First. Work appropriate for the female sex. Second. Principles of Drawing applied to this work. Third. Brief introduction to Domestic Hygiene. ${ }^{13}$

3. In the third place, the childhood displayed in schoolbooks is the childhood of Spanish boys and girls. The emphasis is always placed, in accordance with the dominant ideology, on everything that is Spanish, as opposed to what is not Spanish or anti-Spanish. Spanish childhood is a different childhood, a better childhood. Ezequiel Solana himself, in a poem entitled 'To Spanish Children', tells them:

\author{
Children, fortunate souls \\ Who have been born Spanish; \\ Those who one day will give \\ Honour and glory to the fatherland;
}

Do not reject your blood,

If blood be named,

12 J. Álvarez de Cánovas, Mari-Sol (pequeñita). Libro de lectura para niñas. Madrid, Magisterio Español, 1942, p. 64. Original quote reads: “[...] la mamá de Mari-Sol tuvo siempre pasión por las muñecas y no las dejó de la mano hasta que el Señor le dió (sic) esta muñequilla de carne y hueso que es Mari-Sol, más bonita que todas las muñecas del mundo".

13 Article 5 of the Moyano Law: "En las enseñanzas elemental y superior de las niñas se omitirán los estudios de que tratan el párrafo sexto del art ${ }^{\circ} 2^{\circ}$ ["Breves nociones de Agricultura, Industria y Comercio"] y los párrafos primero y tercero del art $4^{o}$ ["Principios de Geometría, de Dibujo lineal y de Agrimensura" y "Nociones generales de Física y de Historia Natural"], reemplazándose con: Primero. Labores propias del Sexo. Segundo. Elementos de Dibujo aplicado a las mismas labores. Tercero. Ligeras nociones de Higiene doméstica". 
Of those brave leaders

Who shook the world. ${ }^{14}$

4. In the fourth place, the heart and soul of childhood, but not the mind, seems to be the target of the schoolbooks. These texts resort to the exaltation of emotions and the appeal to feelings, but not to explanations with rational arguments in order to persuade and guide the children. The emotion of love is everywhere; more than understanding and knowing, what is asked of children is to love without questioning. Patriotism, nationalism, and Catholicism are fused together in one set of feelings and emotions, and childhood is presented as a gift wrapped in the cellophane of love and happiness. The publishing house Edelvives in his third book of Graded Readings, is very explicit:

GOD and FATHERLAND are two loves you must hammer into your heart. GOD, FATHERLAND, forever, forever. Forever GOD and FATHERLAND. ${ }^{15}$

The childhood which emerges from the schoolbooks is a childhood conveniently reevaluated, idealised, Spanish, differentiated with regard to sex, and which emphasises emotions over reason and intelligence. Childhood is necessary, so boys and girls must be taught to love and protect it. At the same time, childhood is responsible of loving and protecting Spain. This process of indoctrination is initiated above all with girls.

\section{The Re-valuation of Childhood}

It has been rightly said that 'the present century is the century of childhood'

These words come from a speech by José A. Palanca on children's health. They are more relevant than one might consider at first glance. Keeping

14 E. Solana, Trozos escogidos, cit., pp. 66-67. Original quote reads: "Niños, los afortunados que habéis nacido españoles; los que a la patria algún día daréis prez y altos honores; no reneguéis de la sangre puesto que sangre se nombre, de aquellos bravos caudillos que hicieron temblar el orbe".

15 Edelvives, Lecturas graduadas. Libro tercero, Zaragoza, Luis Vives, 1952, p. 6. Capitals come from the original text. Original quote reads: "DIOS y PATRIA son dos amores que debes clavar en el corazón. DIOS, PATRIA, por siempre, por siempre. Siempre DIOS y ESPANA." 
in mind the population policies and campaigns carried out in order to encourage natality and to combat child mortality, we discover that, in effect, the focus of all the new regime's social policies was the child (his birth and the avoidance of his death). Each woman was helped, encouraged, and trained as a woman-mother, in other words, as a means to bring children into the world and rear them, not as a woman-person. The education of girls and of women was the same. The mission of a woman's life, inspired by motherhood, began during childhood (of the girls).

Child mortality as a result of immaturity has increased in the period 1903-1942. This demonstrates the necessity of strengthening the institutions for pregnancy control and assistance for mothers during labour and for newborn children. ${ }^{16}$

This approach strengthens the idea of the instrumental use of maternity with political, ideological, and religious objectives. Numerous and diverse strategies were implemented. Beatriz Eceheverri Dávila divides them into two groups: the increase in the coverage of maternity insurance, along with the establishment of a network of maternal and paediatric medical centres, on the one hand; and the systematic dissemination of norms for hygiene and childrearing, on the other. ${ }^{17}$

Formal and informal education took part in the projects which we could designate as 'pro-healthy and efficient maternity' and 'anti-child mortality' - as part of the second strategy mentioned - in a singular and curious manner: firstly, transmitting, inculcating, and manipulating the maternal-patriotic-religious aspect (emotional dimension); secondly, disseminating the more practical knowledge related to childrearing, housekeeping, and care of the husband (informative dimension), as a constitutive part of maternity; and thirdly, inculcating the patriotic, religious, and moral sentiments dictated by the new regime (ideological dimension), also as an educational task included in the concept of maternity. The aspects related to the first phase of maternity: sex, pregnancy, birth, and post-birth were ignored in the schoolbooks, which did not include images of pregnant women, nor any mention of them in the texts.

16 Ivi, p. 32. Original quote reads: "La mortalidad infantil por inmaturidad ha aumentado en el periodo 1903-1942. Lo que nos afirma en la necesidad de los aumentos de las instituciones de control del embarazo y de asistencia al parto y al recién nacido".

17 B. Echeverri Dávila, La capacitación de las madres. El ejemplo de España en la posguerra: 1940-1950, en <http://www.adeh.org/agenda/menorca2003/Echeverri. pdf>,p. 1. 
This is undoubtedly one of the key theoretical points of the study: the way in which the national-Catholic state treats motherhood, when its real objective is children and Spain's demographic potential. Within this treatment of motherhood, the sentiment of mother-child love as a natural element is integrated, for reasons of political-ideological-religious convenience. However, we know that the evolution of maternal attitudes throughout history demonstrates that interest in and dedications towards the child are not always manifested. Neither has tenderness existed always or in the same manner. ${ }^{18}$

The love which the State dictates must guide the intensive care of the child by the mother is socially and culturally constructed and is more complex than what the schoolbooks transmit to the girls.

In his book What children die of in Spain, Doctor Juan Bosch Marín, head of the Child Care Section of the General Directorate of Health, eloquently expresses the need for children to be born:

What does the Fatherland lose when a child dies? Not only intelligence, a heart, arms, a soldier [...] Who knows if a saint, a discoverer, a great politician [...]. A loss for the Nation. A loss for all is that of children who do not die because they were never born. ${ }^{19}$

This importance given to the child in the post-war period also has its initial impulse, according to José Antonio Cieza García, in the beginning of the twentieth century. The emergence of the "genesis and consolidation of a new image of childhood" is the result of the social changes at the turn of the century. Alongside the struggle against mortality and the campaign to increase natality, there also emerged "a theoretical concern for the respect and protection owed to children". These interests centred on "the flourishing of a new image of the family in which a new structure and new sentiments also provided a new role for children at the heart of the industrialised societies of the nineteenth and twentieth centuries". ${ }^{20}$

18 E. Badinter, ¿Existe el amor maternal? Barcelona, Ediciones Paidós Ibérica, 1984, p.14.

19 J. Bosch Marín, De qué mueren los niños de España. Publicaciones 'Al servicio de España y del niño español', n 146, 1950, p. 3. Original quote reads: “¿Qué pierde la Patria cuando muere un niño? No tan sólo una inteligencia, un corazón, unos brazos, un soldado .... iQuién sabe si un santo, un descubridor, un gran político(...) Pérdida para la Nación. Pérdida para todos es la de los niños que no mueren porque no nacieron".

20 J. A. Cieza García, "Mentalidad y educación en España durante el primer tercio del siglo XX”, en Historia de la Educación, no 5 (enero-diciembre), 1986, pp. 299-316, 
These new sentiments include the unquestionable and unconditional love of parents towards their children and vice versa, but above all, of the mother towards her children and of the children towards their mother. Francoism recovered, exploited, and manipulated this emotional configuration, also encouraged by the Church, which made the parents responsible not only for the mission of procreation within marriage, but also of the care, love, and education of their children. In theory, what was prescribed was a balance or, in Jordi Roca's words, a "mixture of alternative doses of love and severity" in the education of children. In practice, however, there appears to have been an "imbalance which clearly favoured" severity, in which punishment was included. Not surprisingly, the civil code of 1889 , which remained valid during the post-war period, established in its article 171 that "the courts may deprive parents of their parental rights and authority, or suspend it, if they treat their children with excessive harshness". ${ }^{21}$

\section{The Heart and Soul of Children}

Authors employ endlessly the technique of touching the emotional structure of the students in order to involve them emotionally, to make it penetrate the complex and abstract concepts of patriotism and Catholicism wrapped in maternal love, so as to give them some meaning and validity. I focus on the feelings of love, pride, and shame ${ }^{22}$ that sprout from the messages, language and iconography present in the manuals. Ascarza, for example, to explain the importance of housework that girls begin to do since their childhood, he says without hesitation, en su libro La niña instruida:

p. 302. Italics belong to the author. We are dealing with the feelings of privacy, intimacy, and love present in the family.

21 J. Roca i Girona, De la pureza a la maternidad. La construcción del género femenino en la postguerra española. Madrid, MEC, 1996, p. 279.

22 One of the main issues of my theoretical frame is the idea of the pride-shame balance Explained by T. Scheff, in Emotions and Identity, en C. Calhoun (ed.), Social Theory and the Politics of Identity, Oxford, Blackwell, 1994, pp. 277-303. 
On you, girls, depends that one day people may say that you are good mothers and excellent governing women, which is the highest compliment that it can be said to a woman. ${ }^{23}$

The privileged place of emotions is pointed out by Agustín Serrano de Haro in his prologue to the famous schoolbook; I am Spanish, when he warns teachers that what he wants is children to,

Begin to hear the exemplary names and heroic deeds, that the things of God and of Spain, as if they were blessed salt in the yeast germ of their consciences. But not just to "know". Not everything has to be to know, is also important to feel! [...] What matters is that the lesson penetrates deeply and leaves their guts shaking with emotion. ${ }^{24}$

Similarly, in the prologue to the first edition of the reading book, Interesting readings, belonging to the Inspector José Herrero Pérez, we are clearly reported that the purpose is,

The inculcation of three great loves. Love of God (..), the love of country (...), the love of Progress (...)". Indeed, is not merely to "provide a wealth of useful knowledge $(\ldots)$ but to infiltrate those great ideals generating the most altruistic and noble feelings $(\ldots) .^{25}$

The Inspector Adolfo Maíllo, in his Commented Reading Book, also entitled Camino (Path), insists on the same issues in the first chapter, "Mis

23 V. F. ASCARZA, La niña instruida. Higiene y economía. Madrid, Magisterio Español, 1939, p. 6. Original quote reads: "De vosotras, niñas, depende que un día se diga que sois buenas madres y excelentes mujeres de gobierno, que es el mayor elogio que se puede hacer de una mujer".

24 A. Serrano de Haro, Yo soy español. El libro del primer grado de Historia, Madrid, Escuela Española, Hijos de Ezequiel Solana, 1957, pp. 5-6. Original quote reads: "empiecen a oír los nombres ejemplares y las gestas heroicas; que las cosas de Dios $y$ de España entren, como sal de bendición, en la levadura germinal de sus conciencias. Mas no precisamente para que "sepan". Todo no ha de consistir en saber; ¡también tiene su importancia el sentir! [...] Lo que importa es que la lección cale hasta lo hondo y deje las entrañas temblando de emoción".

25 J. Herrero Pérez, Lecturas interesantes. (Sobre la Naturaleza, la Patria y el Progreso), Zaragoza, La Educación, Librería y Material para Escuelas, 1940?, p. 5. Original quote reads: "la inculcación de tres grandes amores. El amor a Dios (...); el amor a la Patria (...); el amor al Progreso (...)". Efectivamente, pretende no sólo "proporcionar un cúmulo de conocimientos útiles (...) sino infiltrar aquellos grandes ideales generadores de los más altruistas y nobles sentimientos (...)”. 
amores"' ('My loves'): the love of God, love of parents, and love of the fatherland. ${ }^{26}$

The appeal to the education of the feelings to achieve an integral education represents a qualitative leap in respect and understanding of children. But during the Franco years the goal was to mould the feelings and emotions of children, through lies, confusion, ambiguity, lack of information and training, as well as unrealistic expectations about motherhood. The exaltation of motherhood through its metaphorically fusion with the Homeland serves the dual purpose of raising the social status of the theoretical concept and the real phenomenon of motherhood, on the one hand, and of approaching and filling of familiar feelings the concept of fatherland. This is to create consistency between the message released to the masses through other means of communication and teaching in school.

Text analysis studies have shown that familiarity with the issues increases the sensitivity of the reader to the text that reads and contributes to the understanding of the structure. Background knowledge is essential for the understanding of a given text. Given the degree of difficulty of the language used in most textbooks for children, I am inclined to think that on the one hand, such complexity, besides constituting a characteristic of the time, is intended to camouflage the contradictions, ambiguities and absence of reasoning in the content, and to seem more serious.

However, on the other hand, explicit and hidden messages are consistent and reproduce the experience outside of school. Children must learn that the fate of women is unquestionable motherhood, conceived in a single form, that is through maternity that women contribute to the country and, moreover, that it is a guaranteed source of happiness for both, boys and girls, future family men and women. His parents therefore are complying with their duty, and they must emulate them.

Children learn to feel respect and admiration for their parents and to know their fate forced and imposed from above. Childhood has its path traced. Their mission is the same one: to serve the country, but in a different way. While boys do not contribute trough fatherhood, girls only contribute trough motherhood.

The mother figure rises everywhere, awakening love, affection and devotion. I have found numerous references to the different mothers Spanish children have, especially the figure of the mother country, of whom

26 A. Málllo, Camino. Libro de lectura comentada. Barcelona, Editorial Miguel A. Salvatella, 1942, pp. 9-13. 
Dalmau Carles says, in his reading books entitled El primer manuscrito (The first manuscript):

The fatherland has to be our strongest love: true love of loves. She shelters us, educates us, keeps us and protects us: she is also our Mother, and as our mother in the flesh, we should revere, honour and love her $[\ldots] .^{27}$

We also perceive that the main covers of the manual, in its various editions, are dedicated to the tender scene of a woman reading with children, with affectionate, maternal gesture.

But to the mother of God, "the Blessed Virgin, who loves us as much as our mother on earth and even more," the natural mother, devotes Antonio Arnao a poem entitled, 'Lo más bello' ('The most beautiful'), in the first book of the Graded Readings of the publishing house Edelvives, which reads as follows:

But nothing is so beautiful, nothing inspires. Emotion so sublime As the mother when at the child looks And on his sleeping face a kiss prints. ${ }^{28}$

In conclusion we can affirm that childhood is subject to state interests, is not a free childhood. I think a impossible mission is projected on it; a mission that goes beyond their means and that is unfair with their nature. Girls start their motherhood training from their earliest childhood, becoming the unique phenomenon of their lives and the only activity in which they can be active. They are denied the development of any other personal dimension. ${ }^{29}$ Control, pressure, manipulation and intervention of the new regime and the Church on motherhood respond to concept of biopolitics described by Foucalt. Such power monopolizes and dominates the whole

27 J. Dalmau, Método completo de lectura. El primer manuscrito. Gerona-Madrid, Dalmau Carles Editores, 1942, p. 7. Original quote reads: "La Patria ha de ser nuestro más firme amor: el verdadero amor de los amores. Ella nos cobija, nos educa, nos guarda y nos defiende: ella es también nuestra Madre, y como a nuestra madre carnal, debemos reverenciarla, honrarla y quererla".

28 Edelvives, Lecturas graduadas. Libro primero. Zaragoza, Luis Vives, 1949, p. 175. Original quote reads: "Pero nada es tan bello, nada inspira/Emoción tan sublime/Como la madre cuando al niño mira/Y en su dormida faz un beso imprime".

29 We could refer to the exception of the activities carried out by the Feminine Section of the Extreme Right Wing Party (Falange), although with some reservations. 
human being as a person, in this case, literally, the body and the soul of girls.

It is true that "the human body exists in and through a political system" and that each political power provides varying degrees of space to the individual. However, during the period that concerns us, political power sees women, since childhood, a force or source of production in a single direction and in a unique way, and this is instilled in them since the early years of social, familiar, and school education. Women and men are forced to procreate. But man has other areas of activity allowed apart from paternity. The woman's body has a mission that does not concern his individual will. All her education and training is geared and designed to the proper exercise and performance of the required unquestionable role.

Feelings become the essential element that characterizes childhood, above thought. Education is reduced almost to the child's emotional orientation toward sources of love, pride and shame (also of hatred, fear and honour), without giving more space to reasoning, cognition, and understanding.

\section{Masculine Identity in School Textbooks During the Franco Regime}

All cultures have developed normative and prescriptive models of masculinity and femininity. These models vary enormously throughout different societies and historical periods, but in all of them the masculine figure seems to be endowed with greater prestige and social relevance, as well as the activities, conduct, and knowledge attributed to him, regardless of what they may be. Wherever the male hunts, fishes, and fights, these are considered to be most prestigious activities, but the same is true wherever the male weaves, cultivates, makes pottery, or watches over cattle herds. ${ }^{30}$

In all cultures, gender differences constitute the primary organising principle of the social order and, at the same time, of the subjects' psyche. Gender establishes the primary field of possibilities and exclusions

30 K. MILlET, Política sexual, Madrid, Cátedra, 1995. 
of social agents, the type of socialisation each will receive, the knowledge they will have access to and that which will be prohibited, licit or illicit behaviours, the emotions they may cultivate and display in public, and those which they must repress. Gender identities constitute, in short, the basic organising principle of the human order.

Group and class divisions are reflected in myths, creation narratives, rites of passage and initiation, oral traditions, literature, legal principles, institutionalised education, etc., which explain and justify basic inequalities. At the same time, such symbolic constructions provide consolation to the weak and deprived, as well as arguments for the exercise of authority to the powerful, which simultaneously conditions the psychological, emotional, and behavioural structure of each individual, depending on his or her gender and class.

It must firstly be noted that not only in the mass media, but even in scientific articles, the concept of "gender" tends to be applied almost exclusively to feminine issues, to the extent that the words "gender" and "woman" are erroneously and automatically associated. For us, gender will refer to the symbolic construction, as well as the individual and sociocultural assumption of sexuality. ${ }^{31}$

The traditional Western European culture (if we only limit our analysis to this historical-geographical area) is grounded upon the inequality of genders and sexes, which it views as a "natural" phenomenon", and this asymmetry is firmly legitimated in society through religion, politics, and culture, including various "scientific" discourses embodied in theories, social practices, and institutions, such as the principal socialising agency of modernity: the school. This educational institution implemented policies of sexual and gender differentiation, which aimed to establish enduring identities based on the inequality of attributes, properties, access to material resources and positions of prestige and power, rights and duties, freedoms and obligations, beyond the strictly biological differences determined by pregnancy, maternity, and breastfeeding. These values and the "knowledge" associated with them were the objective of a specific policy of differentiation and inequality embodied in a more or less explicit, more or less hidden school curriculum, depending on the historical period, an issue which has been explored by an extensive and diverse field of research.

31 For more information on the history of the concep of gender, see A. García-Mina Freire, Desarrollo del género en la feminidad y la masculinidad, Madrid, Narcea, 2003. 
The majority of these studies focus on the form, content, and procedures for the discrimination and subordination of women under masculine domination. Fewer studies have devoted themselves to the contents and procedures for the construction of a masculine identity which, although its ultimate aim has been the formation of a dominant social subject, constitutes a process of socialisation grounded upon violence and restrictions against males themselves, perhaps equivalent to that suffered by women. The ultimate prize of a dominant position (of some men over the majority of men and women; and of men in general over women, with the exception of those of the upper social class) can only be achieved by paying the price of the deprivations, prohibitions, humiliations and violent aggressions employed, assumed, and internalised by boys and young men.

During the Franco regime and, above all, during its first two decades of power, there was a "restoration" and an apogee of what we could call "traditional" social and political values: authority, order, hierarchy, honour, patriotism, Catholicism, militarism, dogmatism, fanaticism; exaltation of heroism and "heroes"; contempt for, intolerance towards, and persecution of dissidents and all opinions and beliefs which differed from the official ideology, rejection of pluralism and democracy, etc.

Hence, these values were represented by and belonged almost exclusively to men. The natural capacities of women, as is well known, were reduced to their "natural" biological functions: reproduction and childrearing. As a schoolbook of the period affirmed:

The Spanish authority has always aimed to be the first and greatest amongst his men, and has possessed the highest degree of the characteristic virtues of his race: faith, abnegation, austerity, exemplarity, heroism, the spirit of service and sacrifice, determination, initiative, equanimity, foresight (...) Such qualities of the Spanish people have made possible the birth of great leaders in all periods of history. ${ }^{32}$

One must take into account that as a result of the Civil War and the spirit of the "Holy War" against Communism, atheism, and liberalism, the values,

32 A. Sospedra, Formación del espiritu nacional. Valores encarnados y defendidos por España a lo largo de la historia, Madrid, Ediciones de la Delegación Nacional del Frente de Juventudes, 1954, p. 28. Original quote reads: "El Mando español ha tenido que ser siempre el primero y el mejor entre sus hombres y el que ha poseído en más alto grado las virtudes propias de la raza: la fe, la abnegación, la austeridad, la ejemplaridad, el heroísmo, el espíritu de servicio y sacrificio, la decisión, la iniciativa, la ecuanimidad, la clarividencia (...) Tales características del pueblo español han dado lugar al nacimiento de Caudillos en todas las épocas de la historia”. 
beliefs, and attitudes of militarism are perhaps overrepresented, and there is an exaggerated exaltation of the most orthodox version of the Catholic dogma.

But, bearing in mind this precaution, the conceptual and moral universe of Francoism reflects the dominant social values of Spain from the $19^{\text {th }}$ century up until the second half of the $20^{\text {th }}$, with regard to the configuration of the masculine and feminine character, each one with its proper attributes, knowledge, social abilities and professional qualifications, and its potential spheres of action clearly delimited and differentiated.

\section{The Restoration of Traditional Values in the Franco Regime}

During Francoism, which, as we have pointed out, was immersed in what we could call "traditional Spanish society", boys were educated to act in the public sphere and girls in the private and family one, as many studies have previously shown.

However, the hegemonic masculine model could only become a reality for a reduced group of men: young, Spanish-speaking, Catholic, educated, urban, liberal professionals, economically solvent, and in positions of leadership and power.

The real life situation of the vast majority of men (and, of course, women) had very little in common with that archetype: in the middle of the 20th century, the majority of Spanish society was rural, the rate of illiteracy was very high, large sectors of the population did not have Spanish as their mother tongue, poverty was widespread, work conditions in many cases resembled feudalism, etc. (without taking into account the terrible consequences of the Civil War). For this reason, most men could only view such values as something very distant from their own lives, characterised by subordination, exploitation and personal dependence, although they did function as a desirable ideal which one could aim to achieve.

Such a humiliating situation for men, in contrast with the aspired ideal of superiority, was only bearable if there was someone further below them, in front of whom they could occupy a dominant position in the framework of their social fantasy and vent their own shameful frustrations and fears. 
To be a king was, in other times, a universal dream, not only of the politicians, but also of the fathers who ruled over their children, of the husbands who treated their wives as servants (...) In real life, the vast majority of human beings has been submissive during the last five thousand years, humbly bowing before authority, except during some brief outbursts of protest, sacrificing themselves so that a small minority could live in luxury. They could have turned into submissive animals, if it were not because the majority of them found someone else to tyrannize, someone weaker or younger. Inequality was accepted for such a long time because those who suffered the bullies in turn found victims to intimidate. The powerful leader was admired because he embodied the dreams of authority which humble people secretly aspired to and tried to turn into reality in their private life. ${ }^{33}$

In this "traditional society embodied by Francoism, boys were educated for war, honour, to exercise violence, withstand pain, become accustomed to intentional deaths, to disdain the weak and love the strong, to (blindly) obey authority, to respect and make others respect the symbols of power.

The schoolbooks, instruments of great importance in the construction of mentalities and social imagery in contemporary societies, display with great clarity during this period (since there was no need to conceal the curriculum) all of these principles and premises.

(...) The heroism of the Numantines adopted a new and terrifying form. They set fire to the houses, burnt down the furnishings and possessions and killed each other, before surrendering to the Romans (...) When the Roman troops entered the city, they only found ruins, ashes, and corpses, precious proof of the stoic valour and love of independence of the noble Spanish race, which prefers death to losing liberty and honour. The glorious remains of Numancia are an imperishable monument to the heroism and courage of the Spanish people. ${ }^{34}$

Even more heroic - added Isidoro - was the feat of sublieutenant Fernando de Illescas, more than four centuries ago. In Spain, the glorious Catholic Kings ruled, and the Great Captain, Gonzalo de Córdoba, conquered Italian lands to expand our Empire. Then the battle of the Garellano river took place, which was harsh but victorious for

33 T. Zeldin, Historia intima de la humanidad, Madrid, Alianza, 1996, p. 138.

34 A. Maíllo, Camino. Libro de lectura comentada, cit., p. 23. Original quote reads: “(...) El heroísmo de los numantinos adoptó una forma nueva y atroz. Incendiaron las casas, quemaron los ajuares y riquezas y se dieron muerte unos a otros, antes que entregarse a los romanos (...) Cuando entraron en la ciudad las tropas romanas, sólo hallaron en ella ruinas, cenizas y cadáveres, muestras preciadas del estoico valor y el amor a la independencia de la noble raza española, que prefiere la muerte a perder la libertad y el honor. Los escombros y restos gloriosos de $\mathrm{Nu}$ mancia son un monumento imperecedero al heroísmo y bravura de las gentes de España". 
our troops. Sublieutenant Illescas carried one of the flags, when a cannonball tore off one of his hands. Another man, in his situation, would have nursed his wound.

- Naturally.

- Well no, sir; he grasped it with his other hand without worrying about the blood he was losing, until another bullet tore off his left hand as well.

- And then?

- Then he picked it up with his bloody stumps, and the flag continued to display in all its splendour the glory of its colours and proclaiming the greatness of those children of Imperial Spain (...). ${ }^{35}$

OATH TO THE FLAG. In the Army as well as the Navy, recruits swear fidelity to it until death, with God as their witness (...). It is shameful for the enemy to seize just one of our flags (...). It is, on the other hand, a great victory to seize the enemy's flags. Hence, he who forsakes his own country and rejects his flag, he who goes up in arms against her, is a perjurer and a traitor, and deserves neither the protection of the State nor the love of the Motherland. ${ }^{36}$

YOUTHFUL HEROISM. THE ARROWS OF THE "BALEARES". It happened one night in the spring of the year 1938. Spain, illuminated by faith, fought at sea an

35 A. Martínez de La Torre y López de Robles, ;Lánzate al cielo...!. Método de iniciación político social por aplicación de la lectura, [Madrid], Delegación Nacional del Frente de Juventudes, 1950, p. 98. Original quote reads: "Pues más heroico aún - añadió Isidoro- fue la hazaña del alférez Fernando de Illescas, hace ya más de cuatro siglos. Mandaban en España los gloriosos Reyes Católicos, y el Gran Capitán, don Gonzalo de Córdoba, conquistaba en Italia tierras para ensanchar nuestro Imperio. Ocurrió entonces la batalla del río Garellano, dura, pero victoriosa para nuestras armas. El alférez Illescas llevaba en ella una de las banderas, cuando una bala de cañón le arrebató una mano. Otro, en su caso, se hubiera ocupado de curarse.-Naturalmente. - Pues no, señor; la cogió con la otra mano sin preocuparse de la sangre que perdia, hasta que otra bala le arrancó también la mano izquierda. - ¿Yentonces? - Entonces la cogió con los muñones sangrientos, y la bandera siguió agitando al aire la gloria de sus colores y pregonando la grandeza de aquellos hijos de la España Imperial (...)”.

36 Símbolos de España (1960). Libro escolar de lectura, Madrid, Editorial Magisterio Español, p. 65. Original quote reads: "JURA DE LA BANDERA. Tanto en el Ejército como en la Marina, los reclutas le prometen fidelidad hasta la muerte, poniendo por testigo a Dios. (...) Es vergonzoso que el enemigo nos arrebate una sola de nuestras banderas (...) Es, en cambio, una gran victoria el apoderarse de las banderas del enemigo. Así, el que pasa a otro país y reniega de su bandera, el que se levanta en armas contra ella, es un perjuro y un traidor, y no merece que el Estado le proteja ni que la Madre Patria le ame". 
on land. The "Baleares" protected the Mediterranean from some merchant ships. Suddenly, an enemy squadron appeared, very superior in number and strength. The battle then begun. The cannons whistled and the ships were set on fire. The "Baleares" began to sink little by little. It had been torpedoed and the sea slowly swallowed it. On the verge of collapse, the entire crew formed on the deck and with their arms spread out, sung their last "Cara al Sol" (Facing the Sun). Nine young and brave arrows serenely cried out: I will join my fellow soldiers, who keep guard next to the stars. They died with the rest, dreaming of a better Spain. Also as a child one can be a hero if the Fatherland demands it. ${ }^{37}$

THE DUTY OF THE SPANIARD. Spain is our fatherland. It is a great, beautiful, and glorious fatherland. It is great fortune to be born a Spaniard. But to be Spaniards imposes serious duties upon us. Spain was in the past the greatest power in the world. This is our mission. For this reason, it is crucial to study a lot and to work a lot. Spain must once again become great. And this must be achieved by the Spaniards who today are children. It depends on you whether the Fatherland is to become happy, wealthy, and powerful. What glory awaits when this is achieved! Let us make Spain great once again, as it was in the past.

This last reading is followed by another text entitled "The fearful mouse", which tells the story of a cowardly mouse, which is transformed by a fairy first into a cat, then into a dog, then into a lion...

But the fairy, fed up of seeing him so frightened, became angry and said: - Since your heart is that of a simple little mouse, you must become a mouse once again. And the poor mouse had to go back into his hole. ${ }^{38}$

37 Enciclopedia. Grado Medio, Madrid, Edit. Escuela Española, 1962?, p. 194. Original quote reads: "HEROÍSMO JUVENIL. LOS FLECHAS DEL <>. Era una noche de primavera del año 1938. España, encendida de fe, luchaba en el mar y en la tierra. El crucero <> protegía en el Mediterráneo unos buques mercantes. De improviso apareció la escuadra enemiga, muy superior en número y fuerza. Se entabló la batalla. Silbaron los cañones y los barcos se incendiaban. El crucero se inclinaba poco a poco. Había sido torpedeado y el mar le tragaba lentamente. A punto de hundirse, toda la tripulación formó en cubierta, y con el brazo extendido entonaron su último Cara al Sol. Nueve Flechas jóvenes y valientes pronunciaban con serenidad: Formaré junto a mis compañeros, que hacen guardia junto a los luceros. Murieron con los demás, pensando en la España mejor. También siendo niño se puede ser héroe si la Patria lo exige".

38 P. Ruiz, Compendio de lectura. Primer libro, Barcelona, Seix y Barral, 1940, pp. 11-13. Original quote reads: "Pero el hada, cansada ya de verle tan pusilánime, se enfureció y le dijo:- Puesto que tu corazón es el de un simple ratoncillo-gritó-, conviértete otra vez en ratón. Y el pobre ratón tuvo que volver otra vez a su agujero". 
This reading is evidently the flip side of the previous one, and both of them together aim to make clear that the real men will make Spain great and powerful, while the fearful ones will live in a hole. Such readings are only two examples of hundreds of similar texts.

\section{The Political Programme of Masculine Identity}

The clearest evidence against the supposed "natural" basis for masculine violence is, on the one hand, the need for constant repetition, throughout all the years of schooling, of these models of "manly" values and actions, which demonstrates that it is in fact a political programme of indoctrination, as opposed to the supposedly "natural" and "essential" character of these masculine attributes.

On the other hand, the great intrinsic difficulty in transforming boys into violent and authoritarian subjects is exposed by the similarly constant need to associate the desired actions to basic emotions and feelings, such as paternal love, fear, and hatred. The identification of the fatherland with the mother, of national honour with the honour of the mother, of the political opponent with the enemy and the murderer who wants to destroy us, of the "heroic" and brave conduct as the essence of masculinity, of honour as a vital aspect of personal dignity, constitute the most visible signs of the problematic and complex political construction of masculine identity. As Pierre Bourdieu points out:

In the same manner as the tendencies towards submission, those which aim to vindicate and exercise domination are not inscribed in nature, but must be constructed through a prolonged process of socialisation, in other words (...) of active differentiation in relation to the opposite sex. (...) The masculine privilege is also a trap and finds its counterweight in the permanent tension and contention, sometimes to an absurd degree, which is imposed on every man by the duty to affirm his virility in any circumstance. ${ }^{39}$

In many school readings, it is the mother herself (the primary figure with which every individual, man or woman, identifies) who promotes and consents the sacrifice of her male children for the fatherland, for honour,

39 P. BOURDIEU, La dominación masculina, Barcelona, Anagrama, 2000, p. 67. 
or for the glory and greatness obtained in the battlefield. In other texts, there are also references to the figure of the father or the grandfather, all of which aim to link a contingent masculine identity to strong emotional bonds.

MOTHERS. Yesterday I saw the victory which will make us invincible. I saw in the white room of the whitest hospitala mother which stood by her dead sons. She prayed and she did not cry... We must triumph! What a victory of screams and sobs lay beneath those clenched ivory lips! One can understand the children that die in this manner when one sees mothers who feel it thus. ${ }^{40}$

THE SOLDIER MARCHED TO WAR... The soldier marched to war, proud, happy, jovial, and with the faith of a crusader said to his mother, embraced, at the threshold of the gate:- If I return, dear mother, I shall return triumphant; Yet... if eternal is my parting, I gave my life for Spain, which is the highest duty!"

TO THE GRANDSON WHO GOES TO WAR. My child, I am old now and when you return, I do not know if you will find me. That is why I would like you to listen to a few words (...) You lost your mother. I know you loved her with all your soul and that if they told you that someone offended her honour, you would give your life to defend it. I know that this you would do for your dead mother and this you will also do for your living mother. Because you have another mother who lives and someone wants to dishonour and endanger her: your mother, Spain! For her you will, if necessary, give the last drop of your blood'. ${ }^{41}$

\section{The Socio-Psychological Programme of Masculine Identity}

The reference to honour in numerous school readings is an element of great importance for masculine identity. "Honour" constitutes a prescriptive code of conduct which guarantees social and family recognition, the respect of the peer group, and individual self-esteem. On the other hand, "dishonour" leads to exclusion, contempt, isolation, and public as well as private humiliation.

40 E. SOLANA, La Patria española, Madrid, Editorial Escuela Española, 1962, p. 11.

41 The two last quotations belong to A. VILLAR, Simiente menuda. Libro de lectura para grados medios, Barcelona, Edit. Miguel A. Salvatella, 1945, pp. 97 and 110 respectively. 
And it is not merely a question of symbolic and emotional rewards or penalties, but also of access to or exclusion from material resources, since the enjoyment of cultural, material, and social goods is conditioned by the "recognition" which the family, the peer group, the state bureaucracy and institutions grant the subject.

It is not just a question of self-esteem or of social exclusion, but of material punishments and deprivations. And this is true in the best of cases: in more severe situations, it can directly signify death. All forms of obedience are ultimately grounded upon fear. The programmed and systematic cultivation and development of fear lies at the nucleus of traditional masculine socialisation.

The centrality of fear as a constitutive element of identity was also strengthened by the dogmas and the doctrines of the Catholic church, for whom individuals, if they do not fear God cannot fear the Devil either and, therefore, cannot be constituted as "moral subjects". The fear of God is the guiding principle of religious ideology, which is also manifested as (private) guilt and (public) shame.

In his monumental essay on the bases of social power, Elias Canetti employs the metaphor of the order. The action which is executed following an order is different to all others. It is perceived as something strange, external, which violates the will of the subject. We obey because we could not fight with any expectations of success. All orders are composed of two parts: the impulse and the sting.

When an order is obeyed, the sting is stuck in the flesh, and it will remain there, inalterable. The content of an order is preserved in the sting. The more orders that are obeyed, the more stings are stuck. The more stings, the greater the tension and the need for relief. The only way to remove a sting is to reproduce such an order in another individual, forcing him to obey in the same way one did so earlier, in a situation which must be almost identical to the previous one in which it was received.

The receptors of orders who are most affected by them are children. It seems like a miracle that they do not collapse under the burden of what they are ordered to do and survive the harassment of their educators. The fact that they later transmit all of this to their children, with no less cruelty, is as natural as chewing and eating. But what shall always surprise us is that the orders are maintained intact from the earliest infancy: they will appear as soon as the next generation offers its victims. ${ }^{42}$

42 E. CANETTI, Masa y poder, Barcelona, Círculo de Lectores, 2000, p. 453. 
Masculine identity is especially fragile. At a very early age, a boy must distance himself and reject identification with his mother, the main reference of shelter and protection. This is not the case for girls, who do not need to renounce identification with their mother in order to become individual subjects. The masculine identity is so fragile that it must permanently ensure and confirm the rejection of maternal identification.

In all or almost all cultures, boys must undergo public rituals in which they must exhibit their masculinity: rites of passage that examine their abilities and in which they demonstrate strength and valour. The recognition of adult men as well as that of the masculine peer group is the necessary guarantee for their self-recognition as males, an identity which will permanently be exposed to insecurity, and which will repeatedly demand new proofs and new exhibitions of strength, capacity, and violence.

The fear of feminine domination, the fear of contempt, ridicule, and humiliation in front of other males, and the fear of disobeying the order of being "tough" (in other words, generalised fear), constitute the foundation of masculine identity (and violence) in traditional society. The following text is an illustrative example of such values and actions (here "legitimated" by a context of war and in defence of the "superior interests" of the fatherland).

With guns on their shoulders and blankets, they both march together. The Requeté [soldier of the Carlist forces] is bearded and strong. The Falangist is almost a boy. They climb up a path towards the mountain, from whose peak they hear the constant sound of shrapnel. It smells like gunpowder and fatherland. (...)

REQUETÉ - If you get hit, who do you want me to tell?

FALANGIST - Nobody (looking at the sky). The chief will know immediately. And if you die?

REQUETÉ - Tell José María Hernandorena, 65 years old, regiment of Montejurra. He is my father.

FALANGIST - What if he's not there?

REQUETÉ - Tell José María Hernandorena, 15 years old, regiment of Montejurra. He is my son. (...)

REQUETÉ - Get down on the ground, for your mother's sake. (...) You're bleeding a lot. FALANGIST - The prize is for that gentleman of the enemy (The Requeté picks up the Falangist and carries him on his shoulder. The bullets whistle by the group of soldiers. The Requete falls on the ground with his partner). They've also wounded you. You're a brave lad. 


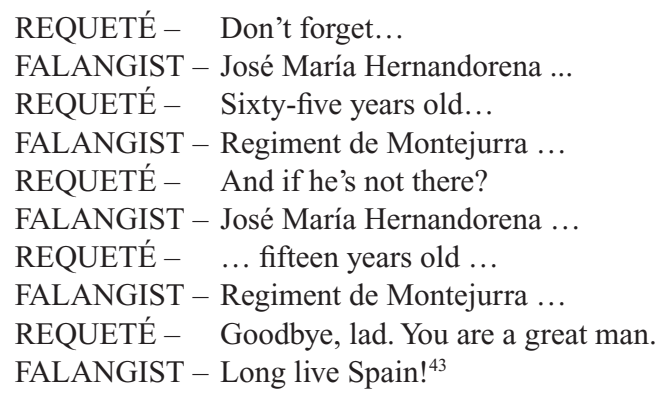

\section{The Role of Illustrations in the Construction of Gender Identities}

This last section of the essay pays special attention to the illustrations found in school textbooks. It also aims at inserting essential iconographic references in the study of History in order to approach a global understanding. We can not forget that pictures and images allow the historian to uncover aspects of the past which are not transmitted through written sources. They are richer sources in certain nuances and as visual sources; they have huge power in the transmission of ideas or messages. In this specific case study, images emerge as the perfect vehicle to convey feelings or emotions because they use didactic resources which are not possible to be used by written texts, and which are essential in the world of feelings such as, for example, gestures of the face or the body, actions, settings, etc.

In the complex world of emotions and the difficulty of addressing their study, this analysis focuses on those that help in process of identification of the human being or person, as a man or a woman, in order to understand the social relations established between both sexes.

The manuals consulted correspond to the disciplines which were mostly devoted to the transmission of behaviour and conducts: urbanity, civics, hygiene, religion, and particular texts used for teaching of reading. A first revision and observation of school textbooks leads us to realize that there are, both in nowadays' manuals and in those published during the Franco regime,

43 E. SOLANA, La Patria española, cit., pp. 14-16. 
certain emotions used for the purpose of encouraging readers, in this case young students, to identify those behaviours and conducts considered to be adequate and correspondent to their times and their sex.

We want to focus on powerful emotions which also appear more often than others. These are: joy and happiness, in this case joined to the feeling of pride; shame, and fear. The latter is represented in two different ways: firstly, the fear of punishment, taken to its extreme in religion textbooks, where punishment is represented by eternal fire; secondly, the fear of being rejected by others, of failure, of incompetence, of a lack of capacity to belong to a group. This fear, according to experts in developmental psychology of emotions, emerges at the age of five, in the middle childhood, when the child enters the social world. ${ }^{44}$

For this analysis we have selected various primary school textbooks precisely because they are characterized by the large number of images they contain and the variety of topics they address.

The emotion which appears the most is joy, frequently linked to love, and in particular to temperance and composure. These images convey the feeling of trust turns into the motor that pushes the wish for certain behaviour and conducts.

The number of illustrations showing a girl socializing with Nature has caught my attention. These images portray the feelings of pride, satisfaction and serenity. In a significant proportion of these images the girl, or woman, is represented smiling, with a clear facial expression of joy. There is no doubt that the purpose is also to transmit the idea of girls and women as naturally caring, tender, and sensitive, as well as to construct the believe that it is precisely that caring, tender, and sensitive character with Nature which produces the pleasurable sensation. Girls and women are therefore protective and vigilant of their land, their homeland or fatherland.

The boy is also frequently represented interacting with Nature, but in this case, the emotion used is considerably different. He appears in a very active, dynamic, stirring gesture that conveys the sense of movement and action. Sometimes, the physical action denotes a strong, almost violent effort. His body is in movement and his gesture shows agility. In several occasions the woman appears interacting with other people. In this case we can distinguish two different emotions, depending on who she is performing this interaction: either with someone younger, or with someone

44 M. Victoria del Barrio, Emociones infantiles. Evolución, evaluación y prevención. Madrid, Ediciones Pirámide, 2002, p. 148. 
older. When she interacts with someone younger, the feeling of protection arises. Her gestures, her body posture, the action itself portray positive emotions such as love and pride. Her body is usually represented in a flexible position, transmitting the sense of slow movement, as if her body was in a comfortable position and adapted. This comfortable physical posture is also reflected in her face. The illustration transmits the idea of a desired situation, socially accepted and valued.

However, when the relationship takes place with an adult, the emotions that are used to portray the correct behaviour are completely different. The body position varies substantially and changes from a flexible posture to a rigid and straight one. The facial expression is usually serious, with a surprise expression or with her eyes looking down showing submission and obedience; especially if the adult is a male. On the contrary, when the adult is a woman, a mother, a grandmother, or a teacher, the feelings of tenderness, affection, and sympathy reappear.

The boy, on the other hand, when represented interacting with an adult, it is mostly with another male. Almost always an expression of attention, of surprise, of curiosity, of receptiveness of what this adult has to tell or teach him, is shown in his face. These images portray the idea of a learning activity and attitude. When the interaction takes place between a male and a female, the latter is younger and the former shows a serious and rigid posture. Men are represented, in this case, transmitting responsibility and protection, depicted as teachers or priests, as guides; but they do not related to children with the same emotions of tenderness, affection or fondness as women do. The emotion of fear is used, as all negative emotions, to avoid unwanted behaviours and conducts, or to override behaviours which are considered as socially inappropriate. It is an emotion that deserves a wider study than what this brief paper allows, although certain considerations are worth mentioning. This emotion is particularly used in textbooks for the teaching of religion. The representation of the devil and flames of "hell" are used to instil the feeling of fear in children in these manuals. It is an emotion that does not usually appear alone, but as opposed or compared to an opposite or positive emotion. In the illustrations which follow, we can observe this argument. The devil often appears accompanying a sad, scared child, portraying the feelings of fear, anxiety, and sadness. At the same time and in contrast with such imaginary, in order to show the possibility of salvation, serenity, happiness and, joy come from the company of the angel. 
In the image that follows, we see a clear example of such emotions. The devil, represented by the red colour of fire, threatens and frightens the girl who has apparently misbehaved or not learned her lesson (shown by the donkey ears). But this emotion of sadness contrasts with the joy and serenity which the other girl transmits through the company of the angel. In addition, experts in iconography, argue that colours transmit different feelings and emotions. Orange seems to represent creativity and indecision. Green, on the contrary, represents mould, rust, and putrefaction.

Fear is directly related to sadness. It's an inconstant, fickle, uncontrollable, fierce, destructive sadness; refractory to any intervention of reason and of will. It involves doubt, hesitation, uncertainty, and danger from a coming evil. The conduct that is sought is precisely the one which will avoid that feeling of anguish and anxiety. Shame and guilt often appear in the same way as fear, compared with emotions that produce the appropriate and wanted behaviours. However, these emotions are not frequently found in school textbooks' illustrations. When showing shame, guilt, and pride it is a sign that the child has learned the consequences of his actions and is aware of their social acceptance.

The same think happens with anger. I have found very few images that portray this emotion. I show the only illustration of explicit violence between a girl and a boy. The boy is looking to the reader and the girl shows her back. The boy is therefore clearly showing his aggressiveness and his strength to the audience that is watching. The girl, on the contrary, hides her face as if ashamed of such improper behaviour, so distant from the usual tender, calm, caring images of girls. Normally, violent behaviour and the emotion of anger or aggressiveness are shown between men and Nature, transmitting the superiority of men (not women) and his possibility of domination.

\section{Conclusions}

It seems clear that illustrations are an adequate tool to convey not only knowledge contents but also emotions and feelings that students associate with certain behaviours. Furthermore, emotions are associated with different behaviours depending on the different sexes. This difference extends to the kind of behaviour which is socially accepted and recognized for each 
sex. Throughout this work I have tried to highlight the importance given to school textbooks' illustrations by the Franco regime in order to construct particular gender identities. The analysis of these images contributes significantly to the study of written texts in school manuals.

Both ecclesiastical and political powers were aware of the importance and power of iconic messages. They knew that through illustrations reality could be made more accessible and visible, and that they constituted a ideal vehicle to transmit, teach or impose established conducts and identities. Images offered the possibility of presenting ideologies, concepts, beliefs and opinions. Negative emotions are used as the annihilator of undesirable and harmful behaviours, as an intangible repressor. They appear less frequently than positive emotions and almost always accompanied by the latter. Joy, serenity, and pride seem to be the most popular emotions to obtain desired and socially accepted conduct.

Above all these emotions, there seems to emerge a dominant feeling: the feeling of being accepted by others, of knowing that one is accepted by the social community. It is a feeling of belonging to the group which correspond you. We would like to finish this paper by pointing to the need for further work in this line, to confirm these findings and to analyse emotions deeper.

\section{Bibliography}

G. Cámara Villar, Nacional-Catolicismo y Escuela. La socialización política del franquismo (1936-1951), Jaén, Hesperia, 1984.

E. Castillejo Cambra, Mito, legitimación y violencia simbólica en los manuales escolares de Historia del franquismo. Madrid, UNED Ediciones. Proyecto MANES, 2008

M. López Marcos, El fenómeno ideológico del franquismo en los manuales escolares de enseñanza primaria (1936-1945), Madrid, UNED Ediciones. Proyecto MANES, 2001.

Thomas Scheff, Microsociology: discourse, emotion, and social structure, Chicago, University of Chicago Press, 1990.

Remo Bodei, Geometría de las pasiones. Miedo, Esperanza, Felicidad: Filosofía y uso político, México, Fondo de Cultura Económica, 1995. 
Francisco Díez de Velasco (ed.), Miedo y Religión, Madrid, Ediciones del Orto, 2000.

Jack Barbalet, Emotions and sociology, Oxford, Blackwell Publishing, 2002.

$\mathrm{M}^{\mathrm{a}}$ Victoria del Barrio, Emociones infantiles. Evolución, evaluación y prevención, Madrid, Ediciones Pirámide, 2002.

Dylan Evans, Emoción. La ciencia del Sentimiento, Madrid, Taurus, 2002

Ramon Navarro Sandalinas, La ensenanza primaria durante el Franquismo (1936-1975), Barcelona, Promociones y Publicaciones Universitarias, 1990.

Puelles Benítez, M.: Educación e ideología en la España Contemporánea. Barcelona, Ed. Labor, 2002.

Manuel Puelles Benítez, "Evolución de la educación en España durante el Franquismo", En Tiana Ferrer, A., Ossenbach Sauter, G. Y Sanz Fernández, F. (coords.), Historia de la Educación (Edad Contemporánea), Madrid, U.N.E.D, 2002.

Robert C. Solomon (ed.), What is an emotion?: Classic and contemporary readings. $2^{\mathrm{a}}$ ed. New York, Oxford University Press, 2002. 
Doina-Olga Ştefănescu, Alexandra Florea

Cristiana Petru, Andra Maria Roescu

National School of Political Studies and Public Administration, Romania

\title{
20 Years of School Textbooks' History in Romania (1989-2009)
}

\begin{abstract}
The article compares the textbooks written during Ceausescu's regime with those published after its fall, in regards to the most important subjects of Romanians schools and expecially to the interpretation of Romania's history. The resulting stories are so different among them as to affect the young students with different ideas of country and nation. Even if it is well known that history is not neutral, the Romanian manuals show how historiography can heavily affect the identity of the single individual and the national one.
\end{abstract}

\section{Introduction}

In most cases, the historical description of an issue begins with its origins. However, history can sometimes surprise us. For example, the transition of the Eastern European states from capitalism to communism and then back to capitalism has taken theorists by surprise. This aspect encourages tackling the school textbook issue by taking into account the evolution of the last 20 years and not the first textbooks of the modern Romanian state.

These past 20 years have been very dense, though, as the transformations that have occurred during this period have a high relevance for the contemporary Romanian school. We have chosen to present the issue of current textbooks by using two possible frameworks: 
a. the historical perspective on the development of Romanian textbooks after 1989;

b. the option for pluralist models in Romanian textbooks after 1989 (examples from history and economy textbooks).

\section{An Historical Perspective on the Development of School Textbooks in Romania after December 1989}

After 1989, textbooks have undergone a reforming process, which was at first little coordinated by specific policies, but conducted under the coordination of a specialized organism after 1995, an organism specially created to ease the transition to multiple (alternative) textbooks.

The evolution of Romanian school textbooks is linked to the reform process in the educational system. In summary, the stages of this process are the following: ${ }^{1}$

- 1990-1995: Preparing the reform

After four years of dialogue between the Romanian Government and the World Bank, a reform project for the primary and secondary school was put together (RO-3724), the most extensive project of this type in Central and Eastern Europe judging by the financial allocation and coverage. The project involved a 50 million USD loan (payable in 20 years at a $7 \%$ interest rate). The Romanian Government was to contribute with 23.5 million USD, while 25 million USD were to be received from the European Union through PHARE, as a non-refundable loan.

Several components linked to the major goals of the project have been designed and have functioned within the project: curriculum, teachers training, assessment and evaluation, school textbooks, occupational standards and school management

1 M. Singer Curricular reform from design to implementation. Balance at the beginning of the millenium, in L. Vlăsceanu (ed.) The School at a Crossroad, Polirom, Iaşi, 2002, pp. 24-27. 
Several important changes have occurred in the system during this period:

- The possibility for high schools to choose their own educational profile; thus in January 1990, most high schools became theoretical high schools (from mainly industrial ones);

- Reducing the mandatory learning period from 10 to 8 years;

- Reducing the working week from 6 to 5 days;

- The elimination of the mandatory school uniform.

The textbooks used in this period were mainly the same that were used before, only without Ceausescu's picture, which had been a mandatory element at the beginning of each textbook. The great majority were still crowded, with small letters, printed in a single colour and on low quality paper. These textbooks were unattractive and difficult to read.

There were, however, textbooks that could not remain unchanged during this period, namely the textbooks for social-humanistic subjects. Subjects such as: Economic Knowledge ( $9^{\text {th }}$ grade), Social-Political Knowledge ( $10^{\text {th }}$ grade) and Political Economy. The Political Economy of the Romanian Communist Party ( $11^{\text {th }}$ grade) could not have remained in the education plans. They were replaced with Logics ( $9^{\text {th }}$ grade), Psychology $\left(10^{\text {th }}\right.$ grade $)$ and Economy ( $11^{\text {th }}$ grade $)$. The contents of the Philosophy class, taught in the 12th grade, were changed and a special textbook was created in 1990. The Humanitas Publishing House (newly founded on the ruins of the former Political Publishing House) contributed to this effort by publishing Philosophy Lessons. Shortly after that, the first restructured philosophy textbook was written, bringing a new perspective on how the subject should be studied.

Textbooks for new subjects were also written during this period:

- Civic Culture, a secondary school subject, with a textbook published in 1994;

- Human Rights, a $9^{\text {th }}$ grade optional subject, with a new textbook published in 1995.

- 1996-2000: The comprehensive systemic reform.

This is the period when the reform project for the primary and secondary education is actually carrier out. The National Framework Plan was 
created, new curricula were made for all subjects and auctions for alternative textbooks were held.

The textbook market is put together (not without difficulty). In a few years' time new textbooks for all grades are published on the basis of the new curricula. Textbooks are of an improved quality: they become learning instruments with special graphics and are printed in colour. For each subject, the Ministry of Education purchases three alternative textbooks, on the basis of the scores received at the auctions. The alternative textbooks are translated in Hungarian and German. In 1996 Civic Education begins to be taught in $3^{\text {rd }}$ and $4^{\text {th }}$ grade. The first alternative textbooks for this subject are published.

- The 2001-2009 period

This period represents the slowdown and even the stopping of the reform, sometimes returning to old methods and taking measures that would discard previous achievements. Policies to continue the reforms are missing, allowing unfavourable decisions to be taken. Long term strategies in education are missing.

However, there have been some attempts to continue the reform in this time span. We offer some examples:

- 2005 - Publishing the Report on the State of the Education System report which shows, through its indicators, where we are, as well as evolution tendencies.

- 2006, 2007 - The project Needs and Priorities for Change in Romanian Education - this was the basis of development and modernisation for pre-university education.

- 2008 - Setting the strategy Education and Research for the Knowledge based Society by the Presidential Commission for the Analysis and Policy Making in the Educational and Research Field. Singing the National Pact for Education by all the parliamentary parties' leaders on the 5th of July 2008 and then by the Romanian Academy and 22 trade unions, student associations and the parents' association.

- 2009 - Dialogue attempt between the powers of the state to continue the education reform (influenced by the electoral campaign, though). From the textbook point of view, a return to traditional, conservative models can be noticed in the textbooks promoted. 


\section{The Option for Pluralist Models in School Textbooks in Romania after December 1989}

The single model paradigm has functioned for a lot of years in the Romanian education system. Almost 50 years of communism have determined important changes in the strategies of handling issues promoted in textbooks. Everything had to be interpreted in a partisan manner. The evaluation of any theoretical position had to be made from the standpoint of a "valid" theory, which was the communist ideology. Due to this state of affairs, everything that was present in textbooks represented the officially accepted point of view and any other position was considered wrong by default. This way of writing textbooks could not be replaced immediately after 1989. Many textbook authors have continued to search for the "truth", generating many disputes regarding the way it had been presented. Pluralist models have been promoted gradually, as even the idea of alternative textbooks imposed on them the effort to make the possibility available (in teaching, learning and evaluating).

We now move on to present the evolution towards pluralism in the case of school textbooks for Economics (high school education, textbooks for the $10^{\text {th }}$ and the $11^{\text {th }}$ grades) and for Romanian History (secondary education, textbooks for the $8^{\text {th }}$ grade).

\section{Economics Textbooks}

To identify how the transition was made from a unique approach to a pluralistic one regarding Economics as a high school discipline, we turned to a brief review of existing student's books for between 1989-2006, taking into account the three periods considered in the development of post-communist school textbooks. The textbook from 1989 was set as a benchmark and the analyse followed the following points:

a. to what extent information is offered to students from the axiological perspective in textbooks after 1989; 
b. whether the authors of textbooks considered it appropriate to provide students with alternative references, and if they did, what type of sources appeared the most (press articles, world-renowned economists, public figures, other economics textbooks);

c. the extent to which various schools of economic thought are presented to students.

Economic science, as presented in textbooks for high school students, appears rather as something given, but, as in any social science, its truths are not perfect. A short presentation of various schools of economic thought is a good sign of a pluralistic approach. Even if the entire content of the textbook presents economic science in its mainstream version, a review of other schools of thought puts the student in a position to critically assess the strong and the weak points of each theoretical approach.

Some new generation textbooks also focus in the same way on the presentation of various systems of economic organization. The fact that market economy exists, that one learns about it through daily interactions and at school does not imply, however, the universality of the concept. It is important for students to be familiar, at least theoretically, with other types of economic organization, and to be able to understand the process during which the transition from subsistence economy to market economy was made, to understand that market economy is an alternative to planned economy.

\section{Communist Textbooks}

The 1989 textbook is strongly ideologised. Its structure is an interesting one though, as the book is divided in two sections: a considerable section of the textbook is devoted to socialist economy, while the other one is devoted to capitalist economy. The section dedicated to socialist economy presents all the issues from a Marxist perspective with reinforcements from Nicolae Ceausescu's speeches.

"I believe - highlighted comrade Nicolae Ceausescu - that in our socialist society, no one should, and no one could earn an income without 
work, by exploiting and appropriating the labour of others, by actions of speculation".2

The economic truth is strongly distorted by the party's "truth", the information coming together with the ideological idea of "good" as defined in the communist system.

The section dedicated to capitalist economy presents mathematically correct concepts such as profit or salary, although completely ignores issues like inflation or unemployment. Beyond the accuracy of mathematical formulas, phrases incriminating the capitalist order appear in every lesson, reinforced by the interpretations of Nicolae Ceausescu:

Comrade Nicolae Ceausescu stressed in his 1988's Exposure that developed capitalist countries have undergone a process of accumulation of wealth in the hands of an increasingly smaller group of people who have become richer, and of increase in the number of poor, whose basic minimum conditions of work and life are not guaranteed. ${ }^{3}$

\section{Textbooks from 1990 to 1995}

The textbooks studies from this period are unique textbooks, each being a republication of the preceding, with the addition of one or more chapters. First, it should be noticed that the content had been adapted to the new realities, there being present problems such as unemployment, inflation, transition to market economy in Romania.

The approach is neutral from an axiological point of view, the textbook providing information on economics, not a predefined idea of "good" related to it. Although other sources of documentation are not explicitly recommended, the book provides at the end of each chapter fragments belonging to famous economists for students to comment. Here are some examples:

2 F. Burtan (ed.), Economie politică. Politica economică a Partidului Comunist Român. Manual pentru clasa a XI-a, Editura Didactica şi Pedagogică. Bucureşti, 1989, p. 128.

$3 \quad$ Ivi, p. 50. 
John Kenneth Galbraith: As long as it is considered that the economic system works, ultimately, in the interests of the individual - that it is subordinated to his needs and desires - we can presume that the role of economic science is to explain the process through which the individual is served $[\ldots]^{4}$

Milton Friedman: Viewed as means of achieving political freedom, economic relations play an important role in the dispersal of power. The type of economic organization that directly generates economic freedom, namely competitive capitalism, also promotes political freedom because it separates economic power from political power and thus allows a balance between the two. ${ }^{5}$

Students are given problems to solve, texts and tables to interpret, this kind of tasks creating the premises of a flexible, pluralist approach, free of a need for a single, absolute and nonnegotiable truth.

\section{Textbooks from 1996 to 2000}

Textbooks from the following period are alternative textbooks, not only bringing a wider set of problems and applications, but also showing the evolution in time and space of the economic activity and economic theory. Economics is presented as a social science that evolves over time through different schools of thought and adapts itself to different types of realities.

For instance, the 2001 textbook published by Antet Publishing house makes these aspects clear from its first two chapters, which are devoted to "Economy as a Social Science" and, respectively, to "Economy as a Real System". In the first chapter economical schools of thought are listed from physiocracy, the English Classical School and its representatives such as Adam Smith, David Ricardo, Thomas Robert Malthus, John Stuart Mill, and continuing with protectionism, the theory of value labour (Karl Marx), the neoclassical school, the marginalist Austrian school, the school of Lausanne (general equilibrium theory), the Cambridge school, Keynesianism. ${ }^{6}$ The second chapter is focused on real economy and economic

4 P. T. Ghiță (ed.), Economie. Manual pentru învăţământul liceal, Editura Didactică şi Pedagogică R.A. Bucureşti. 1995, p. 8.

$5 \quad$ Ivi, p. 19.

6 I. Cavachi, Economie. Manual pentru învăţământul liceal. Editura Antet. Bucureşti, 2001, pp. 8-9. 
systems are briefly presented here: the natural economy, the economy of exchange and the free market economy, the system of command economy, mixed economy and transition to market economy ${ }^{7}$.

In this generation of textbooks there is a great emergence of several resonant names for economic science: Adam Smith, David Ricardo, Thomas Robert Malthus, John Stuart Mill, Paul Samuelson, Michel Didier, R. Fogel and D. North, Turgot, Gilbert Abraham Frois, Paul Heyne.

In addition, all textbooks from this period have consistent chapters on of Romania's integration in the European Union and on international financial bodies, drawing attention to an economy that tends to become global, that relies increasingly on interdependencies and that has both advantages and disadvantages for the stakeholders. Both free market principles and the role and capacity of national states to deal with the international economic environment are analysed.

\section{Textbooks from 2001 to 2009}

A selective bibliography was introduced at the end of the textbooks printed in 2002 and 2006, making the reference to other recent readings in a more explicit way than before (using both local and international literature as reference sources). The textbook thus becomes a support material for the study of economics, and not an absolute source of truth concerning economic science.

Another sign of moving towards a pluralist approach is the introduction of texts from a totally different register than before, namely from the economic press, sometimes in its online version. For example, the textbook from Niculescu Publishing house (2006) contains at the end of each chapter a section called "Press on" containing fragments from economic press articles on current issues, challenging students to interpret contemporary economic realities by using theoretical knowledge gained during classes:

From 2003 until now, in 2006, a real brand cult has been developing. Romanians discover promotions, a diversification and stratification of brands. Exigency, security, 
accessorizing, pragmatism, all these become keywords in the purchase behaviour of Romanians. The characteristic verb now is TO ACQUIRE. Over the last years, Romanian buyers have evolved from simplicity (in 1996), to availability (in 2000), to stability (in 2003) and finally to exigency. ${ }^{8}$

At mid-year, Romtelecom lost nearly 200,000 subscribers, from 4.3 to 4.1 million subscribers, compared with the similar period in 2004. And other alternative operators have won market shares from $4.1 \%$, at mid-year last year, to $10 \%$, and 430,000 subscribers at the end of 2005, according to ANRC. Among these stand out RCS \& RDS and UPC Astral Telecom, which provide triple-pay packages (TV, internet and telephone through the same wire). ${ }^{9}$

Although veiled, the pluralist message is quite clear: economy is a reality that we live, that we read of and write about using both academic and less academic sources, and any person familiar with the economic reality and language may issue opinions, estimations, forecasts that can be taken into consideration.

In conclusion, there is a positive trend the process of democratization in terms of learning economy at high school level, with progress from one generation of textbooks to another. Without being complete yet, the transition to a pluralistic approach is clearly distinguishable.

\section{History Textbooks}

The study of 8th grade Romanian history textbooks has aimed at achieving a comparative analysis of the textbooks written between 1989 and 2009, by focusing on how two major themes of the history of the Romanians are described in each book: the genesis of the Romanian people and the communist regime. The study of the two themes has pursued:

a. the content presented to pupils;

b. different approaches, as signs of pluralism.

8 I. Gavrilă, Economie. Manual pentru clasa a XI- $a$, Editura Economică Preuniversitaria, Bucureşti, 2006, p. 24.

$9 \quad$ Ivi, p. 71. 
There has been no new auction for history textbooks for secondary school after the year 2000. Under these conditions, the comparison has been made directly between the textbooks used during the communist regime and the ones used today.

Romanian History is one of the fundamental subjects taught in Romanian schools. History has been and still is a subject tested in national assessments. Given the fact that history has been used as an instrument of propaganda in the communist period, by distorting and remodelling the information so as to serve the interests of the Communist Party, the analysis of the way the content of textbooks for the $8^{\text {th }}$ grade has changed, after returning to democracy, becomes meaningful. The topics included in the present analysis have been selected by taking into account the falsification of the history during the communist regime and pursuing the development of several of the most controversial and rewritten events in the history of Romanians.

\section{The Genesis of the Romanians: the Centralized Dacian State and the Continuity Thesis vs. the Immigration Thesis}

In the 1989 textbook, the genesis of the Romanians is put in Marxist terms, as being the result of a class antagonism in the ancient Dacian society. Therefore "the cleavage of the Dacian-Getic society in antagonistic classes has led to the formation of the state, as the dominant class, the nobility, required an instrument which would ensure its reign and the possibility of exploiting those who worked [...] the Dacian state is a military monarchy [...] it is politically centralized, the whole Dacia being submitted to the will of the king" ". Moreover, after being conquered by the Romans, the society will divide again in two antagonistic classes, with the Roman conquerors as the dominant class.

The presence of two classes in Dacia is also mentioned in the textbooks written after 1989 (nobles and common men), but there is no mention of

10 H. Daicoviciu, P. Teodor, I. Cîmpeanu, Istoria Antică şi Medie a României. Manual pentru clasa a VIII-a, Editura Didactică şi Pedagogică, Bucureşti, 1989, p. 33. 
class exploitation. Burebista unifies all the tribes and becomes king, but does not establish a centralized state. After the Roman conquest, Dacia is not seen as being exploited by the dominant Roman class, but as being a "Roman province" where the locals will undergo a Romanization process.

Unlike the 1989 textbook, where only the continuity thesis is presented and sustained, all the other textbooks present the context and the dispute between the continuity and, respectively, the Romanian immigration theses. While the continuity thesis speaks about the formation of the Romanian people north from the Danube and of the contribution of the migrant people, the immigration thesis considers that the Romanian people has formed south from the Danube and has then immigrated to the land left unoccupied after the Dacian-Roman wars. The genesis of the Romanians is presented in a pluralist manner, as the four textbooks sustain and argue in favour of the continuity thesis, but also present the challenging vision and its arguments.

\section{The Communist Regime}

There are major differences in the way the communist regime is presented. For the 1989 textbook, this theme represents an occasion to worship Nicolae Ceausescu and his wife, as the personality cult being a common presence in textbooks.

The textbooks written after 1989 divide the communist times in two major periods:

a. the Dej period or the Stalinist period, when the Romanian society has undergone the Stalinization process

b. the Ceausescu period or the period of national-communism, of the dynastic regime or the neo-Stalinist period.

All textbooks mention the single party, the planned economy, the five year plans, the repression, the political crimes, the political prisons and the forced labour centres (Pitesti, Gherla, Sighet, the Danube - Black Sea canal), the Stalinization and the reverse process, the detente period, the personality cult of Ceausescu, the economic decrease, the fall of the communist regime and the revolution in 1989. 
However, there are significant differences between the way these aspects are presented and the periods divided:

- The 1992 Didactica si Pedagogica Publishing house textbook gives a global view of the facts, highlighting the international context and linking the characteristics of the Romanian communism to the evolution of the Romanian - Soviet relations. It divides the Ceausescu period in three: the détente period 1965-1971, the personality cult period 1971-1980, the economic fall period 1980-1989. It only briefly mentions the events that occurred in 1989 in Romania, choosing to emphasize the fall of the communist regimes throughout Europe.

- The Sigma Publishing house textbook speaks of propaganda as means of legitimising the party and its actions, and also as means of social control. It links the re-education experiment at Pitesti with the obsession for creating the "new man". It divides the Ceausescu period in only two stages: the consolidation period, a détente period when the tactics of "weakening the screw" was applied (1965-1974), and the cultural revolution and the economic fall period (1974-1989).

- The Teora Publishing house textbook puts little emphasis on the international context, highlighting the main events and changes within the country. It is very interesting to note the four-period division it makes of the Ceausescu regime: 1965-1971, 1971-1980, 1980 -1987, 1987-1989. It also mentions the dissidents of the 1980s and their actions: Paul Goma, Gabriel Andreescu, Ana Blandiana etc. The 1989 revolution is extensively described and the events in Timisoara are explained.

- The Humanitas Publishing house textbook sees the expansion of the Soviet influence as being a result of the abandonment of Eastern and Central Europe by the Anglo-Americans. It defines the principles of political Stalinism - the single party sustained by the political police, economic Stalinism - centralized economy based on state ownership, and cultural Stalinism - ending all relations with the Occident and applying the Soviet model - "proletcultism". The Ceausescu regime is described as neo-Stalinism or dynastic socialism and it is divided in two periods: the détente (1965-1974) and the dynastic socialism after 1971/1974. It mentions the systematization plans of towns and villages and the numerous demolitions. It also mentions the dislocation of the rural population and their forced urbanization. 


\section{Bibliography}

D. Ailenei, Economie. Manual pentru clasele a X-a şi a XI-a, Editura SIGMA, Bucureşti, 2000.

F. Burtan (editor.), Economie politică. Politica economică a Partidului Comunist Român. Manual pentru clasa a XI-a, Editura Didactica şi Pedagogică, Bucureşti, 1989.

I. Cavachi, Economie. Manual pentru învăţământul liceal, Editura Antet, Bucureşti, 2001.

V. Cornescu, Economie. Manual pentru clasele a X-a şi a XI-a, Editura ALL Educaţional, Bucureşti, 2001.

A. Crişan (editor), Four Exercises of Education Policy, Humanitas Educational, 2000+ Publising House, Bucharest, 2006.

O. Cristescu, V. Păsăilă, B. Teodorescu, R. Tomi, Istoria Românilor. Manual clasa a VIIIa, Ed. Didactică şi Pedagogică, Bucureşti, 1992.

M. Dudian, Economie: Manual pentru clasa a XI-a, Editura Niculescu, Bucureşti, 2006.

H. Daicoviciu, P. Teodor, I. Cîmpeanu, Istoria Antică şi Medie a României. Manual pentru clasa a VIII- $a$, Editura Didactică şi Pedagogică, Bucureşti, 1989.

I. Gavrilă, Economie. Manual pentru clasa a XI-a. Editura Economică Preuniversitaria, București, 2006.

P. T. Ghiţă (editor), Economie. Manual pentru învăţământul liceal, Editura Didactică şi Pedagogică R.A., Bucureşti, 1993.

P. T. Ghiţă (editor), Economie. Manual pentru învăţământul liceal, Editura Didactică şi Pedagogică R.A., Bucureşti, 1995.

V. Georgescu, Politică şi Istorie. Cazul Comuniştilor Români 1944-1977, ed. Humanitas, Bucureşti, 2008.

C. Gogoneaţă, Economie. Manual pentru clasa a X-a, Editura Humanitas Educaţional, Bucureşti, 2000.

M. L. Lăcătuş, Economie. Manual pentru clasele a X-a şi a XI-a, Editura Corint, Bucureşti, 2002.

L. Lazăr, V. Lupu, Istoria Românilor. Manual pentru clasa a VIII-a, ed. Teora, Bucureşti, 2000.

S. Oane, M. Ochescu, Istoria Românilor. Manual pentru clasa a VIII-a, Ed. Humanitas Educaţional, Bucureşti, 2000. 
M. Singer, Curricular reform from design to implementation. Balance at the beginning of the millenium, in L. Vlăsceanu (editor) The School at a Crossroad, Polirom, Iași, 2002.

A. Vulpe, R. G. Păun, R. Băjenaru, I. Grosu, Istoria Românilor. Manual pentru clasa a VIII-a, Ed. Sigma, Bucureşti, 2000. 



\title{
"Forming the Eminently Moral and Able Man" The Reading Books after Unification
}

\begin{abstract}
This essay describes the evolution of textbooks in the primary and secondary Italian schools after the Unification of Italy, showing how textbooks have been used by the political and intellectual élites to forge Italian young people in loving and appreciating the new "unified country".
\end{abstract}

\section{Introduction}

The Italian children's reading books (at the end of the 1800's when about $2 / 3$ of children were obligated to attend school) are a useful observatory certainly not unique - to gather data about the education of those Italian children who were introduced to a common national destiny; these books were the only general books in the elementary schools.

Despite the fact that school books expected by the ministerial regulations in the first three classes (the obligatory ones) were listed as follows in a circular from 1875: "the spelling book, the first composition readers of the spelling book, the first reader, the catechism (the "little one" that doesn't apply to the other classes), the stories of Sacred History, the abacus, the arithmetic handbook, the penmanship models and also the penmanship notebooks"', the young students' backpacks were almost empty.

1 Law of 30 January 1875, n. 868. Regarding the reconstruction of complex normative passages that have marked the educational and editorial events of textbooks refer to the scrupulously gathered documentation by A. Barausse, Il libro per la scuola dall'Unità al fascismo. La normativa sui libri di testo dalla legge Casati dalla 
Generally the children had only the reading books, not always the arithmetic (in any case the reading books also brought in the appendix the basic notions to learn how to count) and, when religious teaching was expected, the catechism or of sacred history books.

The reading books were publications of few pages, compiled in general by teachers and school inspectors, with very unpretentious typographical characteristics and sold for a few cents. It was only from the fourth class (attended however only by the minority of students that continued studies beyond the years of obligatory instruction: in 1878 the upper classes and namely the fourth and the fifth represented just $11.9 \%$ of Italian schooling ${ }^{2}$ ) that other textbooks appeared such as those of grammar, history, geography, natural sciences, civil rights and moral duties, the last being the new subject introduced by Minister Coppino in 1877. The history books were introduced in the lower elementary classes only at the end of the $80 \mathrm{~s}$, almost thirty years after the proclamation of the Unification.

At the disposal of the youngest students there were also other pleasant and entertaining reading books in which the patriotic or at least the ethical civil topics were recurring. The books, in this case, were written by important writers like Cesare Cantù, Giulio Tarra, Pietro Thouar, Luigi Sailer and, later, Ida Baccini, Collodi and De Amicis. ${ }^{3}$

The circulation of this genre of publications was still limited to literate environments and only marginally touched the lower classes and the urban working class to which the only familiar book was the textbook. It is for this reason that the textbook is a privileged document for data on how the education of the little Italians was conveyed.

The principle prototype of the modern reading book was the $\mathrm{Gi}$ annetto, a text that appeared in 1836, by Luigi Alessandro Parravicini, professor of methodology and director of the normal school of Como. This is a book that was continually reprinted and used, also in revised and reduced forms, both as a school manual and as a popular cultural book. Based on the educational and the family events of the protagonist,

Riforma Gentile (1861-1922), Macerata, Alfabeta Edizioni, 2 voll., 2008, is very useful.

2 These facts and others on the school attendance see in S. Soldani, La nascita della maestra elementare, in S. Soldani, G. Turi (editors), Fare gli Italiani. Scuola e cultura nell'Italia contemporanea, Bologna, Il Mulino, 1993, vol. I, pp. 89-90.

3 P. Boero, C. De Luca, La letteratura per l'infanzia, Torino, Einaudi, 2009, pp. 18-42. 
Parravicini arranges the notions useful to Giannetto in five chapters: the role of a man, what are his duties in the society, what are his land and country, the moral examples useful to improve him and the teachings taken from the historical events.

This plan was destined to last for a long time, supported by the orientation of the educational programs from 1860 on: not only the reading books would often use for their titles children's names, but they would also have kept in mind the practical sense of the didactic and pedagogical establishment of Giannetto until the passage between the two centuries. These books were considered "the real center of gravity of a popular school", because "they must have provided material for the enhancement of teaching/learning the language and the culture, and the moral and civil education" needed "not to please", but to form the "eminently moral and able man, so that in performing his duties and in protecting his rights, he can be sufficient to himself with decorum and with minimal disturbance possible from others, properly and validly sustaining the struggle of life" .

The model of a "practical" and "useful" book - and educational exactly as much as "practical" and "useful" -was based on the idea of providing unpretentious educational knowledge that shouldn't cultivate ambition for successive studies and not even keep fantasy awake.

Marginal place was allowed to fantasy and the fantastic. It was for this reason that the ministerial commission appointed in 1883 to assess useful texts, expressed a severe judgment on Pietro Thouar's and Carlo Collodi's works, who in 1877 had attempted the educational trend with his Giannettino. According to the ministerial censors the two Tuscan writers' works were ill-suited to develop good citizens because they were "too romantic in their nature by inspiring superficial ideas and not useful ones"s.

4 P. Fornari, Libro di lettura, in Dizionario illustrato di Pedagogia, Milano, F. Vallardi, s.d., vol. II, pp. 519-420.

5 Ministry of Public Instruction - Report on the textbooks, Relazione generale a S.E. il Ministro, Presidente del Consiglio Superiore della P.I., Roma, Tipografia Sciolla, 1883, p.11. 


\section{A "Simple, Natural, Practical and Therefore Very Effective" Book}

All of the educational programs for the elementary school from 1860 until the educational reform of 1920 assigned a fundamental importance to the reading books. The programs of $1867 \mathrm{had}$, for example, a specific paragraph for them. These books, by being gradually suitable for the intelligence and age of the students, had to stimulate "their intellect and heart," by avoiding every "superfluous futility".

Also in the Istruzioni [Instructions] of the following programs (1888), the issue of the reading books was strictly associated with the practice of reading and the teaching of the Italian language with a strong call to convenience and concreteness. Instead of following "elegance" and "fluency", the school teacher was asked "a very important matter": to ensure that his students would have understood well what they were reading. At the end of the reading, the teacher had to inquiry if the students had understood "clearly" and, in case the situation required it, he would have explained the less common terms. Lastly, the teacher had to reread the text "accentuating the prepositions and the period in a way that lucidly explains it", then have the students reread it another time. ${ }^{6}$

It is not a coincidence that the manuals on pedagogy on which the teachers were trained emphasized "how to explain the textbooks" and how "to make them understood by the students". The data on the periodical pedagogical conferences organized by the minister in various parts of Italy at the beginning of the eighties to increase the teachers' preparation, also emphasis the strategic focus on the reading books.

This insistence is suspicious and seems to suggest that the reality was much different than what appeared in official documents. We know that many teachers were having difficulty, at least close to unification, even with the correct usage of the Italian language. ${ }^{8}$ In addition, many teachers preferred to give some notes instead of using official textbooks. In sum,

6 E. Catarsi, Storia dei programmi della scuola elementare (1860-1985), Firenze, La Nuova Italia, 1990, pp. 211-212.

7 See for example P. Vecchia, Pedagogia per i maestri di grado inferiore, Torino, Paravia, 1969, pp. 84-92.

8 G. Talamo, La scuola. Dalla legge Casati alla inchiesta del 1864, Milano, Giuffré, 1960, pp. 205-290. 
the textbooks were not universally adopted in the forms that today we are familiar with and often different books were used within the same class. The textbook entered the class quite slowly and only upon the powerful ministerial demands and those, no less powerful, of the editors.

Other ministerial documents showed the demand for concreteness and convenience mentioned earlier. In the reduced time spent at school by the students it was required to make every effort to transmit few and useful notions. The circular from November 12, 1882, dedicated to the choice of books, for example, informed that the reading books needed to "have [...] elementary notions of hygiene, natural sciences, history and geography within tales, moral stories, and easy poems" with "special connection to small town life and therefore to the arts, industry, and commerce (in the urban school) and to the agricultural works (in the rural school)", not forgetting to care for "the special mission of the woman in the family and in society". The successive request of 1884 which launched a call for new textbooks, clarified that to be "useful and delightful" the reading books had to be "different for rural and urban schools: the students of these two kinds of school live in different environments and they aim toward different destinations" $" 10$.

Upon reviewing these books, it is possible to gather the perspective on infancy (an infancy to discipline on the behavioral level and to rapidly insert in the productive cycle, a somewhat adult conception of infancy), but also on one of the phases of life in which the socialization and integration of the working classes to the new Nation would have occurred.

The textbook has in fact a symbolic value that goes beyond the school picture: its entrance into houses is an occasion to discriminate between literate and illiterate people; it becomes the sign of a new way of living based on the capacity to read and write; it represents the liberation of the new born Italy from ignorance and lack of culture. It becomes a custom to donate books, promote reading and award the best students with special books (the "prize books"), better edited and richer with illustrations compared to the usual and boring textbooks ${ }^{11}$.

It is emblematic that among the topoi in the infancy readings there is the one about the virtuous child that amorously preserves his books as

9 Circular of 12 November 1882, n. 688.

10 D. M. 31 July 1884.

11 E. Becchi, D. Julia (editors), Storia dell'infanzia, Vol. 2., Dal Settecento a oggi, Roma-Bari, Laterza, 1996, pp. 166-167. 
opposed to the bratty child that wrinkles them, scribbles on them or even, like Pinocchio, sells them. While for the first child, we envision a bright and happy future and, possibly, economic fortune, for the second, his destiny includes poverty and moral misery.

\section{Becoming Italians Through the Knowledge of Language}

The mastery of the Italian language is the first requirement to be able to participate in a better future. They become honest citizens and good Italians, first of all, because they speak the Italian language. The dispositions of the programs of 1867 stated very clearly:

Extremely important is the study of the Italian language. Every effort of a wise teacher needs to target this aspect. He needs to use the national language while teaching, and with frequent talks, to demand the young students to do the same, and to correct with fond patience those imperfections originating from provincial dialects. He can use the dialect only when the Italian words are not yet familiar to the students ${ }^{12}$.

Both these choices to overcome the linguistic incommunicableness among citizens of different regions, in reality occurred along a different path than the popular customs.

In the years of Italian unification the Italian-speakers represented in fact the absolute minority. The use of the Italian language by most of the common people "was not normal, but exceptional, not spontaneous, but desired and, with respect to the naturalness of the use of dialects, artificial"13. From the survey of 1864 on the condition of elementary schools, the inspectors denounced the universal ignorance of the Italian language. Banning dialect from schools was almost impossible, but the insistence on the use of the Italian language and in the difficult activities to do it, summarized a pedagogical and civil message of multiple meanings.

In the first place, it meant the overcoming of local traditions: it did not deal as much with negating them as declaring the inadequacy of the single local linguistic cultures with respect to the priority assigned to the

12 E. Catarsi, Storia dei programmi, cit., p. 201.

13 T. De Mauro, Storia linguistica dell'Italia unita, Roma-Bari, Laterza, 2008, p. 44. 
national tradition. This implicated collecting together the different local histories in one big "country" that would have used only one language. This single linguistic ideal was considered at the basis of the moral Italian unification according to those schools of thought on a single language in a single nation pursued above all in the romantic period by intellectuals and politicians, or rather by the entire ruling class.

Therefore, the use of the Italian language was conceived as an instrument of the country unification, but also of the homologation of the Italian people. To reach this goal it was long discussed if it were possible to concentrate the education of teachers in Florence so as to promote a common language and to facilitate, through the action of teachers, the circulation of Italian.

We cannot forget the heritage and role of the unified language by the cultivated that is a solid a point of reference. The pride for the greatness of one's language projected itself toward a future of Italy that is the worthy heir of a glorious past.

The teachers, at least those most open-minded, strived to facilitate the memorization of Italian terms through the use of illustrated posters that smart editors (like, for example, Paravia and Vallardi) put at schools' disposal. It was frequent that in educational practices the use of dialect was punished with little sanctions. The teachers would underline the inadequacy of speaking the vernacular as opposed to the austerity and the importance of the school symbolized in the use of the Italian language. Dialects were considered real "obstacles" to the unification of Italians, "errors" to eradicate as soon as possible.

Some scholars, like for example Isaia Ascoli, Francesco D'Ovidio and subsequently Ernesto Monaci, asserted in vain the value of the linguistic dialectal legacy. Only later, with the school reform of 1923, some aspects of the dialectal way of speaking were appreciated because of the initiative of Giuseppe Lombardo Radice.

The Italian language constituted therefore the first real and very demanding introduction of children to the notion of "single nation". However, both ideas (single language in a single nation) appeared vague and unfamiliar to the children, certainly distant from the resounding declarations that they could hear in political debates.

This distance was known to teachers who, after unification, pushed the class toward the linguistic unity, having care not to uproot the future citizen from his original environment and culture. 
There was full awareness that the education of the internal law would have taken place through ethical codes often different than the civil religion that nourished the ruling elite. This objective was pursued by organizing a great variety of books able to satisfy the demands of the different types of schools and students: urban schools, rural schools, boys' schools, girls' schools, and night and holiday schools for adults. This production was followed by the creation of small dictionaries (at times in the appendix of the same reading books) of the various Italian dialects to facilitate the comprehension of Italian.

The belief that each educational reality needed, in other words, its own specific typology of text documented not only the pedagogical intention to turn to different narrative modalities to stay coherent with the different infantile experiences, but also the realism with which the ruling class looked at school, conscious of having groups of students socially and geographically heterogeneous among themselves, but all having and in need of a specific language.

\section{The Nation as an Extension of the Family and of the Native Village}

In the reading books of the first elementary classes the pedagogical focus was placed on the education of an adult capable of actively joining the community life, with respect to the laws and the current social norms focused on the decorum and the wellbeing of the body, the importance of work, and those moral rules that marked a clear distinction between good and bad. Short readings of moral content intertwine with popular legends, simple scientific notions useful to contrast beliefs and prejudices, readings on Italian geography and on great Italians.

The general ethic education precedes the education of the Italian or, if one prefers, the education of the Italian rests on a solid and concrete ethical conception of human life rooted in the precise place where destiny places everyone's life. The image of Nation is portrayed like the natural appendix of the family and the native village. The village and the concrete experiences that animate it - from those practical and economic to those 
linked to feelings and social relationships - constitute the symbolic introduction to the greater nation.

The topic of the village wisely guided by authority, with its farmers and hardworking artisans, respectful of the laws and supportive of each other represents, since Giannetto and Cantù's short stories, a recurring theme in the popular and educational narrative. In addition to this, the house is described as a place of emotional security and protection, as so exemplarily presented in this passage by Ida Baccini:

How many pains, how many pleasures, how many kind regrets awaken in us these words: "Our home!". All men, from the least well-off to the most rich, from the most educated to the most crude, have this shelter that protects them from the season's bad weather: all men, good or sad as they may be, possess a little room, a corner, a closet, where they rest and they cheer up; where they pray, love, cry. [...] Love at home was the first introduction to civil living, to obedience to laws, to reverence for the Nation. One cannot love his country if he does not love his home: and one could badly defend someone else's children if he does not feel tenderness for his own ${ }^{14}$.

The enhancement of the native home - in textbooks for urban schools where the village was replaced by the small town - did not respond only to the didactic demand to depart from the infantile experiences by introducing the concept of a larger geographic entity. The objective was to orient the vigorous local feelings toward a still unknown and abstract reality for most, Italy. The notion of "my country" precedes that of nation: the first, because of the experiences with their strong emotional element - with a call to filial love -was more appropriate to represent the community of citizens united by common customs, territory and language with respect to the most properly historical, political and ideological element that was the modern idea of nation.

Pietro Thouar, a particularly prolific and fortunate author, thus imagines how a teacher speaks to one of his students at the beginning of the new academic year:

It is necessary that you prepare to be a useful citizen; like the vine cuttings, which, although not yet making grapes, is also cultivated by your father with care, until it becomes a good vine. The nation, thinking of you, does not wait that you grow up and become a man. The school to educate and instruct the children is a cost for the

14 I. Baccini, Terze letture per le classi elementary famminili, Firenze, Felice Paggi, 1882 , p. 35-26. 
local administration and the State. Similarly the farmer, to fertilize the land, does not expect that the wheat grows... You see therefore that your obligation, as much toward your parents as toward your country, begins, one can say, from your birth; and that as soon as you are able to use your reason, you have to recognize it, and you have to handle yourself in a way to satisfy it. ${ }^{15}$

The native country is associated to the rural world of children and is joined by the presence of parents, almost to represent it as a big family. With the same concreteness in addressing the young girls Baccini referred to the feeling of belonging to the country and the obligations that derived from it, feelings presented to everyone's reach, without heroism:

The country needs good citizens, distinguished men, who with the example of their virtue and of their greatness grow decorum, and make their name always more respectable. Beautiful is the enthusiasm that pushes the young volunteer on the battle fields, between the loud noise of the trumpets and the neigh of the tremulous horses: but holy is the exercise of those modest and perseverant virtues, which the sanctuary of the family guards and hides. Also you girls, children, you have duties toward the country. You must study until becoming sound, hard-working, and honest. You will acquire health, or you will preserve it, with hygiene and exercise; industriousness, with educating the mind and heart at the same time; honesty, with love at work. ${ }^{16}$

The duties that link each person to one's own land were consequently adopted as models for a good citizen's duties. We mentioned "duties" because the "rights" will appear only a little later when, in 1877, the subject "Rights and duties of the citizen" will appear in the elementary school and by doing so replacing the educational values traditionally represented by the Catholic religion with a more civic oriented education based on secular feelings.

The first duty is that of "deserving life" through work by way of being self-sufficient. The good worker will be honored for his own sweat and will draw with it the joy of staying away from the idle generator of vices, will know how to take care of his own family with dignity and by means of saving to anticipate and contain the possible difficulties arising by unforeseen causes. Work serves to temper the character, to learn how to

15 P. Thouar, Letture graduali con nuovi racconti per fanciulli ed una scelta di esemplari di buono stile, cavati dai migliori scrittori italiani, Firenze, Tip. Galileiana, 1860, p. 197. The Letture were continuously republished, with some adaptations needed because of the changing of school programs, until the end of the century.

16 I. Baccini, Terze letture per le classi elementary femminili, cit, p. 51. 
survive in a world full of difficulty and accidents. The textbooks are full of virtuous examples through which they presented different occupations to young students, but also the ethical values joined to a trade and the capacity to regulate the expenditure of the working condition.

This vision on managing the job and on the good father's ability is associated to those suggestions on how to "choose a state": too high expectations are fatally destined to generate disappointments, but the fatalism of the irreparable immutability of one's own condition is not appreciated as well.

Two professions are indicated as particularly appropriate to encourage the virtues of industriousness and initiative: that of the small merchant that saves money, giving up fun and luxuries and that of the artisan who works until becoming the owner of a small factory ${ }^{17}$. It is about the anticipations of that self-help culture that will hugely circulate in the Italian schools mainly after 1880 . The protagonists of these stories do not detach themselves from the work which their condition destines them to have, but concentrate their energies on performing it with a regularity that will earn them honest prosperity.

To the duty of work is associated the duty of instruction. The man who does not fulfill his school duties in tender age is strongly denigrated, considered a useless and burdensome weight for the civil society, a person without honor. Missing the educational obligation is a sign of roughness and ignorance, in addition with fabrication, dishonesty, wickedness, idleness, drunkenness, and violence against animals. Instruction and school are exalted as the sign of civility and progress. The teacher is described as a benefactor of humanity, object of admiration and deserving of social appreciation.

Two other duties were frequently transmitted through the textbooks since the first years of elementary school: the tax payment and the military service. It was not sufficient "to love the country" by words: to demonstrate it tangibly in behavior was specifically required.

A harmonious cohabitation depended on the civic sense of contributing to common costs (roads, schools, the defense of one's native soil, etc.) to which the citizens were held to contribute to "in proportion to their possessions". Military service was presented to the young students as indispensable for the protection of their country and the maintenance of its independence. Much insistence on the civic importance of military service - constant in all textbooks of the time - responded to the necessity

17 M. Bacigalupi, P. Fossati, Da plebe a popolo. L'educazione popolare nei libri di scuola dall'Unità d'Italia alla Repubblica, Scandicci, La Nuova Italia, 1986, p. 69. 
to win the resistances by the lower classes for the time spent while serving. Being a soldier was a duty and "a beautiful thing": while at school the child learned to respect the discipline imposed by the teacher, "as a soldier who would have obeyed to his officials"18.

Since the first classes, short stories and simple poems to enhance the military uniform were presented, like the following one Che peccato essere piccini! (What a waste to be young): a child regrets still being "young" and not being able to, therefore, serve in the military and because of this being the pride of his mom:

With my backpack, with my jacket, with the feather on my beret, with the sword and the spurs, with the stripe on my trousers, with a cross in the buttonhole, tell me, mother, aren't I handsome?

Look how, under the shining sun, I am all sparkling!

The little wind makes the feather of my beret wave...

Oh my, it is a great waste that I am not truly a soldier!

If I were already a soldier, how many things I'd like to do! Believe, mother great things, unprecedented, miraculous; in a month, badly badly,

I would be made general!

General!...how happy!

All tassels, all silver, to command many soldiers lined up in good order... on horseback, with epaulette...

What a waste being young! ${ }^{19}$.

18 M. Rigotti Colin, Il soldato e l'eroe nella letteratura scolastica dell'Italia liberale, in "Rivista di storia contemporanea", 1985, n. 3, p. 334.

19 G. A. Silvestri, Primissime letture, per gli alunni e le alunne della prima elementare. Parte seconda, compimento al sillabario monosillabico, Torino, Direzione del Giornale L'Unione dei Maestri, 1887, pp. 41-42. 
If we move to the textbooks for the girls' classes, we find the same practical sense found in the boys' books, obviously with other narrative characteristics, but in line with the future adult social roles.

The praise for their gentle heart, the enhancement of the spirit of sacrifice, the strengthening of the maternal sense are added to the recognition of the feminine role in the family, to their pedagogical importance, to the force of feminine virtues. The house is the woman's realm and she exercises an absolute role in the family's affairs; moreover the wellbeing and education of the young children depends exclusively on the maternal cares.

A crucial role is playing by the reading on and the recurring mentions to exemplary women (celebrated women like Cornelia, the Gracchis' mother, Veronica Gambara, Beatrice of Savoia, saint's lives, but also anonymous mothers and women who were nevertheless mentioned for their generous actions) and the more marked distinction between the wealthy child and the poor child with stories and illustrations that more clearly distinguish, compared to what happen in the boys 'books, the diversity in clothing, social environment, games, and one's physiognomy: the girl with the doll in her hand and the girl busy cleaning her home.

It is through this complex of duties that the little Italian boy and girl forge their character and become - or should become - citizens capable of overcoming their "particular", to use De Sanctis' famous words, "moral weakness" that "can become an obstacle in our life if we don't suppress it in our own conscience".

The accomplishment of this objective was dependent on the "fortitude of character" and namely on the internalization of an ethical law invigorated with popular values, sense of duty, achievement in the primary obligations (in first place work and maintaining the family), and supportive participation to the native community. Instruction could not be without education and the true education was the honest and common citizen's one.

\section{The "Maternal" Conception of Italy}

The strong insistence on the personal ethical responsibilities with a clear imbalance in favor of duties with respect to rights was to be read within a double perspective, a geographic and an historical one. It was obviously 
about conveying an image of Italy that to most - unlearned and illiterate, closed within the narrow horizon of an alpine valley or of rural villages based on common farmers' habits, seldom subject to the illiberal propaganda - appeared, as already mentioned, an undefined entity.

Immediately after unification, the Minister of Instruction Francesco De Sanctis and general secretary at the time of Minister Quintino Sella promoted the diffusion of maps of Italy in all schools ${ }^{20}$. The educational iconography of the time often represents a school classroom decorated not only with the king's portrait, but furnished also with an abacus, an alphabet and, a map. If the representation is later than 1880, illustrated posters or some stuffed animals were also frequent in the classroom.

However, it was not only through a map that the sense of belonging to a well defined territorial entity was transmitted. The reading books give us various geographically representations of Italy.

In this case the idea of family is also very common. There is, for example, a "maternal" vision of Italy that almost seems to guard and jealously protect, thanks to her natural morphology (the alpine walls and the seas) her inhabitants by guaranteeing the necessary to their survival with the variety of natural resources (mountains, plains, sea). The principle cities were presented as obedient children of a solicited parent, with Turin and Florence ready to pass the crown to Rome as the first born child. At times, the country was instead described as a bride who demands fidelity. To the father figure corresponded the description of the king who would give the concept of "nation" the solidity and the emotional force of a "great family", overcoming social barriers and geographic peculiarities.

There is, then, a vision that links the "maternal" idea to the enhancement of the regional dimension: people from Piedmont, Lombards, Tuscans, Neapolitans, Sicilians, each with their own characteristics - like the same mother's children with their different temperaments and qualities would work in view of a common goal. The last representation is a vision that we could define passionate (but not elated) antagonistic nationalism: Italians recognize themselves as such because they are different in character and disposition from the French, the Spanish, and the German etc.

20 In 1862 the publishing and photographic bookstore Giovanni Battista Maggi of Turin was asked by the Minister of Public Instruction to produce maps of Italy to distribute in all hallways of the Kingdom's schools, see. G. Chiosso (editor), Teseo. Tipografi e editori scolastico-educativi dell'Ottocento, Milano, Editrice Bibliografica, 2003, p. 334. 
Before unification Italy was represented by the figure of Arlecchino represented in Giusti's poem Lo stivale (the Boot) with the colors of those powerful countries dominating it - with anti-austrian sentiments very evident and openly expressed- ; after unification, the textbooks pointed out with clear satisfaction how now she was well respected within the group of European powers.

The pride for the reached unity was associated to an Italy that by this time reclaimed the right to belong to the great European map, next to great nations such as Great Britain, France, Germany, Russia, and the Habsburg Empire, but above other countries judged as less important like Spain, Portugal, Belgium, Holland, Norway, Sweden, etc.

As far as the historical background was concerned, this was emphasized especially through stories of great events and biographies of men proposed to students as examples of civic virtue and protagonists of noble causes such as benefactors, heroes, explorers, inventors, artists. Among the people who crowded the pantheon of characters proposed to the young students there were Giotto, Dante Alighieri, Pier Capponi, Christopher Colombus, Amerigo Vespucci, Masaniello, Pietro Micca, Alessandro Volta together with representatives of the history of the House of Savoy, in particular Umberto Biancamano, Emanuele Filiberto and Vittorio Amedeo II.

The list of historical figures that crowd books is naturally broader and includes different characters, according to different textbooks. The choices also reflect ideal positions and feelings often felt as antagonist: within Catholic authors/books for example there is a more evident presence of saints and benefactors, in these of secular contents, instead, the protagonists are identified for their civic virtues among others.

However, in all these books there is agreement in representing an historical background in which the protagonists' ethical-pedagogical exemplariness must prevail more than the attempt to ensure, in the few years of compulsory education, an organic conception of the Italian history. A Giovanni Scavia's book that came out in the years of unification, gives precisely the idea of the average Italian man as pictured by the liberal class of those years: Dell'uomo e dei suoi doveri con l'aggiunta di alcuni fatti più notevoli della storia nazionale. (On men and their duties, together with some important events in the national history).

Only with the educational programs of 1888 , the third elementary class would get notions of national history: for the first time, in fact, the legislator feels the necessity to inform these students on "some facts 
regarding the unification of Italy". As a matter of fact, it is only from 1880 that in the normal schools' syllabi - the schools where teachers were trained - the teaching of history with particular reference to the facts and characters of the Risorgimento was included in a more consistent way. As we will indicate below, the 1880s-1890s in Italian educational history represent a significant period for various reasons.

The fil rouge of the country history, the epic of the Risorgimento and the celebration of the splendors of the House of Savoy, are instead themes present above all in the first classes of secondary schools as it is proved by the rapid multiplying of books on "national history for young people" in which were presented the different ideal conceptions and different modalities at the basis of the Italian unification.

The different pedagogical function attributed to history - magistra vitae in the first classes, introduction to a national epic in the following educational courses - was not functional according to the students' age, but it reproduced the idea that at inferior social levels what was necessary to deliver were only strong emotions connected to courage, temperance, civic virtue, heroism, maternal love, sacrifice; these were strong feelings but not sufficient, however, to continue (even if for short time) studies. For these studies, necessary for more significant social roles, it was needed an adequate introduction to that civil philosophy on which the ruling class was laboriously developing the new nation at that time.

Without this work in national education the risk was to have, as Alfani wrote in his book on the Italians' characters, "restless, dangerous and arrogant citizens and not sensible and honest ones" 21 .

\section{Between Self-help and Dreams of National Greatness}

As previously mentioned, in the 1880s-1890s there were relevant changes in the pedagogical and political-educational climate, and as a consequence in the education of the Italian people. In particular, three variants have an important role in the creation of reading books.

21 A. Alfani, Il carattere degli Italiani, Firenze, Barbèra, 1912 ( $1^{\circ}$ ediz. 1876), p. 164. 
The first reinforces the concept of work not only as a duty, but also and in a more insistent way - as an opportunity to improve oneself, especially if accompanied by instruction. It is a topic that in the last decades of the century will become more of a self-help genre. Representatives of this genre are Cantù with his Portafoglio d'un operajo (The worker's wallet); Gustavo Strafforello, Samuel Smiles' traslator; Michele Lessona, author of one of the most read books in Italy, Volere e potere [To wish is to get]; and Carlo Lozzi who invites his citizens to "give with ardor to the conflicts of work and industry" in his book against idleness and laziness.

The praise for "a self made man" goes from Benjamin Franklin - the icon of the Anglo-Saxon self-help - to the great characters in the Italian history, without neglecting the young protagonists of provincial realities who knew how to emerge from their humble origins, overcome local boundaries and become models of achievement and success ${ }^{22}$. The Catholic world, in turn, emphasizes Saint Joseph as an icon of that constant industriousness, that devotion and diligence in work that should have been a qualifying attribute of the good Christian ${ }^{23}$.

This type of "productive" ideology associated with an endless trust in the scientific progress is common, beyond their different political opinions, in intellectuals and scholars, benefactors and philanthropists, priests and freemasons. The praise of the virtuous sobriety in the rural world is joined - and sometimes substituted - by the praise for the working men. In the reading books, (for example in Giovan Battista Cipani's, Primo Macchiati's, and Caterina Pigorini's) there are frequent examples of artisan and industrial work. A work that is always heavy and pain for men, but that can also be a chance for redemption and well-being.

To the celebration of the ethics of work comes often associated the image of the good owner capable of breaking class barriers and of paternalistically exercising an educational influence that manifests itself in the gradual acceptance of the middle classes' values: the care for hygiene, the idea of saving, family propriety, and school attendance. The praise for

22 S. Lanaro, Nazione e lavoro. Saggio sulla cultura Borghese in Italia. 1870-1925, Venezia, Marsilio, 1979, p. 122-124.

23 On the ethis of productive work in the Catholic world see P. Bairati, Cultura salesiana e società industriale, in F. Traniello (editor), Don Bosco nella storia della cultura popolare, Torino, Sei, 1987, pp. 331-357; M. Taccolini (editor), A servizio dello sviluppo. L'azione economic-sociale delle congregazioni religiose in Italia tra Otto e Novecento, Milano, Vita \& Pensiero, 2004. 
the man who can read and write and who, as a consequence, is in the condition to rise along the social ladder, goes hands in hands with the blame for those who are not able to overcome their own misery.

The condemnation of ignorance becomes more insistent and strong. The illiterate is represented as unhappy because he does not have the minimal resources to live in a modern society:

The man, who cannot read and write, is deaf, mute and blind [...] He is deaf because he cannot understand someone else's thoughts, and all that happens around him, is like a mystery. He is mute because he does not know how to conveniently manifest his own thoughts. Lastly he is blind, in his own interests having to leave himself to be guided here and there by others. In few words: the illiterate is everybody's slave, as everybody knows his interests, and often more than he does. ${ }^{24}$

And then painted as disabled destined to social marginality:

Every moment he has the mortification to say: I do not know how to write; if he is best man or godfather he cannot sign; he cannot do anything but make a cross on receipts and documents; his children go to school and he does not understand anything in their books, he cannot see if they are doing well. ${ }^{25}$

In addition, he is exposed to poverty because the job market prefers those who can read, write and count.

The negative counterpoint is represented by accusing vice, the failure caused by the improvident use of money, and the diseases that strike families and wear them out. The tavern, in particular, constitutes a recurring motive of vice and perdition, as emblematically represented in this short story by Ildebrando Bencivenni:

Bartolomeo, while returning home from work one evening, heard happy and loud voices coming out of a tavern, and he decided to enter too. There were many of his companions there, who, as soon as they saw him, invited him to play and to drink. Bartolomeo was a virtuous man. He wanted to refuse, but they asked and begged him so much to stay that he finally agreed to sit down, until at the stroke of midnight he came out drunk and without money. From that time on he liked it and continued to go every evening; until one time playing and drinking, he fought with a rascal. In the heat of the brawl he was stabbed, and fell to the floor wounded. Now he is in the hospital and he will stay for a long time, if he will be lucky enough to heal.

24 P. Fornari, Tomaso o il galantuomo istruito, Torino, Paravia, 1887, pp. 28-29.

25 G. Castrogiovanni, Letture secondo il programma legislative per la terza e quarta classe elementare, Torino, Paravia, 1874, p. 87. 
His poor family is on the rocks, fading with hunger. Here are the sad effects of drunkenness. $^{26}$

The self help culture often connects the misfortunes to men's foolishness and their lack of prudence. These motives, together with the theme of the "heart" and of reciprocal social responsibilities, on the wake of De Amicis' novel, not only fill the stories' and the popular novels' pages, but also the reading books' ones.

These motives are presented along two main narrative schemes: the one with a tragic ending with the goal of intimidating the little reader and of suggesting doing good (starting from skipping the school till going to jail); and the one with happy endings that favor, according to a proven tradition, the educational force of a good example.

Much of the self-help theme - in the end - is inspired by a criticism of the Italian custom and focused in denouncing the weaknesses of the new united reality, if compared with what is happening in other more evolved nations. In this comparison, it is possible to find some motives of the change that also in the school books marks the evolution from a vision of the country as extension of the native place and the family life to the idea of a nation with a specific identity and in search of its own critical space.

The second variant regards the teaching of history and geography that the programs of 1888 authorized starting from the third class with explicit reference to the knowledge of the main facts linked to the national unification and the geographic reality of Italy. It is about an important novelty that deals, in particular, with the passage of an historical teaching from having ethic-pedagogic goals to political-dynastic-nationalistic goals.

It is about a passage anticipated and documented by the editorial events regarding Giannetto following unification. The feeling of belonging to a country, initially placed at the intersection between belonging to the birth place and the sharing of the more immediate affections -family and friends-, is integrated and reinforced by the presentation of the Risorgimento as the result not only "of self-sacrifice, courage and the martyrdom of patriots, volunteers, soldiers", but also "of the generous work the Savoy House has done for the Italian cause"27.

26 I. Bencivenni, Il libro completo per gli alunni e le alunne della terza classe elementare completamente adattato agli ultimo programmi legislativi, Torino, Tarizzo, 1892, p. 18 (1. edition 1880).

27 L. Pazzaglia, I libri di testo: il caso del Giannetto di Parravicini, in P.-L. Ballini,G. Pécout (editors), Scuola e Nazione in Italia e in Francia nell'Ottocento. Modelli, 
If the pages dedicated to historical and geographic themes (in particular to exemplary biographies) are reduced in light of the making History and Geography as separate topics, at the same time, the publication of small history and national geography booklets is increased. As a matter of fact, in the ten years following the new norms of 1888, hundreds of history and geography texts respectfully are in fact produced.

The institutional passage that attributes more space to historical and geographic teachings in the construction of the Italian identity at the elementary school is accompanied, in turn, by an evolution of geographic teaching - this is the third variant - not more blocked within a maternal and regionalist perspective of Italy. The motive of the white man's superiority with respect to other races begins actually to make its appearance.

The presentation of Europe as the continent that for civil, cultural, economic and moral development is superior to others and capable of civilizing those areas inhabited by populations judged as barbaric, savage, crude, idolatre, is associated with the development of the Italian nation. The anthropological model is that of the white man: active, industrious, laborious, not corrupted morally, as described in the seventh century canon by the German anthropologist Johann Friedrich Blumenbach, considered the father of the scientific racism and of craniology.

Among the religious beliefs, Christianity is described as the religion of civility and charity. Europeans are also more advanced in political and social life unlike the "savage ethnic groups" organized in primitive associations, tribes and clans, with means of support, clothes and homes that recalled the way of living that the "civil" people had in prehistoric times.

In the reading books, besides in history and geography texts, these factors were adopted to convey a strong sense of pride based on the sense of belonging to a powerful and culturally developed nation. Starting from the programs of 1888 and after, the good citizen is the Italian man who is more knowledgeable about the values of the Risorgimento, conceived in terms of civility, greatness and national glory.

The feelings of the Third Italy permeate also the hearts of the youngest Italians as suggested by Minister Baccelli's notes about the programs of 1894:

pratiche, eredità. Nuovi percorsi di ricerca comparata, Venezia, Istituto Veneto di Lettere, Scienza ed Arti, 2007, p. 178. 
I have created a single group with history, geography, rights and duties to indicate, even in a visible way, that the three teachings must in good harmony contribute to the goal of making one love the country, of awakening the conscience and warming up the feeling of Italian spirit...From the knowledge of men and facts about the national Risorgimento, the boy will know more about the previous ages, the most notable events and the men most deserving of human civility, to learn how, in an interrupted succession of philosophies and works, the heredity of a great nation with Rome as capital was transmitted to us. ${ }^{28}$

Naturally the passage from a maternal Italy to the celebration of an ancient greatness was not new to the dreams cultivated by Dogali and after. The destiny of the Great Italy could not have remained closed within its borders, but needed to aim toward power and expansion.

\section{Bibliography}

M. Bacigalupi, P. Fossati, Da plebe a popolo. L'educazione popolare nei libri di scuola dall'Unità d'Italia alla Repubblica, Scandicci, La Nuova Italia, 1986.

P. Bairati, Cultura salesiana e società industriale, in F. Traniello (editor), Don Bosco nella storia della cultura popolare, Torino, Sei, 1987.

A. Barausse, Il libro per la scuola dall'Unità al fascismo. La normativa sui libri di testo dalla legge Casati dalla Riforma Gentile (1861-1922), Macerata, Alfabeta Edizioni, 2 voll., 2008.

E. Becchi, D. Julia (editors), Storia dell'infanzia, Vol. 2., Dal Settecento a oggi, Roma-Bari, Laterza, 1996.

P. Boero, C. De Luca, La letteratura per l'infanzia, Torino, Einaudi, 2009.

E. Catarsi, Storia dei programmi della scuola elementare (1860-1985), Firenze, La Nuova Italia, 1990.

G. Chiosso (editor), Teseo. Tipografi e editori scolastico-educativi dell'Ottocento, Milano, Editrice Bibliografica, 2003.

T. De Mauro, Storia linguistica dell'Italia unita, Roma-Bari, Laterza, 2008.

S. Lanaro, Nazione e lavoro. Saggio sulla cultura Borghese in Italia. 1870-1925, Venezia, Marsilio, 1979.

28 E. Catarsi, Storia dei programmi, cit., p. 201. 
L. Pazzaglia, I libri di testo: il caso del Giannetto di Parravicini, in P.-L. Ballini,G. Pécout (editors), Scuola e Nazione in Italia e in Francia nell'Ottocento. Modelli, pratiche, eredità. Nuovi percorsi di ricerca comparata, Venezia, Istituto Veneto di Lettere, Scienza ed Arti, 2007.

M. Rigotti Colin, Il soldato e l'eroe nella letteratura scolastica dell'Italia liberale, in "Rivista di storia contemporanea", 1985, n. 3, p. 334.

S. Soldani, La nascita della maestra elementare, in S. Soldani, G. Turi (editors), Fare gli Italiani. Scuola e cultura nell'Italia contemporanea, Bologna, Il Mulino, 1993, vol. I, pp. 89-90.

M. Taccolini (editor), A servizio dello sviluppo. L'azione economic-sociale delle congregazioni religiose in Italia tra Otto e Novecento, Milano, Vita \& Pensiero, 2004.

G. Talamo, La scuola. Dalla legge Casati alla inchiesta del 1864, Milano, Giuffré, 1960. 